NBER WORKING PAPER SERIES

\title{
THE EFFECTS OF THE COLOMBIAN TRADE LIBERALIZATION ON URBAN POVERTY
}

\author{
Pinelopi Koujianou Goldberg \\ Nina Pavcnik \\ Working Paper 11081 \\ http://www.nber.org/papers/w11081
}

\author{
NATIONAL BUREAU OF ECONOMIC RESEARCH \\ 1050 Massachusetts Avenue \\ Cambridge, MA 02138 \\ January 2005
}

This paper was prepared for the NBER Globalization and Poverty Conference, Cape Cod, September 10-12, 2004. We are grateful to Eric Edmonds, Ann Harrison, and Chang-Tai Hsieh for helpful comments. This research was in part supported by funding from the National Science Foundation Grant SES \#0213459. The views expressed herein are those of the author(s) and do not necessarily reflect the views of the National Bureau of Economic Research.

(C) 2005 by Pinelopi Koujianou Goldberg and Nina Pavcnik. All rights reserved. Short sections of text, not to exceed two paragraphs, may be quoted without explicit permission provided that full credit, including () notice, is given to the source. 
The Effects of the Colombian Trade Liberalization on Urban Poverty

Pinelopi Koujianou Goldberg and Nina Pavcnik

NBER Working Paper No. 11081

January 2005

JEL No. F10, F13, J31

\begin{abstract}
We examine whether the Colombian trade reform can explain any of Colombia's decline in urban poverty between 1984 and 1995. Our approach focuses on short- and medium- run channels through which trade reform could affect poverty. Despite the chronological coincidence of the poverty reduction with the trade reforms over this period, we do not observe any evidence of a link between poverty and tariff reductions operating through the labor income channel. Our descriptive analysis suggests that although poverty is predominately concentrated among individuals living in households with unemployed head, it is non-negligible among the employed and especially those working in the informal sector and those paid below minimum wage. Industry affiliation also plays a role. However, we find no evidence that the trade reforms reduced poverty via any of the above variables in a significant way. We cannot rule out the possibility that trade liberalization has contributed to the poverty reduction through general equilibrium effects, and in particular through its potential role in lowering the prices of goods consumed primarily by the poor.

Pinelopi Koujianou Goldberg

Department of Economics

Yale University

37 Hillhouse Avenue

P.O. Box 208264

New Haven, CT 06520-8264

and NBER

penny.goldberg@yale.edu

Nina Pavcnik

Department of Economics

6106 Rockefeller Center

Dartmouth College

Hanover, NH 03755

and NBER

nina.pavcnik@dartmouth.edu
\end{abstract}




\section{Introduction}

The recent wave of trade reforms in the developing world has been followed by an intense debate as to whether these reforms contributed to the increase in wage inequality observed in many developing countries during this period. While this debate has not delivered a unanimous answer, free trade advocates emphasize that even if trade liberalization increased inequality (thus worsening the relative position of some groups in the population), it may still have improved the absolute position of the entire population, thus reducing poverty. Proponents of this view accordingly advocate a shift of focus from relative to absolute measures of wellbeing.

Despite the importance of the above argument, there has been little work on the effects of trade policy on absolute measures of well-being, such as poverty. The scarcity of studies on this topic is primarily due to the difficulties associated with the measurement of poverty on one hand, and the identification of the trade policy effects on the other. The present paper takes a step towards filling this gap. While our analysis faces many of the challenges encountered in previous attempts to establish a link between trade liberalization and poverty reduction, we believe that the importance of the issue from a public policy point of view justifies the attempt to more closely study this link.

Our analysis focuses exclusively on the urban sector in Colombia, a country that underwent major unilateral trade liberalization in the late 1980's and early 1990's following its 1981 accession to the GATT/WTO. The focus on the urban sector is dictated by the nature of the policy experiment we exploit to identify the relationship between openness and poverty reduction. The drastic tariff and non-tariff barrier reductions between 1985 and 1992 were concentrated in the manufacturing sector, which is mainly located in urban areas. The average tariff in manufacturing dropped from 50 to 13 percent between 1984 and 1998; in contrast, the average tariffs in agriculture declined substantially less, from 26 to 12 percent. Given the relatively small magnitude of trade liberalization in rural areas, we do not expect the reforms to have had as significant of an impact on rural poverty, at least not in the short- or medium-run. Furthermore, the wide use of domestic production and export-oriented agricultural policies by developed countries suggests that agricultural prices in the developing world would be 
potentially affected more by a multilateral liberalization of agricultural trade, such as the one currently debated in the Doha WTO negotiations, than a unilateral trade liberalization episode in a single country. Hence, while poverty is particularly problematic in rural areas, we confine our analysis to the urban sector. According to World Bank estimates, poverty rates in urban Colombia lie well above the poverty rates in developed countries, even though they are consistently lower than in rural areas. ${ }^{1}$

Methodologically, we rely on a partial equilibrium approach to identify the link between poverty and trade liberalization in the short- or medium-run. To be more specific, we focus on the effects of trade liberalization on urban poverty via the labor income channel. We examine whether the trade reforms led to changes in employment conditions and wages in the short- to medium- run, which may have affected poverty. The obvious shortcoming of this approach is that we are not able to deliver an overall assessment of the effect of trade liberalization on poverty. By focusing on the labor income channel, we abstract from the effects that trade policy may have had on poverty through the consumption or household production channels. ${ }^{2}$ Given that trade policy affects goods prices, and that both consumption and household production decisions are a function of these prices, these channels are potentially important. This is demonstrated for example in two recent studies that have adopted a general equilibrium approach to assess the poverty effects of trade reforms (Porto (2004) and Chen and Ravallion (2004b)).

In addition, we potentially ignore one of the most important channels through which trade may affect poverty, namely growth. There is fairly robust evidence that growth reduces poverty (see Ravallion (2004), pp. 5-6 and Figure 2) in the long run. However, the relationship between openness and growth has been more contentious. Given that establishing a clear link between free trade and growth has been empirically elusive (see Hallak and Levinsohn (2004), Winters et.al (2004) for recent overviews), there is little hope that one could credibly demonstrate a relationship between free trade and poverty via the growth channel, especially since the growth effects of trade liberalization likely spread over several years.

\footnotetext{
${ }^{1}$ In particular, the 2002 World Bank Poverty Assessment report for Colombia reports a poverty rate of 55\% for the urban sector in 1999 , while the poverty rate in the rural sector is $79 \%$. The national poverty rate is reported at $64 \%$. The corresponding numbers for the "extreme" poverty rate in 1999 are $14 \%, 37 \%$, and $23 \%$ respectively. We discuss the precise definitions of these poverty rates and their measurement in section 4.1.

${ }^{2}$ For a discussion of the channels through which trade liberalization affects poverty see Goldberg and Pavcnik (2004b), and Winters, McCulloch and McKay (2004).
} 
On the positive side, the partial equilibrium approach does not require the strong assumptions inherent in the general equilibrium framework (see Goldberg and Pavcnik (2004b), pp. 39-40) for a detailed discussion. Furthermore, the partial equilibrium approach allows us to link poverty (or at a minimum some of the variables that are highly correlated with it) to trade liberalization using plausibly exogenous variation in trade policy over time, so that identification of the pure trade policy effects is arguably more compelling. Finally, there is still little known about the short- and medium-run effects of trade reforms. Given that the adjustment costs associated with trade liberalization are potentially high, a study of the short- or medium-run effects is important from a policy point of view, especially since the negative stance towards free trade is often attributed to the negative effects that reforms are expected to have in the short run.

Our analysis proceeds as follows. We start by providing a brief overview of the policy experiment and the data we exploit in our empirical analysis. Next, we discuss how we measure poverty and compare our poverty measures to those used by the World Bank and Colombian policymakers. Based on these measures we then describe who is poor in urban Colombia. The purpose of this exercise is to establish whether poverty is correlated with particular conditions (e.g., unemployment, employment in sectors that experienced large tariff cuts, work in the informal sector, compliance with minimum wages, etc.) that are likely to be affected by trade liberalization. If it is, then the next step in the analysis is to examine whether the trade reforms did indeed have an impact on these conditions. The advantage of this step-by-step approach is that it allows us to infer not only whether trade liberalization had an impact on poverty, but also the specific channels through which this impact was realized. Finally, in the last step of the empirical analysis, we make an attempt to directly relate our poverty measures among the employed to trade liberalization, in order to assess the overall effect of the trade reforms on urban poverty via the labor income channel.

To preview our results, we find strong and robust evidence that urban poverty is highly correlated with certain conditions such as unemployment, employment in the informal sector, and wages below the minimum wage standard. However, we find little to no evidence that any of these conditions were affected by the recent trade liberalization in a significant manner. Perhaps not surprisingly, we then also fail to find any direct correlation between poverty and trade reforms in urban Colombia using partial equilibrium approach. While it is premature to draw any general conclusions regarding the relationship between trade liberalization and poverty in 
developing countries based on a single country study, our results seem to point to growth and general equilibrium effects as being potentially more important in reducing poverty.

\section{The Policy Experiment: The Colombian Trade Liberalization}

Starting in 1985 Colombia experienced gradual trade liberalization that culminated in 1990-91. As we have argued in our earlier work ${ }^{3}$, several features of this trade liberalization episode make it attractive from an empirical point of view.

First, because Colombia had not participated in the tariff-reducing negotiation rounds of the GATT/WTO ${ }^{4}$, it used tariffs as one of the primary trade protection tools prior to the reforms. A big part of the Colombian trade liberalization consisted of reducing tariffs to levels comparable to those observed in other WTO members. The main advantage of tariffs relative to non-tariff barriers to trade (NTBs) as a measure of trade policy is that they are easy to measure and comparable across years. ${ }^{5}$ NTBs were also reduced as part of the reforms. Unfortunately, industry level information on NTBs is not consistently available on an annual basis. Fortunately, the existing data suggest that tariff levels (and their changes) are positively correlated with NTB levels (and their changes), so that tariff changes are likely to provide fairly accurate measures of the overall trade policy changes (albeit the coefficients on tariffs in our regressions might overstate the pure tariff effect). ${ }^{6}$

A second appealing feature of the Colombian trade reforms is that they affected not only the average level of protection, but also its structure. Indicatively, while the correlation of industry tariffs between 1984 and 1986 was 0.94, the correlation between 1984 and 1992 (a year following the peak of trade reform activity) was only 0.55 . The changing structure arises from the fact that the reforms had a differential impact on each sector: sectors with initially high

\footnotetext{
${ }^{3}$ See Attanasio, Goldberg and Pavcnik (2004), and Goldberg and Pavcnik (2003, 2004a) for a detailed description of the reforms, and tables and figures with descriptive statistics on the tariff and non-tariff barrier reductions.

${ }^{4}$ Colombia became a GATT member in 1981, but chose to make use of the developing country exemption regarding tariff cuts (article XVII of GATT).

${ }^{5}$ In particular, NTBs are measured by coverage ratios, which are notoriously problematic measures of the trade restrictiveness of NTBs.

${ }^{6}$ One could alternatively rely on effective rates of protection as a measure of trade policy. Unfortunately, effective rates are available for only a few years. In Goldberg and Pavcnik (2004a), we discuss that the correlations between nominal and effective rates are high in years when the information on both is available. This suggests that the results would be robust to using effective rates.
} 
levels of protection (such as textiles and apparel) experienced the largest tariff cuts; in contrast, in sectors with lower pre-reform protection levels, the tariff cuts were more modest. It is this cross-sectional variation in tariff reductions that we exploit in order to identify the trade policy effects. In addition, this change in the trade protection structure was accomplished over the course of several years, which provides ample variation over time in the data for the purpose of identifying the trade policy effects.

Finally, because the main objective of the Colombian government was to bring industry tariffs to an almost uniform level in accordance with WTO guidelines, policymakers were less prone to succumb to industry pressure or lobbying. This implies that tariff changes can be plausibly considered exogenous.

These features of the Colombian trade reforms suggest that the cross-sectional variation in tariff changes provides an appealing policy experiment to study how trade policy changes have affected the Colombian economy. There are however two potential caveats associated with such an exercise. First, while tariff changes arguably provide accurate measures of the recent liberalization in Colombia, the "opening" of the Colombian economy might have also affected other trade-related variables that are not captured by tariffs. To address this concern we exploit changes in industry imports and/or exports over time as additional measures of exposure to trade. The use of quantity measures such as imports and exports is naturally controversial as such variables are endogenous to trade policy changes. ${ }^{7}$ The advantage of using them is that any changes in trade policy that we may have missed by exclusively focusing on tariffs will likely lead to changes in the import and export volumes so that these variables may more accurately represent the cumulative effect of trade policy changes. Along the same lines we have considered including foreign direct investment (FDI) in the analysis, especially as there is strong evidence that FDI has had strong distributional effects in Mexico (see in particular Feenstra and Hanson (1996, 1997)). Unfortunately, FDI data are not available for Colombia at the industry level. However, FDI inflows in Colombia have been small relative to Mexico, so that it is unlikely that they have had any significant impact on the labor market.

The second caveat is that the cross-sectional variation of tariff changes is only useful to the extent that we study outcomes that are likely to differ by industry (e.g., industry employment,

\footnotetext{
${ }^{7}$ To alleviate these endogeneity concerns we employ lagged values of imports or exports rather than their current values.
} 
wages, etc.). This is precisely the reason that we focus on partial equilibrium effects of trade policy changes. We abstract from economy-wide implications of tariff policy changes, because, while there is no doubt that economy-wide effects are important in the general equilibrium, we do not have a way of separating these trade-induced effects from other economy-wide shocks without imposing strong identification assumptions.

\section{The Household Survey Data}

Our ultimate empirical goal is to link the trade policy changes described above to poverty measures, or to economic variables that are highly correlated with poverty. To construct these variables we rely on the June waves of the Colombian National Households Survey (NHS), which are administered bi-annually by the Colombian National Statistical Agency (DANE). We focus on the June waves because these waves include a special module on the informal sector of the economy (defined as the sector that does not comply with labor market regulations). Given that informal sector account for 50 to $60 \%$ of urban employment and given that informality is apriori likely correlated with poverty, including information on those employed in the informal sector in a study of urban poverty is particularly important. To construct poverty measures we rely on the income information provided in the NHS. While expenditure survey data may be preferable for measuring poverty, the household expenditure survey in Colombia is available for only one year, so that it is not possible to analyze the evolution of poverty using the expenditure data.

Our data cover urban areas in the years 1986, 1988, 1990, 1992, 1994, 1996, and 1998. This 14-year period covers several trade liberalization episodes. We construct several variables that control for household and individual demographics such as age, gender, marital status, family size, whether a person is a household head, education, literacy, geographical location, whether a person was born in urban area, and how long the person has resided in current residence. Based on the information on highest completed grade, we classify individuals into those with no complete schooling, complete primary school, complete secondary school, and complete university degree. 
In addition, the survey contains detailed information on employment characteristics and wages. Individuals who are older than 11 are classified into 3 categories: inactive ${ }^{8}$, unemployed, and employed. For all categories, the NHS reports income from sources other than earnings. For unemployed individuals, the survey reports the 1-digit ISIC code of the industry in which the individual used to work, and the industry in which they are looking for new work. There is a total of 9 1-digit ISIC industries.

For those who are employed, the survey reports earnings, occupation, type of employer (i.e., private company, government, private household, self-employed, unpaid family worker), and the 2-digit ISIC code of the industry in which the individuals are employed. There is a total of 33 2-digit ISIC industries per year. ${ }^{9}$ Based on the information on the reported earnings and the number of hours worked normally in a week, we construct hourly and monthly wages. We also create controls for whether an individual works for a private company, government, or a private household, and whether he/she is an employer or self-employed. Furthermore, the survey reports whether the worker's employer contributes to their social security fund. The employer's compliance with the social security legislation (and thus labor market regulation) provides an excellent indicator for whether a worker is employed in the formal sector. Finally, based on the information on monthly minimum wage standard, we generate an indicator for whether a worker's monthly earnings are below minimum wage standard. ${ }^{10}$

The main disadvantage of our data is that we do not have information on unionization. However Edwards (2001) and anecdotal evidence suggest that unions do not have significant power in most Colombian industries (with the possible exception of the public sector and the petroleum industry).

\section{Who Is Poor in Urban Colombia}

\subsection{Measurement of Poverty}

(a) Poverty lines

\footnotetext{
${ }^{8}$ DANE classifies individuals ages 12 and older as inactive if they are not employed, and are not actively seeking work. The primary activity of inactive individuals is usually being a student, a homemaker, or a pensioner.

${ }^{9}$ We have tariff information for 21 of these industries (albeit tariffs are likely zero in the industry categories for which no tariffs are reported (i.e. services)).

${ }^{10}$ Information on monthly minimum wages is from Maloney and Nunez (2003).
} 
An operational definition of poverty presents many conceptual and measurement problems (see Ravallion (2004) for a detailed discussion). One of the most important ones is the distinction between absolute and relative poverty. In the first case, the measurement of poverty relies on a poverty line that has a fixed real value - the “\$1 per day” poverty line at 1993 Purchasing Power Parity, which is representative of poverty lines used in poorest countries, provides an example of such as fixed line. In contrast, the measurement of relative poverty relies on a line that increases with the mean income. The two measures have very different implications for the assessment of the impact of trade reforms on poverty. To see why, consider the extreme case in which the (relative) poverty line moves proportionately with mean income. A trade policy that raises all incomes by the same proportion will in this case leave relative poverty unchanged. Still, the policy has raised - in absolute terms - the incomes at the bottom of the income distribution, reducing the (absolute) poverty of the lowest-income individuals.

We focus on absolute poverty for several reasons. First, the value judgment underlying the use of the relative poverty line is that well-being should be measured in relative terms only. This view seems extreme, especially when applied to low- or middle-income developing countries such as Colombia; while relative standing is certainly important for welfare, it is hard to argue that absolute standards of living are irrelevant in a country like Colombia. Second, when a relative measure of poverty is adopted, the question of how trade policy has affected poverty becomes equivalent to the question of how trade policy has affected inequality. The latter question has been researched extensively in the literature - see for example, Attanasio, Goldberg and Pavcnik (2004) for a detailed analysis of how the trade reforms have affected inequality in Colombia. However, the existing literature has mostly abstracted from the link between absolute poverty and trade policy.

Obviously, any measure of absolute poverty depends crucially on the setting of the fixed poverty line. DANE calculates its own poverty line based on some minimum calorie and nutrition requirements for an individual of average age. Urban poverty lines differ across cities. DANE further distinguishes between two poverty lines: the "extreme" poverty line, and the regular poverty line, which according to the World Bank is 2 to 2.5 higher than the extreme one (see World Bank (2002), p. 100 for a detailed description).

Unfortunately, DANE does not make its poverty data publicly available, while the World Bank (2002) reports DANE poverty lines only for selected years. Moreover, it is not clear whether the 
consumption basket used in the DANE poverty calculations remains fixed over time; a changing consumption basket would complicate comparisons of poverty across years even further. For these reasons, we decided to adopt the "international” poverty lines that are based on multiples of the \$1 per day (in 1993 PPP terms) measure. Details on how this line was chosen are provided in Chen and Ravallion $(2001,2004 a)^{11}$. In the context of Colombia, this line will be expressed in 1995 Colombian pesos.

To make sure that our empirical results are not due to the particular choice of the poverty line, we consider several multiples of the $\$ 1$ per day measure (\$2; \$3; \$4; \$5; ) and conduct extensive sensitivity analysis. In addition, we compare individuals in the bottom 10\% and 20\% of the per capita income distribution in urban Colombia in 1986 to those who fare better. The income for the bottom $10 \%$ of the income distribution lies somewhere between the \$2 and \$3 poverty line; for the bottom $20 \%$ of the income distribution, the income is between $\$ 3$ and $\$ 4$ per day. Overall, we consider 8 distinct measures of poverty (6 measures based on multiples of the \$1 per day line, and 2 measures based on the income distribution). These measures should cover the entire spectrum of plausible poverty measures.

\section{(b) Household Income Per Person}

Household income is measured in the NHS on a monthly basis as the sum of the incomes of all individuals in the household. Income of employed individuals consists of reported wages or earnings from self-employment. The earnings of individuals who work as unpaid family workers are set to zero. In addition, the survey asks all individuals older than 11 (irrespective of their employment status) whether they have received income from other sources (such as interest payments, dividends, rents, pensions, public assistance, etc.). All monetary values are expressed in 1995 pesos.

To obtain per capita household income we adjusted the household income by the number of household members. To this end, we experimented with two alternative adult-equivalency formulas:

(i) The first one follows Deaton and Paxson (1997) who compute adult equivalency as $\left(N_{a}+\alpha N_{c}\right)^{\theta}$, where $N_{a}$ is number of adults in a household, $N_{c}$ is number of children

\footnotetext{
${ }^{11}$ Following Chen and Ravallion, we actually use the \$1.08 per day (in 1993 PPP terms) line and its multiples, though this line is usually referred to as the “\$1 per day" poverty line.
} 
(defined as individuals ages 15 or less), $\alpha$ is adult equivalency scale and $\theta$ is an economies of scale parameter. $\alpha$ and $\theta$ can take on the values $1, .75, .5$. This yields nine measures of per capita household income. This is the formula most commonly used in developing countries, though there is no consensus on the particular values of the parameters $\alpha$ and $\theta$.

(ii) The second one is the OECD formula for adult equivalence: $1+.7\left(N_{a}-1\right)+.5 N_{c}$ (based on World Bank Poverty Manual (online document, page 21).

Because there is little agreement in the development literature as to which equivalency formula is more appropriate, we have computed per capita income based on alternative equivalency and scale parameters, and examined the correlations across these alternative definitions. The results are reported in Table A.1 in the Appendix and suggest that alternative measures of per capita income are highly correlated, with the correlations ranging from 0.92 to 1 . In general, the income measures seem more sensitive to changes in the scale parameter $\theta$ than changes in the adult equivalency parameter $\alpha$. As a further robustness check we have also computed poverty headcount ratios using the $\$ 1$ and $\$ 2$ per day measures for alternative adult equivalency formulas. The results are presented in Table A.2 in the Appendix. While the exact headcount ratio varies with the values of $\alpha$ and $\theta$ (as with Table A.1 the estimates are more sensitive to the economies of scale parameter than the adult equivalency parameter), the time trends regarding the evolution of the poverty headcount ratios are similar across alternative per capita income definitions. Hence, it is unlikely that different income measures will yield different conclusions regarding the effects of trade policy on poverty.

Given the high correlation coefficients across income definitions in Table A.1 and the similar time trends in the poverty headcount ratios, we chose to focus on a per capita income measure based on $\alpha=1$ and $\theta=1$ (in other words simple per capita household income without any adult-equivalency adjustment) for the rest of the analysis. This is consistent with the approach taken in Chen and Ravallion (2001, 2004) and the World Bank Poverty Report (2002).

\section{(c) Poverty Headcount Ratios}


Based on the per capita income measure discussed above we computed various poverty

headcount ratios, each corresponding to a different poverty line. ${ }^{12}$ Our estimates are displayed in Table 1.

To assess whether the numbers in Table 1 appear reasonable, we compared the headcount ratios we obtained based on the \$2 per day measure to those reported by the World Bank using the same measure (World Bank (2002), Table 2, p. 12). Our estimates seem very close to those reported by the World Bank. ${ }^{13}$

Table 1 exhibits several interesting features. First, note that the poverty rates based on the \$1 per day measure are extremely small. This is not surprising given that Chen and Ravallion suggest that the $\$ 1$ line is indicative of poverty lines used in poor countries, and not of middleincome countries such as Colombia. Second, while the \$2 per day line is presumably more appropriate for Colombia, note that the poverty rates computed based on this line are still well below the poverty rates reported by the World Bank based on DANE poverty lines. This suggests that the standard of living considered acceptable by Colombians is substantially higher than the one corresponding to the $\$ 2$ per day measure. The urban poverty rates computed by the World Bank based on DANE poverty lines (available for selected years only in the World Bank Poverty Report (2002, Table 2, p. 12)) are displayed at the bottom of Table 1. A comparison of these rates to the ones we have computed based on multiples of $\$ 1$ per day poverty lines suggests that the extreme poverty rate corresponds roughly to a definition of poverty that uses the \$3 per day measure as the poverty line; the regular poverty rate corresponds roughly to the definition that uses the $\$ 7$ per day measure. It is worth noting that these poverty lines, which are

\footnotetext{
${ }^{12}$ People often rely on measures of household expenditures from consumer expenditure surveys rather than income to compute poverty rates. To our knowledge, such information is only available for one year during our time frame in Colombia.

${ }^{13}$ In particular, for 1988 we estimate the poverty rate based on the $\$ 2$ per day measure to be $5.7 \%$, while the World Bank reports a figure of 5\% for the same year. The World Bank estimate for 1995 is 3\%. While we do not have data for that particular year, our estimates for 1994 (3.7\%) and 1996 (5.5\%) seem in line with their estimates. Similarly, we do not have data for 1999, but our poverty estimate for 1998 (7.3\%) is roughly in line with the World Bank estimate of 5\% for 1999. Overall, it seems that our estimates are slightly higher than those reported in the World Bank report, but given that the World Bank uses a different wave of surveys (September instead of June), and that the years they use in their calculations differ from those we have available in our survey waves, the numbers seem to match up quite well.
} 
viewed as the appropriate benchmarks by Colombian policymakers, suggest that poverty is still substantial in urban areas ${ }^{14}$.

A final feature of Table 1 worth noting is that even though the magnitudes of poverty rates differ depending on what poverty lines we use, they all exhibit similar time trends. In all cases, poverty steadily declines between 1984 and 1994 and rises thereafter. Hence, it seems safe to conclude that no matter what poverty definition we adopt, our empirical results concerning the effects of trade policy on poverty will not depend on the particular choice of the poverty line.

\subsection{Descriptive Results: Who is Poor}

Before investigating the relationship between trade policy and poverty, we use the household survey data to describe which households are most affected by poverty. Correlations between poverty and various demographic and employment-related characteristics can give us a preliminary idea as to how likely it is that trade policy has had an impact on Colombian urban poverty.

Table 2a presents the fraction of individuals classified as poor in 1986 by the following characteristics of household head: employment status; education; age; and gender. As with our earlier tables, the magnitudes of the poverty rates differ depending on the poverty line used in the calculations, but the comparisons across different household groups exhibit the same patterns. We therefore focus most of our discussion on the \$3 per day measure.

The most interesting pattern emerging from Table 2a is that poverty is highly correlated with unemployment. For example, for the \$3 per day measure, our calculations suggest that 47.7\% of individuals living in households with an unemployed household head are poor; for the $\$ 7$ per day line this proportion is as high as $81.4 \%$. Clearly, one cannot contemplate a poverty reduction in urban Colombia without addressing the issue of unemployment.

Having said that, it is worth noting that even among the employed, the poverty rates are not negligible. The \$3 per day line implies that 14\% of individuals living in households with an employed household head live in poverty; if one uses the $\$ 7$ per day line as the benchmark, as

\footnotetext{
${ }^{14}$ These estimates are also in line with Porto’s (2004) poverty numbers for Argentina, which imply extensive urban poverty when the internal Argentinean poverty line is used, especially in the period covering the Argentinean financial crisis.
} 
Colombian policymakers do, then the poverty rate among the employed becomes 53\%. These are sizeable numbers!

The patterns revealed in Table 2a are also evident in Table 2b, in which we examine the same correlations in a regression framework; this allows us to obtain correlations between poverty and employment-related variables conditional on demographics such as education, age, etc. Consistent with the results based on the unconditional means in Table 2a, the estimates indicate that lack of education is associated with a higher probability of being poor. More importantly, we again find that even conditional on education, poverty is highly correlated with unemployment (inactive is the base group). A comparison of the R-squares from regressions with and without employment indicators further suggests that employment status (i.e., employed, unemployed, inactive) has substantial explanatory power. For example, conditional on demographic and educational indicators, employment indicators account for $3.1 \%$ of the overall variance in poverty and $29 \%$ of the explained variance in poverty in the case of $\$ 3$ a day poverty line.

As noted earlier, poverty rates among the employed are not negligible either. We therefore turn our attention to poverty among individuals living in households with an employed household next. Which demographics and employment characteristics of such households are correlated with poverty? This question is addressed in Tables 3a and 3b. As before we present our results both as unconditional correlations (Table 3a), and in a regressions framework that conditions on various demographics (Table 3b).

First, the results in Table 3a suggest that poverty rates vary by industry of employment: at the 1-digit ISIC level, construction, and wholesale and retail trade are associated with the highest poverty rates. Using the $\$ 3$ per day line, we find that $19 \%$ and $18.4 \%$ of individuals living in a household where the household head is employed in these two sectors respectively live in poverty; financing, insurance and business present the lowest poverty rates (7\%), while manufacturing is somewhere in the middle (11.5\%). A further breakdown of employment by 2digit ISIC code shows that poverty rates also vary across 2-digit ISIC codes. This variation is likely to be relevant for the assessment of the effects of trade policy on poverty; if tariff reductions are disproportionately concentrated on industries with higher poverty rates, leading to a decline in relative prices and potentially wages in these sectors, then trade liberalization may have adverse effects on poverty in the short run. 
Second, no matter what poverty definition one adopts, poverty rates are substantially higher for individuals living in households where household head works in the informal (rather than the formal sector). Third, a wage below the minimum wage standard is an excellent predictor of poverty: $41 \%$ of individuals living in a household where the household head is paid below the minimum wage live in poverty (according to the $\$ 3$ per day line). ${ }^{15}$ While this is not surprising (obviously a poverty definition based on an income measure will be highly correlated with wage-related variables), it serves as a confirmation that individuals receiving minimum wages in their primary employment do not have other sources of income that would considerably improve their financial situation. Finally, poverty depends on the type of employer: unpaid family workers and members of their household are most likely to be poor, while government employees fare the best.

These empirical patterns are confirmed in the regression analysis conducted in Table 3b. The table reports results from regressions based on the $\$ 3$ per day and $\$ 4$ per day poverty lines respectively; additional results, based on alternative poverty definitions can be found in the Appendix tables A.3a, A.3b, and A.3c. Apart from confirming the robustness of the aforementioned correlations, the regression results allow us to assess the explanatory power of various characteristics of employed household head in explaining poverty. First, the 2-digit ISIC industry indicators (retail is the omitted one) are jointly significant. Comparisons of the Rsquares across specifications that do, and do not include industry indicators suggest that, conditional on demographic characteristics, industry indicators account for $1.5 \%$ of the overall variance and $14 \%$ of the explained variance in poverty among households with employed heads. These regressions suggest that industry affiliation is correlated with poverty. Thus, if trade policy affects industry wages and trade policy changes differed across industries, the reforms may have in principle impacted the poverty rate. Second, the results in Table 3b also point to an important role for informality and minimum wage in explaining poverty. Conditional on demographics and industry indicators, informality accounts for .7\% of the overall variance and $6 \%$ of the explained variance in poverty. Conditional on demographics, industry indicators, and informality, the "below the minimum wage" indicator accounts for $12.5 \%$ of the overall variance and 53\% of the explained variance in poverty (when the $\$ 3$ per day measure is used).

\footnotetext{
${ }^{15}$ Minimum wages in Colombia are set at the national level. The monthly minimum wage over our sample period (expressed in 1995 pesos) lies well above the poverty lines used by DANE; in particular, it is about 4 times the extreme poverty line (\$3 per day) and 1.7 times the regular poverty line (\$7 per day).
} 


\subsection{Summary}

Our descriptive analysis yields several findings that motivate our further work. First, poverty in urban Colombia is highly correlated with unemployment. A natural question is therefore whether the trade liberalization has had a significant impact on unemployment. However, poverty rates among the individuals living in households with employed head are also high, ranging from 14\% to $53 \%$ depending on the poverty line used. Within this group, poverty is highly correlated with employment of the household head in the informal sector and a wage below the minimum wage standard. The industry of employment also seems to matter. Given these patterns, it is natural to ask how the trade reforms affected the probability of a worker working in the informal sector, and whether trade liberalization affected compliance with minimum wage legislation. Furthermore, trade policy could also have affected poverty through its effects on worker wages. We take up these questions in the next section.

\section{Trade Policy and Poverty}

\subsection{The Evolution of the Aggregate Poverty Rate: The Aggregate Trends}

Before investigating the relationship between trade liberalization and poverty, it is useful to examine some aggregate trends in the evolution of poverty rates over our sample period. A clear pattern emerging from Table 1 is that no matter what poverty definition one adopts, poverty rates seem to steadily decline between 1984 and 1994/1995 and increase thereafter. By 1998 the poverty rates are close to the rates observed in 1984. The usual explanation offered in the literature for the 1996-1998 increase in urban poverty is the recession (see World Bank (2002)). The reasons for the steady decline of urban poverty between 1984 and 1995 are however less clear. Given that 1985-1994 was the period of trade reforms it is tempting to attribute the decrease of urban poverty to the changes initiated by the reforms.

To obtain a preliminary idea what factors lowered the poverty rate between 1984 and 1994 we start our analysis by asking whether the decline in the poverty rate was primarily driven be a decline in unemployment, or a decline in the poverty rate within the set of unemployed individuals. In particular, we decompose the decline in the poverty rate between 1986 and 
$1994^{16}, \Delta P_{t}$, into two components, the reduction in unemployment (the between component) and the reduction of poverty within the unemployed (the within component): $\Delta P_{t}=P_{t}-P_{\tau}=\sum_{j} \Delta U_{j t} p_{j .}+\sum_{j} \Delta p_{j t} U_{j}$., where j indicates the employment status of the household head (inactive, employed, or unemployed), $U_{j t}$ indicates the share of individuals living in households with status $\mathrm{j}$ in year $\mathrm{t}, p_{j \mathrm{t}}$ is the poverty rate within status $\mathrm{j}$ at time $\mathrm{t}$, $U_{j} .=.5\left(U_{j t}+U_{j \tau}\right)$, and $p_{j} .=.5\left(p_{j t}+p_{j \tau}\right) \cdot{ }^{17}$

The results are displayed in the top 2 panels of Table 4. The top panel includes all individuals, while the second one focuses only on those living in households with household head that is in the labor force (thus excluding inactive category). What is striking about the decomposition in Table 4 is that the "within” component accounts for over $90 \%$ of the decline in the poverty rate between 1994 and 1986. Hence, the decline in the poverty rate between 1986 and 1994 is explained mostly by an improvement in the position of household heads within each of our employment categories, rather than movements out of unemployment. This is a rather surprising result as we would have expected the decline in poverty to be associated with a decline in unemployment. The contribution of the "within" component is also significant for explaining the increase in the poverty rate between 1994 and 1998, though its magnitude is smaller than the one for the 1986-1994 period. Thus, the results for the second sub-period of our sample (1994-1998) are more consistent with the anecdotal claim that the increase in poverty during the late 1990's is due to the recession, as they suggest a larger role of the "between" component (movement into unemployment).

We next focus on poverty changes among the individuals living in households with employed household head. In particular, we have further decomposed the decline in the poverty rate among the individuals living in households with an employed household head into "within" and "between" components for each of the variables highly correlated with poverty: industry affiliation, employment in the informal sector, and a wage below the minimum wage. The results from these decompositions are displayed at the bottom of Table 4, and exhibit the same pattern as the ones regarding unemployment: the "within” component dominates the "between"

\footnotetext{
${ }^{16}$ In this decomposition, we focus on 1986 rather than 1984 because 1986 is the first year in our data with all available variables.

${ }^{17}$ This decomposition is similar to the one often used in the literature on skill-upgrading in order to decompose the increase in the share of skilled workers into a "within" industry and "between" industries component.
} 
component in every case. With respect to industry affiliation and informality in particular, the share of the "within" component exceeds 90\%, while for the minimum wage it is smaller, but still significant (60\%). Hence, the decline in poverty occurred predominately through improvements in the position of individuals at their current jobs, rather than changes in their employment. $^{18}$

What does the above analysis imply about the role of trade policy in reducing poverty? Given that the trade policy changes were concentrated in the early period, when the "between" movements are small, it seems unlikely that any effect that trade liberalization may have had on poverty was driven primarily by movements of people out of categories associated with high poverty (e.g., unemployment, informality) and into categories with lower poverty (employment, formal sector employment, minimum wage). It is however possible that trade policy affected poverty by impacting the wages of employees within the above defined categories. In addition, trade liberalization could be relevant for explaining the "between" component of poverty changes, small as this may be. We therefore turn now to a more systematic investigation of the relationship between trade liberalization and poverty.

\subsection{Trade Policy and Unemployment}

The high incidence of poverty among the unemployed leads to the question of how trade liberalization has affected unemployment. Unfortunately, this is not a question that can be answered convincingly with the available data. Ideally, one would like to identify the relationship between trade policy and unemployment by relating detailed industry tariff changes to changes in industry unemployment. However, the lack of detailed data on industry affiliation of the unemployed in the NHS precludes such an analysis. The unemployed workers who were previously employed report the last industry of employment at the 1-digit ISIC level. Similarly, the unemployed individuals who were not previously employed report the industry in which they are seeking employment at the 1-digit ISIC level. This leads to 9 industry observations per year, and only 6 out of 9 of these industries have available tariffs. Most importantly, most of the time-

\footnotetext{
${ }^{18}$ We have also replicated the analysis in Table 4 focusing only on individuals that are in the labor force and using their own employment characteristics for decomposition (rather than the characteristics of the household head). This addresses the concern that numbers in Table 4 might understate the between movements, if secondary bread winners are more likely to lose jobs during a recession. Although (as expected) the between component increases somewhat, the within component continues to play the dominant role.
} 
variation in tariffs occurred within the manufacturing industries, which are now treated as a single sector.

Nevertheless, given the importance of unemployment in explaining poverty in urban Colombia, we conduct two exercises to obtain a rough idea about the role of trade policy in affecting unemployment.

The first exercise is to examine whether the change in the probability of being unemployed over the time of trade reform was greater for workers employed in traded-good sectors (such as manufacturing) than for workers with the same observable characteristics in non-traded-good sectors (such as wholesale and retail trade, restaurants, hotels, construction, etc.). This exercise was conducted in one of our previous papers (Attanasio, Goldberg and Pavcnik (2004), section 8). In particular, we regressed an indicator for whether an individual was unemployed, on 1-digit ISIC industry indicators (wholesale and retail trade, restaurants/hotels (ISIC 6) was the omitted category), an indicator for a year following the trade reform, the interaction of industry indicators with the year indicator, and a set of worker characteristics (age, age squared, male, married, head of the household, education indicators, literate, lives in Bogota, born in urban area, time in residence, urban birth*time in residence). If the probability of being unemployed increased (decreased) relatively more over time in manufacturing relative to a sector such as wholesale and retail trade and restaurants and hotels (i.e., the coefficient on the interaction of the manufacturing indicator with year indicator were positive (negative) and significant), this could provide some indirect (and suggestive) evidence that trade reforms were associated with increases (decreases) in the probability of unemployment.

To summarize the results from that exercise, we found no evidence that the probability of unemployment changed significantly in the manufacturing sector relative to most non-traded sectors between 1984 and 1998, even though the manufacturing sector experienced drastic tariff declines. Given that the comparison of years 1984 and 1998 could have potentially missed shortterm adjustments to trade reform, we also considered the unemployment adjustment in periods right before and after the major tariff declines by focusing on changes in unemployment between 1988 and 1992. The coefficient on the interaction of the manufacturing indicator with the posttrade-reform year indicator indicated in this case a decrease in the probability of becoming unemployed in the manufacturing sector relative to the wholesale and retail trade sector. It is not clear however whether this decline was due to the trade reforms per se, or to the exchange rate 
depreciation in 1990/91 that lowered the demand for non-traded goods relative to traded goods. This decrease however seems short-lived. In the long-run (i.e. 1984-98), we do not find any evidence that the probability of unemployment changed in traded sectors relative to non-traded sectors.

The second exercise is to directly relate the probability of becoming unemployed to trade-related variables, such as tariffs, lagged imports and lagged exports. These variables refer to the (1-digit SIC) industry in which the currently unemployed person used to work (or industry in which a person is looking for work for the first time job seekers). In particular, we regress an indicator of whether an individual is unemployed on his/her demographic characteristics (listed in the note to the table), 1-digit industry dummies, year dummies, 1-digit SIC tariff rates, lagged imports and lagged exports. For industries for which DNP does not report tariffs we set the tariff rate equal to zero. ${ }^{19}$ When interpreting the results of this regression it is important to keep in mind that we only have variation in tariff rates in nine 1-digit ISIC industries, some of which actually never experience tariff changes. Hence, due to the high level of aggregation, we may not have sufficient variation in the data to identify the link between trade-related variables and unemployment, even though such a link might be evident at a finer level of aggregation.

The results are presented in Table 5 and show no association between tariff and unemployment. Furthermore, there is no evidence that there is a relationship between exports and unemployment. We do find, however, that as (lagged) imports increase, the probability of becoming unemployed increases. Overall, the evidence seems mixed and inconclusive. While, as emphasized above, the results are only suggestive given the high level of aggregation and the potential endogeneity of some of the variables we employ on the right hand side (such as imports or exports), it seems fair to say that whatever effects the trade reforms may have had on unemployment, they were not substantial enough to be evident in the raw data, at least not at the 1-digit SIC level of aggregation. Even at a more disaggregate level, the stability of industry employment shares we observe over this period does not seem to support the idea that trade liberalization had a significant impact on unemployment. Specifically, in Attanasio, Goldberg and Pavcnik (2004) we computed the employment shares by 2-digit SIC industry for periods before and periods after the trade reforms. The changes were found to be surprisingly small,

\footnotetext{
${ }^{19}$ This is likely not a bad assumption because all these industries are services.
} 
suggesting that despite the magnitude of tariff cuts and the extent of the overall reform, there was neither increased nor decreased unemployment at the industry level.

In sum, the above two exercises do not provide strong evidence that trade policy affected probability of becoming unemployed in either direction.

So far, our analysis has concentrated on the question of whether unemployed individuals are unemployed because of trade-related reasons. A somewhat different, yet for the poverty discussion relevant question is whether, within the set of unemployed individuals, those who became unemployed because of trade-related reasons fare worse, in the sense of being poorer than the rest. This could be for example the case if individuals who were laid off from industries facing intense import competition have a harder time finding a new job, so that they remain unemployed for a longer period of time; or, if increased import competition had affected their earnings in the past, when they were employed, leading to lower interest income when they became unemployed. Unfortunately, it is not possible to answer these questions definitively without panel data that would allow us to track individuals over time, trace their earnings, and compute unemployment hazard rates. But as before, we can obtain a rough idea about the empirical relevance of the above considerations by trying to link poverty within the unemployed directly to trade-related variables. In unreported regressions, we have regressed the likelihood of being poor among the unemployed on tariffs, lagged imports, lagged exports, industry indicators, and aforementioned individual demographic characteristics. The results were again mixed and not robust across different definitions of poverty.

Overall, while poverty in urban Colombian is clearly highly correlated with unemployment, we do not find any strong and conclusive evidence that the trade reform activity affected unemployment in either direction.

\subsection{Trade Policy and Informality}

Having found no evidence of a link between trade liberalization and changes in unemployment at the industry level, we next turn to the question of whether the trade reforms affected poverty within the set of employed individuals. Given that within the set of employed individuals poverty rates were particularly high for those working in the informal sector, we start by examining whether trade liberalization led to worker reallocation across the formal and informal sectors. 
In a previous paper (Goldberg and Pavcnik (2003)) we presented evidence that the tariff declines in Colombia were associated with an increase in the probability of being employed in the informal sector, though the effects were small, and applied only to the period preceding the labor market reform (but not thereafter). ${ }^{20}$ Moreover, we have found that informal work is associated with lower benefits and worse working conditions, and that informal workers face lower wages than workers with the same observable characteristics in the formal sector. Of course, these correlations do not necessarily imply that informal workers are worse off than formal workers given that there may be sorting into the informal sector based on unobservable characteristics -for example, workers may self-selected into informal sector because they value the flexible hours informal employment offers. Nonetheless, given that our descriptive results in section 4.2 suggest that a non-negligible share of informal workers are not just worse off than formal workers in terms of monetary compensation, but actually poor (especially when one considers the higher poverty lines), the concern arises that trade policy may have contributed to poverty by leading to a reallocation of labor towards the informal sectors. ${ }^{21}$

To examine this possibility more thoroughly we repeat the analysis of our earlier paper (that focused on pooled sample of employed individuals) both for the entire sample and for subgroups of employed who might a-priori face a higher likelihood of being pushed into the informal sector when the economy opens up to import competition. In particular, in table 6a we regress an indicator of whether an employed individual works in the informal sector on demographic characteristics (listed in the note to the table), industry indicators, year dummies, tariffs, and the interaction of tariffs with an indicator for whether the time period was covered by labor market reform. This approach is similar to the two-stage approach we have employed in our earlier work and the results are similar. Column 1 of the table corresponds to the specification we have used in our earlier work, except for the fact that our sample includes now unpaid family workers. It confirms our previous findings and suggests that higher tariff reductions are associated with a higher probability of being employed in the informal sector, but only in the period prior to the labor reform. In columns (2) to (7) we repeat the estimation separately for each of the following sub-groups: men, women, unskilled workers, skilled

\footnotetext{
${ }^{20}$ In 1990, Colombia instituted a labor market reform that significantly reduced the cost of hiring and firing workers (Kugler (1999) and Edwards (2001)).

${ }^{21}$ For a detailed analysis of the arguments why this may happen and a formal model linking trade liberalization with changes in the informal employment see Goldberg and Pavcnik (2003).
} 
workers, workers employed in large firms (11 or more people) and workers employed in small firms (i.e. less than 11 people). ${ }^{22}$ It is often alleged that women and unskilled workers are the most likely to switch to informal employment during trade reforms. The results in Table 6a seem to provide some support for this claim, as the increase in informality prior to the labor market reform is more likely to occur among women than men (compare columns (2) and (3)) and among unskilled than skilled workers (compare columns (4) and (5)), even though both of these estimates lie within each other's confidence intervals. Note also that the results in columns (6) and (7) indicate that the increases in informality associated with the tariff declines prior to the labor reform occur mostly in small establishments (employing less than 11 people). Columns (8) to (14) repeat the analysis that excludes the self-employed and yield similar findings.

Table $6 \mathrm{~b}$ extends the analysis by including, in addition to tariffs, lagged imports and exports as measures of trade exposure. The results regarding the effects of the tariff declines remain robust (although we now find evidence of increases in informality associated with the tariff declines in both large and small firms prior to the labor reform). What is interesting is that the results for exports suggest that higher exports are associated with lower probability of working in the informal sector. This result is mainly driven by large firms. The negative association between exports and informal employment is consistent with anecdotal evidence suggesting that large export firms are more likely to offer more permanent jobs, higher benefits, and better working conditions, possibly out of concern for public scrutiny.

Overall the results are in line with the evidence presented in our earlier work, suggesting that the Colombian tariff reductions were associated with a slight increase in informal employment, but only in the period preceding the labor market reform. Given that the poverty rate is higher in the informal sector, one would then have expected an increase in the aggregate poverty rate. ${ }^{23}$ This is clearly not the case; the aggregate poverty rate decreases during the 19861995 period. Moreover, the decomposition in Table 4 suggests not only that the role of "between" movements was limited, but also that to the extent that worker reallocation across the formal and informal sectors contributed to the poverty reduction, this happened by workers moving out of the informal and into the formal sector. This is precisely the opposite of the effect attributed to tariff reductions. Hence, it appears that the tariff-induced changes in informal

\footnotetext{
${ }^{22}$ Our definition of large is driven by the survey question (which does not distinguish among the size of establishments that employ more than 11 people).

${ }^{23}$ Of course this is only true to the extent that the wages paid to informal workers did not simultaneously increase.
} 
employment not only did not contribute to the poverty reduction witnessed during this period, but if anything, they went in the opposite direction. It is important to keep in mind however that the estimated effects are small and disappear once the labor market reform becomes effective. ${ }^{24}$

\subsection{Trade Policy and Compliance with Minimum Wage Legislation}

A different channel through which trade liberalization could have affected poverty is by increasing the non-compliance of firms with minimum wage legislation. ${ }^{25}$ Non-compliance is definitely an issue in Colombia; according to our calculations, the percent of earners receiving wages below the minimum wage standard ranges from $17 \%$ to $30 \%$ in individual years, with no clear time trend evident in the data. It is interesting to note however that non-compliance peaks in 1992, a year following the most drastic tariff reductions.

To examine whether non-compliance was affected by the trade reforms we employ the same approach as before and regress an indicator for whether an employed individual receives a wage above the minimum wage on demographic characteristics (see notes to table 7 for details), industry indicators, year dummies and various measures of trade exposure. Although our preferred trade exposure measure is tariffs, we also consider lagged imports and exports. We estimate this relationship on a sample of employees (excluding self-employed and unpaid family workers) and experiment with different sub-samples of these workers. To summarize the results, there is no evidence that tariff declines are associated with changes in the compliance with minimum wage standard in the sample as a whole (column 1 and 10) or in various sub-samples of workers. ${ }^{26}$ We also find no association between (lagged) exports and non-compliance in the sample as a whole (column 10). However, higher (lagged) imports are associated with greater non-compliance with minimum wage laws in the overall sample (column 10) and this relationship holds in most sub-samples of the data. Reassuringly, this relationship holds among

\footnotetext{
${ }^{24}$ Although tariffs are our preferred measure of exposure to trade, the results for exports suggest that because Colombian exports increased between 1986 and 1994, higher exports could have in principle contributed to 19941986 poverty reductions through reallocations of workers from informal to formal sector. However, as emphasized before, the reallocation (i.e. between) component of poverty declines accounts for a very small part of poverty reduction between 1986 and 1994.

${ }^{25}$ Maloney and Nunez (2003) provide details on minimum wage legislation in Colombia.

${ }^{26}$ Negative association between tariffs and non-compliance among men and in small firms in columns 4 and 9, respectively is not robust to inclusion of lagged imports and exports.
} 
the unskilled workers, but not among the skilled workers (for whom the minimum wage legislation is less likely binding).

What does this imply about the role of trade policy in reducing poverty? Given that the massive trade liberalization of the late 1980's and early 1990's led to an increase in imports, the results in Table 7 seem to suggest that, if anything, trade liberalization should have led to lower compliance with minimum wages, and hence to an increase in poverty. Hence, our results regarding the effects of trade liberalization on poverty via the minimum wage channel are similar to the ones we obtained regarding the informality channel: in both cases we find some evidence that trade liberalization affected the relevant variables (compliance with minimum wage laws in the first case, employment in the informal sector in the second case), but in both cases the direction of the effect suggests that trade liberalization should have led to an increase in poverty. Thus, it seems safe to conclude that the poverty reduction we observe between 1986 and 1994 cannot be attributed to trade-policy-induced changes in informality, or minimum wage compliance.

\subsection{Trade Policy and Poverty: A Direct Assessment}

Our empirical analysis so far has failed to find any strong link between the Colombian trade liberalization and variables that could be related to the poverty reduction between 1986 and 1994. This is consistent with the results in Table 4 showing that the poverty reduction occurred mostly through "within” group changes in poverty rates, rather than movement of people “between” groups, regardless of whether the groups are defined in terms of employment, informality, or compliance with minimum-wage laws. What remains as a residual explanation is the possibility that trade liberalization affected poverty by directly affecting worker wages.

In earlier work (Goldberg and Pavcnik (2004a) and Attanasio, Goldberg and Pavcnik (2004)) we have examined the impact of the Colombian trade liberalization on relative wages and found that the trade reforms have contributed to an increase in relative wage dispersion. This evidence was based on analyzing the response of industry wage premia to the tariff declines; specifically, our work showed that industry wage premia declined more in sectors that experienced the largest tariff cuts. Given that these sectors were sectors that had lower wage 
premia prior to the trade reforms and employed a higher share of unskilled ${ }^{27}$ workers (textiles and apparel, footwear, wood and wood products) the decline in the wage premia further widened the gap between the rich and poor. Furthermore, our work found some suggestive evidence that the well documented increase in the economy-wide skill premium over that period could be partly due to the trade reforms. In particular, we documented that the largest increases in the share of skilled workers in each sector, occurred in the sectors that had the largest tariff cuts. Hence there are indications that the skill-biased technological change may have been in part induced, or at a minimum reinforced, by the trade reforms.

Given these previous results on the effects of the trade reforms on relative wages, trade liberalization would have had to have a large positive effect on absolute wages in order to reduce poverty. As we pointed out in the Introduction, this effect would have been most likely realized through growth. However, the effect of trade policy changes on aggregate growth cannot be identified, as they cannot be separated from other policy changes and events that may have concurrently affected growth.

We therefore resort to the same partial-equilibrium identification strategy we used in the earlier exercises to examine whether the trade policy changes can be directly linked to changes in the poverty rates by sector of employment. This identification strategy relies on the fact that the tariff reductions in the Colombian trade reforms affected industries differentially. Given our earlier results, we would be surprised if we found any effects. Nevertheless, examining the link between trade liberalization and poverty reduction in a direct way serves as a check that we haven't missed any other important channels through which the trade reforms may have affected poverty at the industry level.

In Table 8, we regress an indicator for whether an employed individual is poor on individual characteristics, 2 digit ISIC industry dummies, year dummies, and trade exposure measures. ${ }^{28}$ While we do not find any robust evidence regarding the effects of tariff declines on poverty, higher imports are associated with higher poverty rates at the sectoral level, while higher exports are associated with lower poverty rates (albeit the letter results depend in part on the poverty line we use). Furthermore, we find that conditional on imports and exports, lower

\footnotetext{
${ }^{27}$ The terms "skilled” and "unskilled” were defined based on education. In particular, we define as "unskilled” workers who have at most primary education.

${ }^{28}$ For a discussion of the analysis of the same relationship for unemployed individuals, see end of section 5.2.
} 
tariffs are associated with a higher probability of being poor, when the lower poverty lines (\$1, \$2 and \$3 per day) are used.

This evidence on the direct relationship between trade liberalization and poverty among the employed at the sectoral level is consistent with our earlier findings concerning the effects on informality and minimum-wage compliance, and most likely partly driven by them. In all cases the empirical analysis suggests that trade liberalization either had no effects on poverty, or - to the extent that it had any - these effects went in the direction of increasing poverty.

\section{Conclusions}

Between 1985 and 1995 Colombia experienced massive trade liberalization. At the same time urban poverty declined by approximately 10\%. The chronological coincidence of trade liberalization and poverty reduction raises the question of whether the former has contributed to the latter. In this paper we have tried to establish a link between the trade reforms and the changes in urban poverty, approaching the task from many different angles.

To summarize our findings, we fail to find evidence of such a link. Our descriptive results establish that poverty in urban areas is highly correlated with unemployment, employment in the informal sector, and non-compliance with minimum wages. The poverty rates among the employed also differ by industry, suggesting a potential role of industry affiliation in explaining poverty. However, we find no evidence that the trade reforms impacted any of the above variables in a significant way. To the extent that we find any effects, the effects are small and go in the wrong direction, suggesting that the trade reforms may have contributed to an increase in urban poverty. Perhaps more surprisingly, we find that most of the reduction in urban poverty between 1986 and 1994 is accounted for by "within” group changes in poverty, rather than movements of people out of groups with high poverty rates, such as the "unemployed", "informal sector workers", and "below the minimum wage earners". Given these patterns, it is not surprising that we also fail to find any evidence of a direct link between the trade reforms and the poverty reductions by sector.

How does one then explain the poverty decline between 1986 and 1994? The residual explanation left to us is that there was an economy-wide increase in absolute wages, pronounced enough to compensate for the worsening of the relative position of individuals at the left tail of 
the income distribution. Whether this increase was brought about through the trade reforms is a question we cannot answer given that the trade policy changes coincide with other reforms (e.g. labor market reform), and other events that may have also affected wages. But it seems fair to conclude that to the extent trade liberalization had any role at all in the decline of poverty during that period, this was through the operation of general equilibrium effects, the potential effects of lower tariffs on the prices of consumer goods, and the potential impact of free trade on growth. 


\section{References}

Attanasio, O., Goldberg P., and N. Pavcnik (2004): “Trade Reforms and Wage Inequality in Colombia”, Journal of Development Economics 74, 331-366.

Chen, S. and M. Ravallion (2001): “How did the world's poorest fare in the 1990s?” Review of Income and Wealth 47, pp. 283-300.

Chen, S. and M. Ravallion (2004a): "How have the world's poorest fared since the early 1980s?" World Bank Policy Research Working Paper 3341.

Chen, S. and M. Ravallion (2004b): "Household Welfare Impacts of WTO Accession in China", World Bank Economic Review, forthcoming.

Deaton, A. and C. Paxson (1997): "Poverty among children and the elderly in developing countries”, Research Program in Development Studies Working Paper, Princeton University mimeo.

Edwards, S. (2001): The economics and politics of transition to an open market economy: Colombia. OECD: Paris and Washington, D.C..

Feenstra, R. and G. Hanson (1996): "Foreign Investment, outsourcing and relative wages”, in R.C. Feenstra et. al. (eds). Political economy of trade policy: essays in honor of Jagdish Bhagwati: MIT Press, Cambridge, 89-127

Feenstra, R. and G. Hanson (1997): "Foreign direct investment and relative wages: Evidence from Mexico's maquiladoras,” Journal of International Economics 42, 371-393.

Goldberg, P. and N. Pavcnik (2003): “The Response of the Informal Sector to Trade Liberalization”, Journal of Development Economics, 72, 463-496.

Goldberg, P. and N. Pavcnik (2004a): "Trade Protection and Wages: Evidence from the Colombian Trade Reforms", Journal of International Economics, forthcoming.

Goldberg, P. and N. Pavcnik (2004b): “Trade, Inequality and Poverty: What Do We Know?”, Brookings Trade Forum 2004 (also available as NBER Working Paper 10593, July 2004).

Hallak, J.C. and J. Levinsohn (2004): “Fooling Ourselves: Evaluating the Globalization and Growth Debate,” NBER Working Paper 10244.

Kugler, A. (1999): “The Impact of Firing Costs on Turnover and Unemployment: Evidence from The Colombian Labour Market Reform”, International Tax and Public Finance Journal, Vol. 6, no. 3, pp. 389-410. 
Maloney, W. and J. Nunez (2003): “Measuring the Impact of Minimum Wages: Evidence from Latin America,” NBER Working Paper 9800.

Ravallion, M. (2004): “Competing Concepts of Inequality in the Globalization Debate”, Brookings Trade Forum 2004.

Porto, G. (2004): “Using Survey Data to Assess the Distributional Effects of Trade Policy,” World Bank mimeo. Washington, DC: World Bank.

Winters, A., N. McCulloch, and A. McKay (2004): “Trade Liberalization and Poverty: The Evidence so Far,” Journal of Economic Literature 62, 72-115.

World Bank (not dated). Poverty Manual, available online at: http://www.worldbank.org/wbi/povertyanalysis/manual/\#ar

World Bank (2002). Colombia Poverty Report. World Bank. Available online at http://nnweb18.worldbank.org/external/lac/lac.nsf/Countries/Colombia/CC081B1813AF2789852 56BA300824DE6?OpenDocument 
Table 1: Poverty Headcount Ratios

\begin{tabular}{lrrrrrrrr}
\hline \hline & 1984 & 1986 & 1988 & 1990 & 1992 & 1994 & 1996 & 1998 \\
& & & & & & & & \\
$\$ 1$ & .025 & .025 & .018 & .014 & .018 & .011 & .022 & .028 \\
$\$ 2$ & .069 & .067 & .057 & .051 & .058 & .037 & .055 & .073 \\
$\$ 3$ & .158 & .157 & .139 & .129 & .130 & .100 & .127 & .159 \\
$\$ 4$ & .263 & .259 & .243 & .241 & .239 & .182 & .214 & .248 \\
$\$ 5$ & .366 & .377 & .336 & .344 & .341 & .278 & .311 & .346 \\
$\$ 7$ & .528 & .541 & .516 & .513 & .508 & .431 & .474 & .489 \\
DANE Poverty & & & .55 & & & $0.48^{*}$ & & $0.55^{* *}$ \\
DANE Extreme Poverty & & & .17 & & & $0.1^{*}$ & & $0.14^{* *}$ \\
\hline \hline
\end{tabular}

Note: As in Chen and Ravallion (2001), \$1 a day line in 1993 PPP is $\$ 1.08$ a day line (same applies to its multiples). All estimates are computed using survey weights. Column 1 refers to the poverty line used in the computation of poverty rates in each row. The DANE Poverty Rate and Extreme Poverty Rate are from World Bank (2002), table 2 based on DANE poverty lines. These rates are available only for selected years $(1988,1995$, 1998). *Number is for 1995 . **Number is for 1999. 
Table 2a--Poverty Headcount Ratios by Household Head Characteristics

\begin{tabular}{|c|c|c|c|c|c|c|c|c|}
\hline & $\$ 1$ & $\$ 2$ & $\$ 3$ & $\$ 4$ & $\$ 5$ & $\$ 7$ & $\begin{array}{r}\text { ottom } \\
10 \% \\
\end{array}$ & $\begin{array}{r}\text { ottom } \\
20 \% \\
\end{array}$ \\
\hline Inactive & .028 & .078 & .151 & .246 & .360 & .516 & .115 & .196 \\
\hline Unemployed & .188 & .310 & .477 & .594 & .704 & .814 & .388 & .527 \\
\hline Employed & .016 & .052 & .141 & .245 & .363 & .531 & .091 & .184 \\
\hline No school & .042 & .118 & .261 & .405 & .553 & .726 & .185 & .323 \\
\hline Elementary & .022 & .061 & .149 & .263 & .393 & .577 & .100 & .197 \\
\hline Secondary & .011 & .018 & .053 & .087 & .150 & .296 & .030 & .065 \\
\hline University & .006 & .006 & .008 & .014 & .037 & .077 & .007 & .011 \\
\hline Age $<=20$ & .043 & .115 & .154 & .261 & .339 & .572 & .145 & .176 \\
\hline $21-30$ & .026 & .064 & .145 & .264 & .400 & .567 & .098 & .193 \\
\hline $31-40$ & .030 & .083 & .190 & .296 & .421 & .581 & .131 & .236 \\
\hline $41-50$ & .023 & .063 & .159 & .264 & .373 & .548 & .104 & .203 \\
\hline $51-60$ & .020 & .051 & .130 & .213 & .328 & .486 & .083 & .163 \\
\hline$>60$ & .030 & .084 & .169 & .232 & .331 & .481 & .106 & .179 \\
\hline Female & .030 & .084 & .169 & .267 & .379 & .523 & .125 & .208 \\
\hline Male & .024 & .063 & .154 & .258 & .376 & .545 & .103 & .198 \\
\hline
\end{tabular}

Notes: Households are grouped by the characteristics of the head of the household. The top row refers to the poverty line used in the calculations of the headcount ratio in each column. Bottom $10 \%(20 \%)$ refers to the individuals living in the bottom 10\% (20\%) of the income distribution in 1986. All figures are based on 1986 data, the first year of data with all relevant variables. All estimates are computed using survey weights. 
Table 2b: Poverty and Household Head Characteristics (regression results)

\begin{tabular}{|c|c|c|c|c|c|c|c|c|}
\hline & $\$ 1$ & $\$ 2$ & $\$ 3$ & $\$ 4$ & $\$ 5$ & $\$ 7$ & $\begin{array}{l}\text { bottom } \\
10 \% \\
\end{array}$ & $\begin{array}{l}\text { bottom } \\
20 \% \\
\end{array}$ \\
\hline Age & $\begin{array}{l}-0.0005 \\
{[0.367]}\end{array}$ & $\begin{array}{l}-0.0018^{* *} \\
{[0.030]}\end{array}$ & $\begin{array}{l}-0.0032 * * * \\
{[0.004]}\end{array}$ & $\begin{array}{l}-0.0061^{* * *} \\
{[0.000]}\end{array}$ & $\begin{array}{l}-0.0101^{* * *} \\
{[0.000]}\end{array}$ & $\begin{array}{l}-0.0120^{* * *} \\
{[0.000]}\end{array}$ & $\begin{array}{l}-0.0028^{* * *} \\
{[0.005]}\end{array}$ & $\begin{array}{l}-0.0043^{* * *} \\
{[0.001]}\end{array}$ \\
\hline Age squared & $\begin{array}{l}0 \\
{[0.423]}\end{array}$ & $\begin{array}{l}0 \\
{[0.228]}\end{array}$ & $\begin{array}{l}0 \\
{[0.231]}\end{array}$ & $\begin{array}{l}0.0000^{* *} \\
{[0.037]}\end{array}$ & $\begin{array}{l}0.0001^{* * *} \\
{[0.000]}\end{array}$ & $\begin{array}{l}0.0001^{* * *} \\
{[0.000]}\end{array}$ & $\begin{array}{l}0 \\
{[0.114]}\end{array}$ & $\begin{array}{l}0 \\
{[0.161]}\end{array}$ \\
\hline Male & $\begin{array}{l}0.0016 \\
{[0.679]}\end{array}$ & $\begin{array}{l}-0.0041 \\
{[0.499]}\end{array}$ & $\begin{array}{l}-0.0018 \\
{[0.833]}\end{array}$ & $\begin{array}{l}0.012 \\
{[0.216]}\end{array}$ & $\begin{array}{l}0.0268 * * \\
{[0.011]}\end{array}$ & $\begin{array}{l}0.0331^{* * *} \\
{[0.002]}\end{array}$ & $\begin{array}{l}-0.0062 \\
{[0.396]}\end{array}$ & $\begin{array}{l}0.0123 \\
{[0.176]}\end{array}$ \\
\hline Married & $\begin{array}{l}-0.0092^{* * *} \\
{[0.004]}\end{array}$ & $\begin{array}{l}-0.0288^{* * *} \\
{[0.000]}\end{array}$ & $\begin{array}{l}-0.0443^{* * *} \\
{[0.000]}\end{array}$ & $\begin{array}{l}-0.0616^{* * *} \\
{[0.000]}\end{array}$ & $\begin{array}{l}-0.0654^{* * *} \\
{[0.000]}\end{array}$ & $\begin{array}{l}-0.0391 * * * \\
{[0.000]}\end{array}$ & $\begin{array}{l}-0.0367 * * * \\
{[0.000]}\end{array}$ & $\begin{array}{l}-0.0603^{* * *} \\
{[0.000]}\end{array}$ \\
\hline Elementary & $\begin{array}{l}-0.0237^{* * *} \\
{[0.000]}\end{array}$ & $\begin{array}{l}-0.0671^{* * *} \\
{[0.000]}\end{array}$ & $\begin{array}{l}-0.1152^{* * *} \\
{[0.000]}\end{array}$ & $\begin{array}{l}-0.1446^{* * *} \\
{[0.000]}\end{array}$ & $\begin{array}{l}-0.1704^{* * * *} \\
{[0.000]}\end{array}$ & $\begin{array}{l}-0.1593^{* * *} \\
{[0.000]}\end{array}$ & $\begin{array}{l}-0.0946^{* * *} \\
{[0.000]}\end{array}$ & $\begin{array}{l}-0.1330^{* * *} \\
{[0.000]}\end{array}$ \\
\hline Secondary & $\begin{array}{l}-0.0333^{* * *} \\
{[0.000]}\end{array}$ & $\begin{array}{l}-0.1031^{* * *} \\
{[0.000]}\end{array}$ & $\begin{array}{l}-0.1988 * * * \\
{[0.000]}\end{array}$ & $\begin{array}{l}-0.2981^{* * * *} \\
{[0.000]}\end{array}$ & $\begin{array}{l}-0.3959 * * * \\
{[0.000]}\end{array}$ & $\begin{array}{l}-0.4364^{* * * *} \\
{[0.000]}\end{array}$ & $\begin{array}{l}-0.1538^{* * * *} \\
{[0.000]}\end{array}$ & $\begin{array}{l}-0.2476^{* * * *} \\
{[0.000]}\end{array}$ \\
\hline University & $\begin{array}{l}-0.0359 * * * \\
{[0.000]}\end{array}$ & $\begin{array}{l}-0.1054^{* * *} \\
{[0.000]}\end{array}$ & $\begin{array}{l}-0.2247^{* * *} \\
{[0.000]}\end{array}$ & $\begin{array}{l}-0.3445^{* * *} \\
{[0.000]}\end{array}$ & $\begin{array}{l}-0.4808^{* * *} \\
{[0.000]}\end{array}$ & $\begin{array}{l}-0.6219 * * * \\
{[0.000]}\end{array}$ & $\begin{array}{l}-0.1640 * * * \\
{[0.000]}\end{array}$ & $\begin{array}{l}-0.2815^{* * *} \\
{[0.000]}\end{array}$ \\
\hline HH size & $\begin{array}{l}-0.0004 \\
{[0.495]}\end{array}$ & $\begin{array}{l}0.0077^{* * *} \\
{[0.000]}\end{array}$ & $\begin{array}{l}0.0240 * * * \\
{[0.000]}\end{array}$ & $\begin{array}{l}0.0398^{* * *} \\
{[0.000]}\end{array}$ & $\begin{array}{l}0.0462^{* * *} \\
{[0.000]}\end{array}$ & $\begin{array}{l}0.0511^{* * *} \\
{[0.000]}\end{array}$ & $\begin{array}{l}0.0145^{* * *} \\
{[0.000]}\end{array}$ & $\begin{array}{l}0.0299 * * * \\
{[0.000]}\end{array}$ \\
\hline Unemployed & $\begin{array}{l}0.1559 * * * \\
{[0.000]}\end{array}$ & $\begin{array}{l}0.2441^{* * *} \\
{[0.000]}\end{array}$ & $\begin{array}{l}0.3026^{* * * *} \\
{[0.000]}\end{array}$ & $\begin{array}{l}0.2990^{* * * *} \\
{[0.000]}\end{array}$ & $\begin{array}{l}0.2861^{* * *} \\
{[0.000]}\end{array}$ & $\begin{array}{l}0.2121^{* * *} \\
{[0.000]}\end{array}$ & $\begin{array}{l}0.2778^{* * * *} \\
{[0.000]}\end{array}$ & $\begin{array}{l}0.2960 * * * \\
{[0.000]}\end{array}$ \\
\hline Employed & $\begin{array}{l}-0.0124^{* * *} \\
{[0.004]}\end{array}$ & $\begin{array}{l}-0.0168^{* * *} \\
{[0.010]}\end{array}$ & $\begin{array}{l}-0.0147 * \\
{[0.098]}\end{array}$ & $\begin{array}{l}-0.0163 \\
{[0.118]}\end{array}$ & $\begin{array}{l}-0.0195^{*} \\
{[0.084]}\end{array}$ & $\begin{array}{l}-0.0307^{* * *} \\
{[0.007]}\end{array}$ & $\begin{array}{l}-0.0191^{* *} \\
{[0.014]}\end{array}$ & $\begin{array}{l}-0.0242^{* *} \\
{[0.013]}\end{array}$ \\
\hline $\mathrm{R}_{1}{ }^{2}$ & .009 & .035 & .075 & .122 & .160 & .199 & .054 & .095 \\
\hline $\begin{array}{l}\mathrm{R}^{2} \\
\text { Observations }\end{array}$ & $\begin{array}{l}.050 \\
16,933\end{array}$ & $\begin{array}{l}.076 \\
16,933\end{array}$ & $\begin{array}{l}.106 \\
16,933\end{array}$ & $\begin{array}{l}.144 \\
16,933\end{array}$ & $\begin{array}{l}.176 \\
16,933\end{array}$ & $\begin{array}{l}.209 \\
16,933\end{array}$ & $\begin{array}{l}.090 \\
16,933\end{array}$ & $\begin{array}{l}.121 \\
16,933\end{array}$ \\
\hline
\end{tabular}

Note: P values are reported in parenthesis. ${ }^{* * *}$, ** and * indicate 1,5 , and $10 \%$ significance, respectively. The top row indicates the poverty line used to create the poverty indicator in a given column. $\mathrm{R}_{1}{ }^{2}$ refers to $\mathrm{R}^{2}$ from a regression that does not include employment and unemployment indicators. Bottom 10\% (20\%) refers to the individuals living in the bottom $10 \%$ (20\%) of the income distribution in 1986. All figures are based on 1986 data, the first year of data with all relevant variables. Number of observations refers to number of households in 1986 data. 
Table 3a: Headcount Ratios by Household Head Characteristics for Households with Employed Household Head

\begin{tabular}{|c|c|c|c|c|c|c|c|c|}
\hline & $\$ 1$ & $\$ 2$ & $\$ 3$ & $\$ 4$ & $\$ 5$ & $\$ 7$ & $\begin{array}{c}\text { oottom } \\
10 \% \\
\end{array}$ & $\begin{array}{r}\text { bottom } \\
20 \% \\
\end{array}$ \\
\hline Agriculture and Hunting & .020 & .046 & .167 & .292 & .377 & .509 & .100 & .215 \\
\hline Forestry and logging & .000 & .000 & .063 & .337 & .337 & .337 & .000 & .337 \\
\hline Fishing & .000 & .094 & .172 & .172 & .172 & .480 & .094 & .172 \\
\hline Coal Mining & .000 & .000 & .071 & .071 & .233 & .527 & .071 & .071 \\
\hline Petroleum and Natural Gas & .000 & .000 & .014 & .034 & .090 & .205 & .000 & .034 \\
\hline Metal Ore Mining & .000 & .000 & .000 & .000 & .000 & .229 & .000 & .000 \\
\hline Other Mining & .119 & .143 & .306 & .634 & .778 & .778 & .195 & .336 \\
\hline Food & .008 & .038 & .117 & .237 & .361 & .538 & .081 & .168 \\
\hline Textile, Apparel, Leather & .011 & .031 & .120 & .216 & .344 & .553 & .063 & .152 \\
\hline Wood & .006 & .044 & .129 & .242 & .460 & .607 & .086 & .170 \\
\hline Paper & .015 & .015 & .048 & .120 & .215 & .375 & .023 & .059 \\
\hline Chemical & .008 & .026 & .093 & .167 & .276 & .440 & .058 & .127 \\
\hline Non-Metallic Mineral Products & .022 & .076 & .162 & .241 & .458 & .680 & .099 & .173 \\
\hline Basic Metal Industry & .000 & .021 & .146 & .215 & .419 & .576 & .021 & .204 \\
\hline Machinery and Equipment & .014 & .030 & .115 & .235 & .327 & .533 & .061 & .165 \\
\hline Other Manufacturing & .006 & .033 & .107 & .154 & .263 & .426 & .064 & .107 \\
\hline Electricity, Gas, Steam & .000 & .052 & .123 & .194 & .303 & .449 & .059 & .167 \\
\hline Water Works and Supply & .000 & .063 & .099 & .219 & .368 & .600 & .085 & .146 \\
\hline Construction & .013 & .058 & .191 & .326 & .488 & .675 & .109 & .246 \\
\hline Wholesale Trade & .004 & .004 & .054 & .118 & .137 & .324 & .009 & .063 \\
\hline Retail Trade & .030 & .099 & .190 & .299 & .409 & .560 & .145 & .244 \\
\hline Restaurants and Hotels & .026 & .063 & .177 & .291 & .414 & .612 & .123 & .227 \\
\hline Transport and Storage & .015 & .039 & .122 & .233 & .351 & .531 & .082 & .167 \\
\hline Communication & .000 & .000 & .053 & .073 & .163 & .313 & .000 & .073 \\
\hline Financial Institutions & .000 & .000 & .007 & .016 & .075 & .214 & .002 & .009 \\
\hline Insurance & .000 & .000 & .000 & .000 & .091 & .177 & .000 & .000 \\
\hline Real estate \& Business & .003 & .011 & .081 & .192 & .302 & .441 & .034 & .105 \\
\hline Public Administration & .000 & .007 & .044 & .136 & .232 & .449 & .015 & .068 \\
\hline Sanity & .000 & .000 & .100 & .300 & .581 & .759 & .050 & .235 \\
\hline Social and Community Services & .001 & .008 & .048 & .105 & .183 & .285 & .025 & .068 \\
\hline Recreation and Culture & .013 & .053 & .131 & .209 & .357 & .490 & .089 & .187 \\
\hline Household and Personal Services & .029 & .093 & .243 & .366 & .492 & .664 & .158 & .298 \\
\hline International Bodies & .000 & .000 & .000 & .000 & .525 & .525 & .000 & .000 \\
\hline Agriculture & .019 & .046 & .164 & .291 & .373 & .505 & .098 & .217 \\
\hline Mining & .041 & .049 & .125 & .247 & .350 & .465 & .081 & .144 \\
\hline Manufacturing & .011 & .034 & .115 & .215 & .347 & .535 & .067 & .152 \\
\hline Utilities & .000 & .056 & .114 & .202 & .325 & .500 & .068 & .160 \\
\hline Construction & .013 & .058 & .191 & .326 & .488 & .675 & .109 & .246 \\
\hline Wholesale and Retail Trade & .029 & .090 & .184 & .292 & .401 & .561 & .138 & .236 \\
\hline Transport & .014 & .037 & .118 & .224 & .340 & .519 & .077 & .161 \\
\hline Financing, Insurance, Business & .002 & .007 & .053 & .126 & .219 & .355 & .022 & .069 \\
\hline Community, Social, Personal Services & .013 & .046 & .135 & .230 & .340 & .497 & .083 & .174 \\
\hline Formal & .001 & .013 & .081 & .172 & .286 & .456 & .036 & .111 \\
\hline Informal & .026 & .080 & .186 & .298 & .419 & .586 & .131 & .237 \\
\hline Paid above minimum wage & .000 & .008 & .068 & .154 & .273 & .450 & .030 & .097 \\
\hline Paid below minimum wage & .074 & .215 & .410 & .577 & .697 & .832 & .315 & .502 \\
\hline Unpaid family worker & .187 & .271 & .385 & .670 & .707 & .966 & .385 & .445 \\
\hline Private Sector Employe & .005 & .027 & .125 & .240 & .374 & .557 & .064 & .167 \\
\hline Government Employee & .001 & .006 & .044 & .120 & .216 & .389 & .019 & .073 \\
\hline Domestic Employee & .022 & .083 & .310 & .424 & .528 & .736 & .168 & .345 \\
\hline Self-employed & .041 & .115 & .224 & .340 & .453 & .608 & .174 & .279 \\
\hline
\end{tabular}

Notes: See notes to table $2 \mathrm{a}$. 
Table 3b: Poverty and Household Head Characteristics for Households with Employed Head (\$3 and \$4 per day poverty line)

\begin{tabular}{|c|c|c|c|c|c|c|c|c|c|c|}
\hline & \multicolumn{5}{|c|}{ \$\$3 a day poverty line } & \multicolumn{5}{|c|}{ \$4 a day poverty line } \\
\hline & (1) & (2) & (3) & (4) & (5) & (1) & (2) & (3) & (4) & (5) \\
\hline Agriculture and Hunting & $\begin{array}{l}0.0012 \\
{[0.952]}\end{array}$ & $\begin{array}{l}0.0023 \\
{[0.908]}\end{array}$ & $\begin{array}{l}0.0234 \\
{[0.215]}\end{array}$ & $\begin{array}{l}0.0390^{*} \\
{[0.054]}\end{array}$ & $\begin{array}{l}0.0344 * \\
{[0.091]}\end{array}$ & $\begin{array}{l}0.0007 \\
{[0.978]}\end{array}$ & $\begin{array}{l}-0.004 \\
{[0.870]}\end{array}$ & $\begin{array}{l}0.0209 \\
{[0.354]}\end{array}$ & $\begin{array}{l}0.0397 \\
{[0.101]}\end{array}$ & $\begin{array}{l}0.0301 \\
{[0.218]}\end{array}$ \\
\hline Forestry and logging & $\begin{array}{l}-0.0704 \\
{[0.600]}\end{array}$ & $\begin{array}{l}-0.0502 \\
{[0.707]}\end{array}$ & $\begin{array}{l}-0.0049 \\
{[0.968]}\end{array}$ & $\begin{array}{l}-0.0075 \\
{[0.955]}\end{array}$ & $\begin{array}{l}-0.0058 \\
{[0.965]}\end{array}$ & $\begin{array}{l}0.1372 \\
{[0.391]}\end{array}$ & $\begin{array}{l}0.1561 \\
{[0.329]}\end{array}$ & $\begin{array}{l}0.2099 \\
{[0.156]}\end{array}$ & $\begin{array}{l}0.2022 \\
{[0.204]}\end{array}$ & $\begin{array}{l}0.2032 \\
{[0.202]}\end{array}$ \\
\hline Fishing & $\begin{array}{l}0.1522 \\
{[0.300]}\end{array}$ & $\begin{array}{l}0.1392 \\
{[0.342]}\end{array}$ & $\begin{array}{l}0.1444 \\
{[0.287]}\end{array}$ & $\begin{array}{l}0.129 \\
{[0.376]}\end{array}$ & $\begin{array}{l}0.1248 \\
{[0.391]}\end{array}$ & $\begin{array}{l}0.0307 \\
{[0.861]}\end{array}$ & $\begin{array}{l}0.0181 \\
{[0.917]}\end{array}$ & $\begin{array}{l}0.024 \\
{[0.882]}\end{array}$ & $\begin{array}{l}0.0067 \\
{[0.969]}\end{array}$ & $\begin{array}{l}0.0029 \\
{[0.987]}\end{array}$ \\
\hline Coal Mining & $\begin{array}{l}-0.1230^{*} \\
{[0.095]}\end{array}$ & $\begin{array}{l}-0.0938 \\
{[0.202]}\end{array}$ & $\begin{array}{l}-0.0584 \\
{[0.391]}\end{array}$ & $\begin{array}{l}-0.0702 \\
{[0.337]}\end{array}$ & $\begin{array}{l}-0.0623 \\
{[0.394]}\end{array}$ & $\begin{array}{l}-0.2227^{* *} \\
{[0.011]}\end{array}$ & $\begin{array}{l}-0.1951^{* *} \\
{[0.026]}\end{array}$ & $\begin{array}{l}-0.1532 * \\
{[0.060]}\end{array}$ & $\begin{array}{l}-0.1681^{*} \\
{[0.055]}\end{array}$ & $\begin{array}{l}-0.1617^{*} \\
{[0.065]}\end{array}$ \\
\hline Petroleum and Natural Gas & $\begin{array}{l}-0.1076^{*} \\
{[0.062]}\end{array}$ & $\begin{array}{l}-0.0921 \\
{[0.109]}\end{array}$ & $\begin{array}{l}-0.0352 \\
{[0.508]}\end{array}$ & $\begin{array}{l}-0.0561 \\
{[0.327]}\end{array}$ & $\begin{array}{l}-0.055 \\
{[0.336]}\end{array}$ & $\begin{array}{l}-0.1529^{* *} \\
{[0.026]}\end{array}$ & $\begin{array}{l}-0.1385^{* *} \\
{[0.044]}\end{array}$ & $\begin{array}{l}-0.0707 \\
{[0.266]}\end{array}$ & $\begin{array}{l}-0.0997 \\
{[0.145]}\end{array}$ & $\begin{array}{l}-0.0991 \\
{[0.147]}\end{array}$ \\
\hline Metal Ore Mining & $\begin{array}{l}-0.2165 \\
{[0.351]}\end{array}$ & $\begin{array}{l}-0.2283 \\
{[0.324]}\end{array}$ & $\begin{array}{l}-0.1114 \\
{[0.603]}\end{array}$ & $\begin{array}{l}-0.1449 \\
{[0.529]}\end{array}$ & $\begin{array}{l}-0.1604 \\
{[0.486]}\end{array}$ & $\begin{array}{l}-0.3501 \\
{[0.207]}\end{array}$ & $\begin{array}{l}-0.3618 \\
{[0.191]}\end{array}$ & $\begin{array}{l}-0.2219 \\
{[0.387]}\end{array}$ & $\begin{array}{l}-0.2761 \\
{[0.316]}\end{array}$ & $\begin{array}{l}-0.2898 \\
{[0.293]}\end{array}$ \\
\hline Other Mining & $\begin{array}{l}0.1351^{*} \\
{[0.074]}\end{array}$ & $\begin{array}{l}0.1186 \\
{[0.125]}\end{array}$ & $\begin{array}{l}0.0764 \\
{[0.286]}\end{array}$ & $\begin{array}{l}0.1715^{* *} \\
{[0.022]}\end{array}$ & $\begin{array}{l}0.1413^{*} \\
{[0.066]}\end{array}$ & $\begin{array}{l}0.3191^{* * *} \\
{[0.000]}\end{array}$ & $\begin{array}{l}0.3203^{* * *} \\
{[0.001]}\end{array}$ & $\begin{array}{l}0.2696^{* * *} \\
{[0.002]}\end{array}$ & $\begin{array}{l}0.3566 * * * \\
{[0.000]}\end{array}$ & $\begin{array}{l}0.3444^{* * *} \\
{[0.000]}\end{array}$ \\
\hline Food & $\begin{array}{l}-0.0802^{* * *} \\
{[0.000]}\end{array}$ & $\begin{array}{l}-0.0562 * * * \\
{[0.000]}\end{array}$ & $\begin{array}{l}-0.0258 * \\
{[0.079]}\end{array}$ & $\begin{array}{l}-0.0323 * * \\
{[0.041]}\end{array}$ & $\begin{array}{l}-0.0263^{*} \\
{[0.099]}\end{array}$ & $\begin{array}{l}-0.0741^{* * *} \\
{[0.000]}\end{array}$ & $\begin{array}{l}-0.0526 * * * \\
{[0.005]}\end{array}$ & $\begin{array}{l}-0.0166 \\
{[0.345]}\end{array}$ & $\begin{array}{l}-0.0246 \\
{[0.194]}\end{array}$ & $\begin{array}{l}-0.0209 \\
{[0.274]}\end{array}$ \\
\hline Textile, Apparel, Leather & $\begin{array}{l}-0.0704^{* * *} \\
{[0.000]}\end{array}$ & $\begin{array}{l}-0.0577^{* * * *} \\
{[0.000]}\end{array}$ & $\begin{array}{l}-0.0388^{* * *} \\
{[0.001]}\end{array}$ & $\begin{array}{l}-0.0367 * * * \\
{[0.003]}\end{array}$ & $\begin{array}{l}-0.0351^{* * *} \\
{[0.005]}\end{array}$ & $\begin{array}{l}-0.0813^{* * *} \\
{[0.000]}\end{array}$ & $\begin{array}{l}-0.0688^{* * *} \\
{[0.000]}\end{array}$ & $\begin{array}{l}-0.0465^{* * *} \\
{[0.001]}\end{array}$ & $\begin{array}{l}-0.0464 * * * \\
{[0.002]}\end{array}$ & $\begin{array}{l}-0.0448^{* * *} \\
{[0.003]}\end{array}$ \\
\hline Wood & $\begin{array}{l}-0.0629 * * * \\
{[0.002]}\end{array}$ & $\begin{array}{l}-0.0640^{* * * *} \\
{[0.002]}\end{array}$ & $\begin{array}{l}-0.0410^{* *} \\
{[0.030]}\end{array}$ & $\begin{array}{l}-0.0339 * \\
{[0.094]}\end{array}$ & $\begin{array}{l}-0.0390 * \\
{[0.055]}\end{array}$ & $\begin{array}{l}-0.0716^{* * *} \\
{[0.003]}\end{array}$ & $\begin{array}{l}-0.0711^{* * *} \\
{[0.003]}\end{array}$ & $\begin{array}{l}-0.0438 * \\
{[0.052]}\end{array}$ & $\begin{array}{l}-0.0416 * \\
{[0.085]}\end{array}$ & $\begin{array}{l}-0.0446 * \\
{[0.067]}\end{array}$ \\
\hline Paper & $\begin{array}{l}-0.0994 * * * \\
{[0.000]}\end{array}$ & $\begin{array}{l}-0.0738^{* * * *} \\
{[0.007]}\end{array}$ & $\begin{array}{l}-0.0439 * \\
{[0.086]}\end{array}$ & $\begin{array}{l}-0.0548 * * \\
{[0.046]}\end{array}$ & $\begin{array}{l}-0.0476^{*} \\
{[0.083]}\end{array}$ & $\begin{array}{l}-0.1159^{* * *} \\
{[0.000]}\end{array}$ & $\begin{array}{l}-0.0919 * * * \\
{[0.005]}\end{array}$ & $\begin{array}{l}-0.0565 * \\
{[0.065]}\end{array}$ & $\begin{array}{l}-0.0699 * * \\
{[0.033]}\end{array}$ & $\begin{array}{l}-0.0641 * \\
{[0.051]}\end{array}$ \\
\hline Chemical & $\begin{array}{l}-0.0610^{* * *} \\
{[0.005]}\end{array}$ & $\begin{array}{l}-0.0227 \\
{[0.307]}\end{array}$ & $\begin{array}{l}0.0039 \\
{[0.849]}\end{array}$ & $\begin{array}{l}-0.0108 \\
{[0.621]}\end{array}$ & $\begin{array}{l}0.0029 \\
{[0.898]}\end{array}$ & $\begin{array}{l}-0.0589^{* *} \\
{[0.024]}\end{array}$ & $\begin{array}{l}-0.0214 \\
{[0.422]}\end{array}$ & $\begin{array}{l}0.0064 \\
{[0.795]}\end{array}$ & $\begin{array}{l}-0.0072 \\
{[0.785]}\end{array}$ & $\begin{array}{l}0.0057 \\
{[0.831]}\end{array}$ \\
\hline Non-Metallic Mineral Products & $\begin{array}{l}-0.0322 \\
{[0.226]}\end{array}$ & $\begin{array}{l}-0.0002 \\
{[0.995]}\end{array}$ & $\begin{array}{l}0.0085 \\
{[0.733]}\end{array}$ & $\begin{array}{l}0.0191 \\
{[0.473]}\end{array}$ & $\begin{array}{l}0.0294 \\
{[0.271]}\end{array}$ & $\begin{array}{l}-0.0456 \\
{[0.152]}\end{array}$ & $\begin{array}{l}-0.0142 \\
{[0.658]}\end{array}$ & $\begin{array}{l}-0.0042 \\
{[0.888]}\end{array}$ & $\begin{array}{l}0.0075 \\
{[0.814]}\end{array}$ & $\begin{array}{l}0.0172 \\
{[0.590]}\end{array}$ \\
\hline Basic Metal Industry & $\begin{array}{l}-0.0502 \\
{[0.314]}\end{array}$ & $\begin{array}{l}-0.0243 \\
{[0.626]}\end{array}$ & $\begin{array}{l}0.0066 \\
{[0.887]}\end{array}$ & $\begin{array}{l}-0.0044 \\
{[0.930]}\end{array}$ & $\begin{array}{l}0.0027 \\
{[0.956]}\end{array}$ & $\begin{array}{l}-0.0767 \\
{[0.198]}\end{array}$ & $\begin{array}{l}-0.0522 \\
{[0.380]}\end{array}$ & $\begin{array}{l}-0.0155 \\
{[0.778]}\end{array}$ & $\begin{array}{l}-0.0293 \\
{[0.621]}\end{array}$ & $\begin{array}{l}-0.0235 \\
{[0.692]}\end{array}$ \\
\hline Machinery and Equipment & $\begin{array}{l}-0.0772^{* * *} \\
{[0.000]}\end{array}$ & $\begin{array}{l}-0.0541^{* * * *} \\
{[0.002]}\end{array}$ & $\begin{array}{l}-0.0179 \\
{[0.268]}\end{array}$ & $\begin{array}{l}-0.0302 * \\
{[0.082]}\end{array}$ & $\begin{array}{l}-0.0255 \\
{[0.146]}\end{array}$ & $\begin{array}{l}-0.0688^{* * *} \\
{[0.001]}\end{array}$ & $\begin{array}{l}-0.0459^{* *} \\
{[0.028]}\end{array}$ & $\begin{array}{l}-0.0029 \\
{[0.879]}\end{array}$ & $\begin{array}{l}-0.0202 \\
{[0.330]}\end{array}$ & $\begin{array}{l}-0.0155 \\
{[0.459]}\end{array}$ \\
\hline Other Manufacturing & $\begin{array}{l}-0.0551 \\
{[0.160]}\end{array}$ & $\begin{array}{l}-0.0525 \\
{[0.179]}\end{array}$ & $\begin{array}{l}-0.0409 \\
{[0.258]}\end{array}$ & $\begin{array}{l}-0.0483 \\
{[0.214]}\end{array}$ & $\begin{array}{l}-0.0481 \\
{[0.216]}\end{array}$ & $\begin{array}{l}-0.1052^{* *} \\
{[0.025]}\end{array}$ & $\begin{array}{l}-0.1028 * * \\
{[0.028]}\end{array}$ & $\begin{array}{l}-0.0892^{* *} \\
{[0.039]}\end{array}$ & $\begin{array}{l}-0.0982 * * \\
{[0.035]}\end{array}$ & $\begin{array}{l}-0.0981^{* *} \\
{[0.035]}\end{array}$ \\
\hline Electricity, Gas, Steam & $\begin{array}{l}-0.0684^{*} \\
{[0.061]}\end{array}$ & $\begin{array}{l}-0.0312 \\
{[0.393]}\end{array}$ & $\begin{array}{l}0.0008 \\
{[0.980]}\end{array}$ & $\begin{array}{l}-0.0148 \\
{[0.683]}\end{array}$ & $\begin{array}{l}-0.0028 \\
{[0.939]}\end{array}$ & $\begin{array}{l}-0.0996 * * \\
{[0.022]}\end{array}$ & $\begin{array}{l}-0.0647 \\
{[0.138]}\end{array}$ & $\begin{array}{l}-0.0268 \\
{[0.508]}\end{array}$ & $\begin{array}{l}-0.0442 \\
{[0.308]}\end{array}$ & $\begin{array}{l}-0.0346 \\
{[0.427]}\end{array}$ \\
\hline Water Works and Supply & $\begin{array}{l}-0.0799 \\
{[0.122]}\end{array}$ & $\begin{array}{l}-0.0413 \\
{[0.424]}\end{array}$ & $\begin{array}{l}0.0072 \\
{[0.881]}\end{array}$ & $\begin{array}{l}-0.0214 \\
{[0.676]}\end{array}$ & $\begin{array}{l}-0.0095 \\
{[0.853]}\end{array}$ & $\begin{array}{l}-0.0818 \\
{[0.185]}\end{array}$ & $\begin{array}{l}-0.0454 \\
{[0.462]}\end{array}$ & $\begin{array}{l}0.0121 \\
{[0.833]}\end{array}$ & $\begin{array}{l}-0.0214 \\
{[0.728]}\end{array}$ & $\begin{array}{l}-0.0117 \\
{[0.849]}\end{array}$ \\
\hline Construction & $\begin{array}{l}-0.0395^{* * *} \\
{[0.001]}\end{array}$ & $\begin{array}{l}-0.0394 * * * \\
{[0.001]}\end{array}$ & $\begin{array}{l}-0.0176 \\
{[0.106]}\end{array}$ & $\begin{array}{l}-0.0178 \\
{[0.127]}\end{array}$ & $\begin{array}{l}-0.0213^{*} \\
{[0.069]}\end{array}$ & $\begin{array}{l}-0.0217 \\
{[0.121]}\end{array}$ & $\begin{array}{l}-0.0224 \\
{[0.109]}\end{array}$ & $\begin{array}{l}0.0042 \\
{[0.744]}\end{array}$ & $\begin{array}{l}0.0006 \\
{[0.963]}\end{array}$ & $\begin{array}{l}-0.0033 \\
{[0.816]}\end{array}$ \\
\hline Wholesale Trade & $\begin{array}{l}-0.0819^{* *} \\
{[0.029]}\end{array}$ & $\begin{array}{l}-0.0638 * \\
{[0.089]}\end{array}$ & $\begin{array}{l}-0.025 \\
{[0.472]}\end{array}$ & $\begin{array}{l}-0.0491 \\
{[0.188]}\end{array}$ & $\begin{array}{l}-0.0443 \\
{[0.235]}\end{array}$ & $\begin{array}{l}-0.0764 * \\
{[0.088]}\end{array}$ & $\begin{array}{c}-0.0595 \\
{[0.183]}\end{array}$ & $\begin{array}{l}-0.0135 \\
{[0.745]}\end{array}$ & $\begin{array}{l}-0.0426 \\
{[0.340]}\end{array}$ & $\begin{array}{l}-0.0389 \\
{[0.384]}\end{array}$ \\
\hline Restaurants and Hotels & $\begin{array}{l}-0.0274 * \\
{[0.081]}\end{array}$ & $\begin{array}{l}-0.0244 \\
{[0.120]}\end{array}$ & $\begin{array}{l}-0.0082 \\
{[0.575]}\end{array}$ & $\begin{array}{l}0.0044 \\
{[0.778]}\end{array}$ & $\begin{array}{l}0.0015 \\
{[0.922]}\end{array}$ & $\begin{array}{l}-0.0375^{* *} \\
{[0.046]}\end{array}$ & $\begin{array}{l}-0.0344^{*} \\
{[0.067]}\end{array}$ & $\begin{array}{l}-0.0162 \\
{[0.353]}\end{array}$ & $\begin{array}{l}-0.0046 \\
{[0.807]}\end{array}$ & $\begin{array}{l}-0.0069 \\
{[0.715]}\end{array}$ \\
\hline Transport and Storage & $\begin{array}{l}-0.0643^{* * *} \\
{[0.000]}\end{array}$ & $\begin{array}{l}-0.0579 * * * \\
{[0.000]}\end{array}$ & $\begin{array}{l}-0.0225^{* *} \\
{[0.034]}\end{array}$ & $\begin{array}{l}-0.0421 * * * \\
{[0.000]}\end{array}$ & $\begin{array}{l}-0.0417 * * * \\
{[0.000]}\end{array}$ & $\begin{array}{l}-0.0766^{* * *} \\
{[0.000]}\end{array}$ & $\begin{array}{l}-0.0714 * * * \\
{[0.000]}\end{array}$ & $\begin{array}{l}-0.0293^{* *} \\
{[0.021]}\end{array}$ & $\begin{array}{l}-0.0536 * * * \\
{[0.000]}\end{array}$ & $\begin{array}{l}-0.0542 * * * \\
{[0.000]}\end{array}$ \\
\hline Communication & $\begin{array}{l}-0.0985^{* *} \\
{[0.019]}\end{array}$ & $\begin{array}{l}-0.0696 * \\
{[0.096]}\end{array}$ & $\begin{array}{l}-0.0254 \\
{[0.513]}\end{array}$ & $\begin{array}{l}-0.0444 \\
{[0.286]}\end{array}$ & $\begin{array}{l}-0.0368 \\
{[0.377]}\end{array}$ & $\begin{array}{l}-0.1585^{* * *} \\
{[0.002]}\end{array}$ & $\begin{array}{l}-0.1314 * * * \\
{[0.009]}\end{array}$ & $\begin{array}{l}-0.0788 * \\
{[0.089]}\end{array}$ & $\begin{array}{l}-0.1027^{* *} \\
{[0.039]}\end{array}$ & $\begin{array}{l}-0.0966^{*} \\
{[0.053]}\end{array}$ \\
\hline Financial Institutions & $\begin{array}{l}-0.0999 * * * \\
{[0.000]}\end{array}$ & $\begin{array}{l}-0.0581^{* *} \\
{[0.011]}\end{array}$ & $\begin{array}{l}-0.0307 \\
{[0.146]}\end{array}$ & $\begin{array}{l}-0.0489 * * \\
{[0.029]}\end{array}$ & $\begin{array}{l}-0.0337 \\
{[0.139]}\end{array}$ & $\begin{array}{l}-0.1459 * * * \\
{[0.000]}\end{array}$ & $\begin{array}{l}-0.1058^{* * * *} \\
{[0.000]}\end{array}$ & $\begin{array}{l}-0.0736^{* * * *} \\
{[0.004]}\end{array}$ & $\begin{array}{l}-0.0932 * * * \\
{[0.001]}\end{array}$ & $\begin{array}{l}-0.0800^{* * * *} \\
{[0.003]}\end{array}$ \\
\hline Insurance & $\begin{array}{l}-0.1031^{* *} \\
{[0.046]}\end{array}$ & $\begin{array}{l}-0.0694 \\
{[0.185]}\end{array}$ & $\begin{array}{l}-0.0369 \\
{[0.447]}\end{array}$ & $\begin{array}{l}-0.0626 \\
{[0.223]}\end{array}$ & $\begin{array}{l}-0.0504 \\
{[0.334]}\end{array}$ & $\begin{array}{l}-0.1510^{* *} \\
{[0.015]}\end{array}$ & $\begin{array}{l}-0.1180^{*} \\
{[0.059]}\end{array}$ & $\begin{array}{l}-0.0796 \\
{[0.170]}\end{array}$ & $\begin{array}{l}-0.1091 * \\
{[0.076]}\end{array}$ & $\begin{array}{l}-0.0979 \\
{[0.116]}\end{array}$ \\
\hline Real estate \& Business & $\begin{array}{l}-0.0582^{* * *} \\
{[0.001]}\end{array}$ & $\begin{array}{l}-0.0402^{* *} \\
{[0.019]}\end{array}$ & $\begin{array}{l}-0.0149 \\
{[0.346]}\end{array}$ & $\begin{array}{l}-0.0328 * \\
{[0.052]}\end{array}$ & $\begin{array}{l}-0.0266 \\
{[0.119]}\end{array}$ & $\begin{array}{l}-0.0430 * * \\
{[0.034]}\end{array}$ & $\begin{array}{l}-0.0271 \\
{[0.184]}\end{array}$ & $\begin{array}{l}0.0028 \\
{[0.884]}\end{array}$ & $\begin{array}{l}-0.0167 \\
{[0.409]}\end{array}$ & $\begin{array}{l}-0.0126 \\
{[0.535]}\end{array}$ \\
\hline Public Administration & $\begin{array}{l}-0.1071^{* * *} \\
{[0.000]}\end{array}$ & $\begin{array}{l}-0.0766^{* * * *} \\
{[0.000]}\end{array}$ & $\begin{array}{l}-0.0227 \\
{[0.107]}\end{array}$ & $\begin{array}{l}-0.0529 * * * \\
{[0.000]}\end{array}$ & $\begin{array}{l}-0.0445^{* * *} \\
{[0.004]}\end{array}$ & $\begin{array}{l}-0.1159 * * * \\
{[0.000]}\end{array}$ & $\begin{array}{l}-0.0871^{* * * *} \\
{[0.000]}\end{array}$ & $\begin{array}{l}-0.0231 \\
{[0.169]}\end{array}$ & $\begin{array}{l}-0.0598 * * * \\
{[0.001]}\end{array}$ & $\begin{array}{l}-0.0531 * * * \\
{[0.004]}\end{array}$ \\
\hline Sanity & $\begin{array}{l}-0.1179 * * \\
{[0.022]}\end{array}$ & $\begin{array}{l}-0.0771 \\
{[0.135]}\end{array}$ & $\begin{array}{l}-0.0284 \\
{[0.553]}\end{array}$ & $\begin{array}{l}-0.0598 \\
{[0.244]}\end{array}$ & $\begin{array}{l}-0.0467 \\
{[0.363]}\end{array}$ & $\begin{array}{l}-0.0365 \\
{[0.554]}\end{array}$ & $\begin{array}{l}0.002 \\
{[0.974]}\end{array}$ & $\begin{array}{l}0.0599 \\
{[0.295]}\end{array}$ & $\begin{array}{l}0.0235 \\
{[0.701]}\end{array}$ & $\begin{array}{l}0.0342 \\
{[0.578]}\end{array}$ \\
\hline Social and Community Services & $\begin{array}{l}-0.0766^{* * * *} \\
{[0.000]}\end{array}$ & $\begin{array}{l}-0.0454^{* * * *} \\
{[0.001]}\end{array}$ & $\begin{array}{l}-0.0105 \\
{[0.404]}\end{array}$ & $\begin{array}{l}-0.0261 * \\
{[0.052]}\end{array}$ & $\begin{array}{l}-0.0168 \\
{[0.220]}\end{array}$ & $\begin{array}{l}-0.0836^{* * * *} \\
{[0.000]}\end{array}$ & $\begin{array}{l}-0.0541^{* * *} \\
{[0.001]}\end{array}$ & $\begin{array}{l}-0.0128 \\
{[0.395]}\end{array}$ & $\begin{array}{l}-0.0314 * \\
{[0.051]}\end{array}$ & $\begin{array}{l}-0.0237 \\
{[0.146]}\end{array}$ \\
\hline Recreation and Culture & $\begin{array}{l}-0.0644^{* *} \\
{[0.015]}\end{array}$ & $\begin{array}{l}-0.0467 * \\
{[0.080]}\end{array}$ & $\begin{array}{l}-0.0283 \\
{[0.251]}\end{array}$ & $\begin{array}{l}-0.022 \\
{[0.405]}\end{array}$ & $\begin{array}{l}-0.0181 \\
{[0.497]}\end{array}$ & $\begin{array}{l}-0.0890^{* * *} \\
{[0.005]}\end{array}$ & $\begin{array}{l}-0.0713^{* *} \\
{[0.025]}\end{array}$ & $\begin{array}{l}-0.0495^{*} \\
{[0.094]}\end{array}$ & $\begin{array}{l}-0.0452 \\
{[0.153]}\end{array}$ & $\begin{array}{l}-0.0409 \\
{[0.200]}\end{array}$ \\
\hline Household and Personal Services & $\begin{array}{l}0.0459 * * * \\
{[0.000]}\end{array}$ & $\begin{array}{l}0.0405^{* * *} \\
{[0.000]}\end{array}$ & $\begin{array}{l}0.0237 * * \\
{[0.020]}\end{array}$ & $\begin{array}{l}0.0572 * * * \\
{[0.000]}\end{array}$ & $\begin{array}{l}0.0527 * * * \\
{[0.000]}\end{array}$ & $\begin{array}{l}0.0572^{* * *} \\
{[0.000]}\end{array}$ & $\begin{array}{l}0.0518^{* * *} \\
{[0.000]}\end{array}$ & $\begin{array}{l}0.0316^{* * * *} \\
{[0.009]}\end{array}$ & $\begin{array}{l}0.0690 * * * \\
{[0.000]}\end{array}$ & $\begin{array}{l}0.0648^{* * *} \\
{[0.000]}\end{array}$ \\
\hline International Bodies & $\begin{array}{l}-0.0775 \\
{[0.683]}\end{array}$ & $\begin{array}{l}-0.0277 \\
{[0.883]}\end{array}$ & $\begin{array}{l}0.0275 \\
{[0.875]}\end{array}$ & $\begin{array}{l}-0.0149 \\
{[0.937]}\end{array}$ & $\begin{array}{l}0.0022 \\
{[0.991]}\end{array}$ & $\begin{array}{l}-0.1026 \\
{[0.650]}\end{array}$ & $\begin{array}{l}-0.0561 \\
{[0.804]}\end{array}$ & $\begin{array}{l}0.0095 \\
{[0.964]}\end{array}$ & $\begin{array}{l}-0.038 \\
{[0.866]}\end{array}$ & $\begin{array}{l}-0.0243 \\
{[0.914]}\end{array}$ \\
\hline Family worker & & & & $\begin{array}{l}0.2807 * * * \\
{[0.004]}\end{array}$ & $\begin{array}{l}0.2656^{* * *} \\
{[0.007]}\end{array}$ & & & & $\begin{array}{l}0.3211^{* * *} \\
{[0.006]}\end{array}$ & $\begin{array}{l}0.3084^{* * *} \\
{[0.009]}\end{array}$ \\
\hline Self-employed & & & & $\begin{array}{l}0.1052^{* * *} \\
{[0.000]}\end{array}$ & $\begin{array}{l}0.0915^{* * *} \\
{[0.000]}\end{array}$ & & & & $\begin{array}{l}0.1087 * * * \\
{[0.000]}\end{array}$ & $\begin{array}{l}0.0971^{* * *} \\
{[0.000]}\end{array}$ \\
\hline Informal & & $\begin{array}{l}0.0664 * * * \\
{[0.000]}\end{array}$ & $\begin{array}{l}0.0202^{* * *} \\
{[0.001]}\end{array}$ & & $\begin{array}{l}0.0342^{* * * *} \\
{[0.000]}\end{array}$ & & $\begin{array}{l}0.0626 * * * \\
{[0.000]}\end{array}$ & $\begin{array}{l}0.0072 \\
{[0.342]}\end{array}$ & & $\begin{array}{l}0.0284^{* * *} \\
{[0.001]}\end{array}$ \\
\hline Paid below minimum wage & & & $\begin{array}{l}0.3195^{* * *} \\
{[0.000]}\end{array}$ & & & & & $\begin{array}{l}0.3818^{* * * *} \\
{[0.000]}\end{array}$ & & \\
\hline $\mathrm{R}^{2}$ & .106 & .113 & .238 & .122 & .124 & .156 & .160 & .278 & .167 & .168 \\
\hline Observations & 13,035 & 12,943 & 12,932 & 13,035 & 12,943 & 13,035 & 12,943 & 12,932 & 13,035 & 12,943 \\
\hline
\end{tabular}




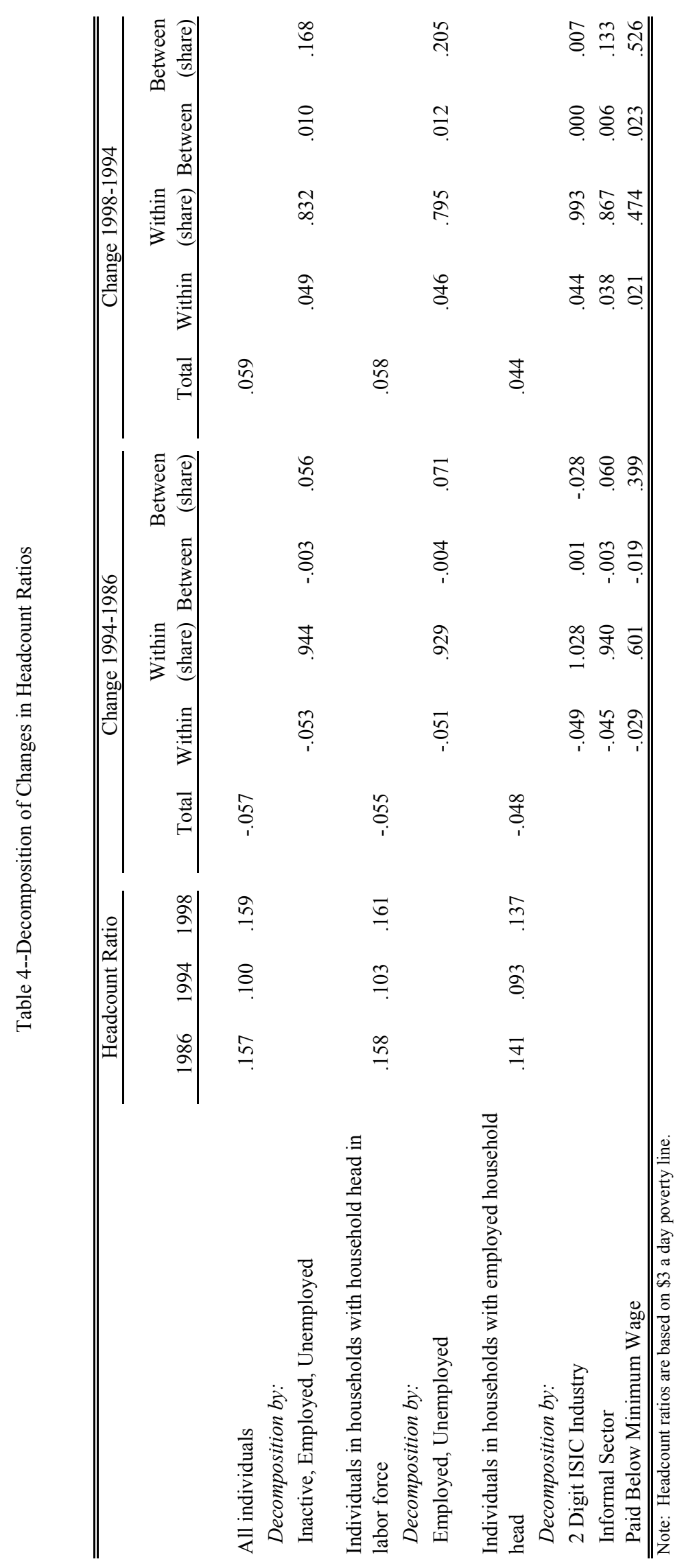


Table 5: Unemployment and Trade Exposure

\begin{tabular}{lll} 
Tariff & .006 & .042 \\
& {$[0.596]$} & {$[0.454]$} \\
Lagged Imports & & $0.00003^{* *}$ \\
& & {$[0.003]$} \\
Lagged Exports & & -0.00002 \\
& & {$[0.773]$} \\
& & \\
Industry Indicators & yes & yes \\
Year Indicators & yes & yes \\
& & \\
$\mathrm{R}^{2}$ & 0.073 & 0.073 \\
Observations & 304,393 & 304,393 \\
\hline \hline
\end{tabular}

Note: P values based on standard errors that are clustered on industry are reported in parenthesis. ** and ${ }^{*}$ indicate 5 and $10 \%$ significance, respectively. All regressions also include controls for age, age squared, gender, whether a person is married, head of the household, education indicators, household size, literacy indicator, whether a person lives in Bogota, whether a person was born in urban area, time in current residency, and the interaction of urban birth with time in current residency. Tariff, lagged imports, and lagged exports are for one-digit ISIC industry of previous employment (or industry in which a person is looking for work for the first time job seekers). Industry indicators are on one-digit ISIC level. Observations refers to number of employed or unemployed individuals (which includes those in industries that did not report tariffs, but where tariffs were likely (and were thus assumed) to be zero). 


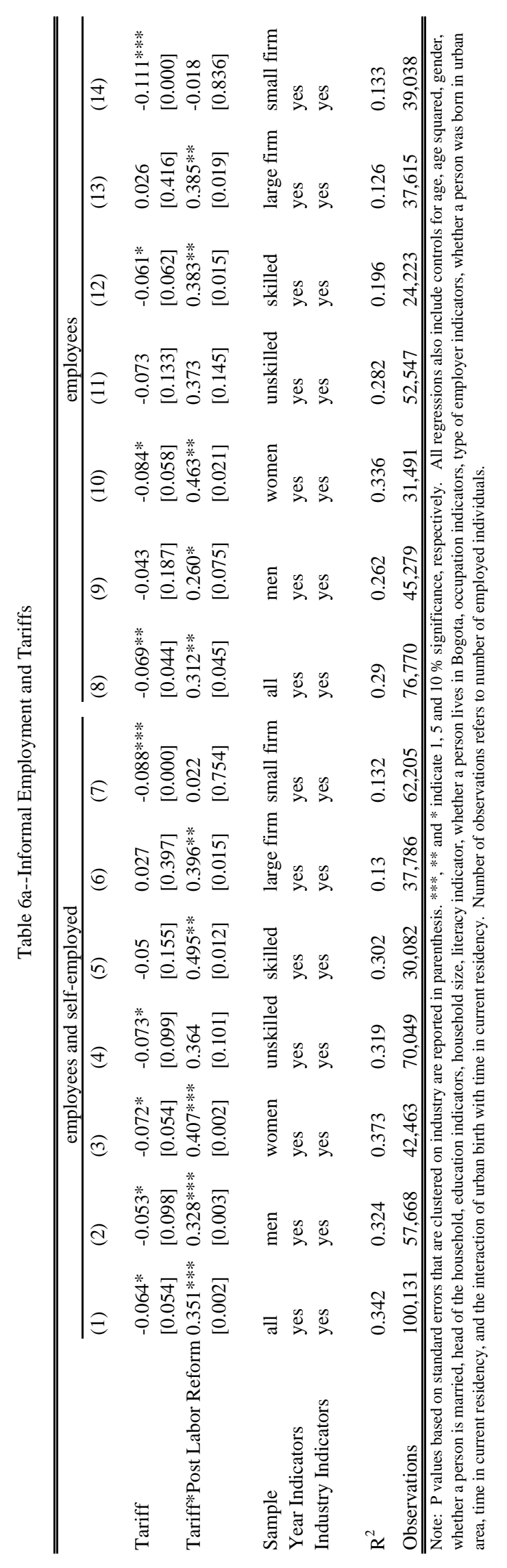




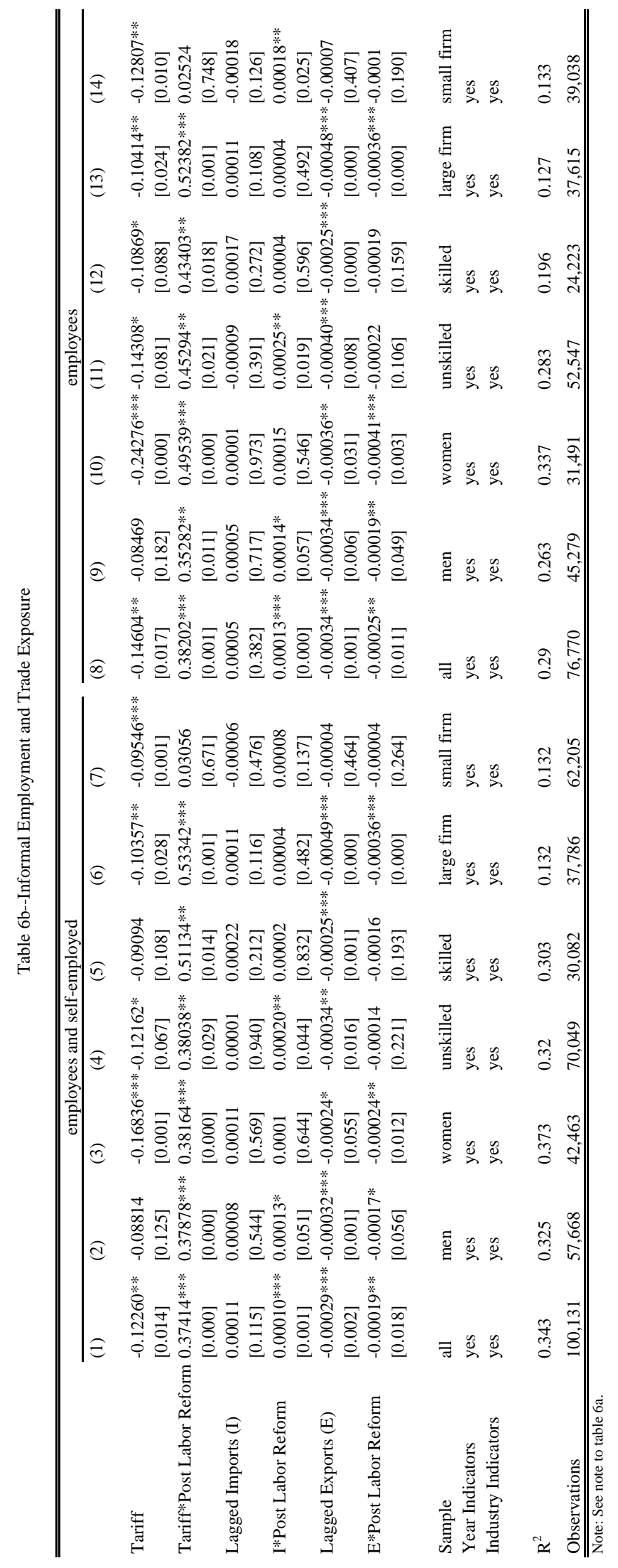




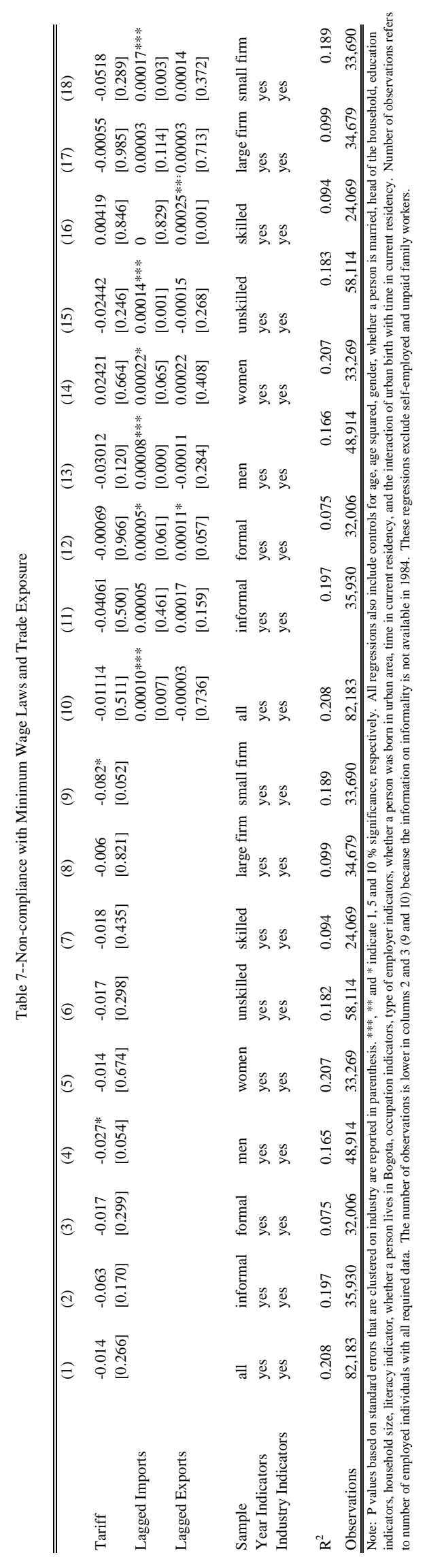




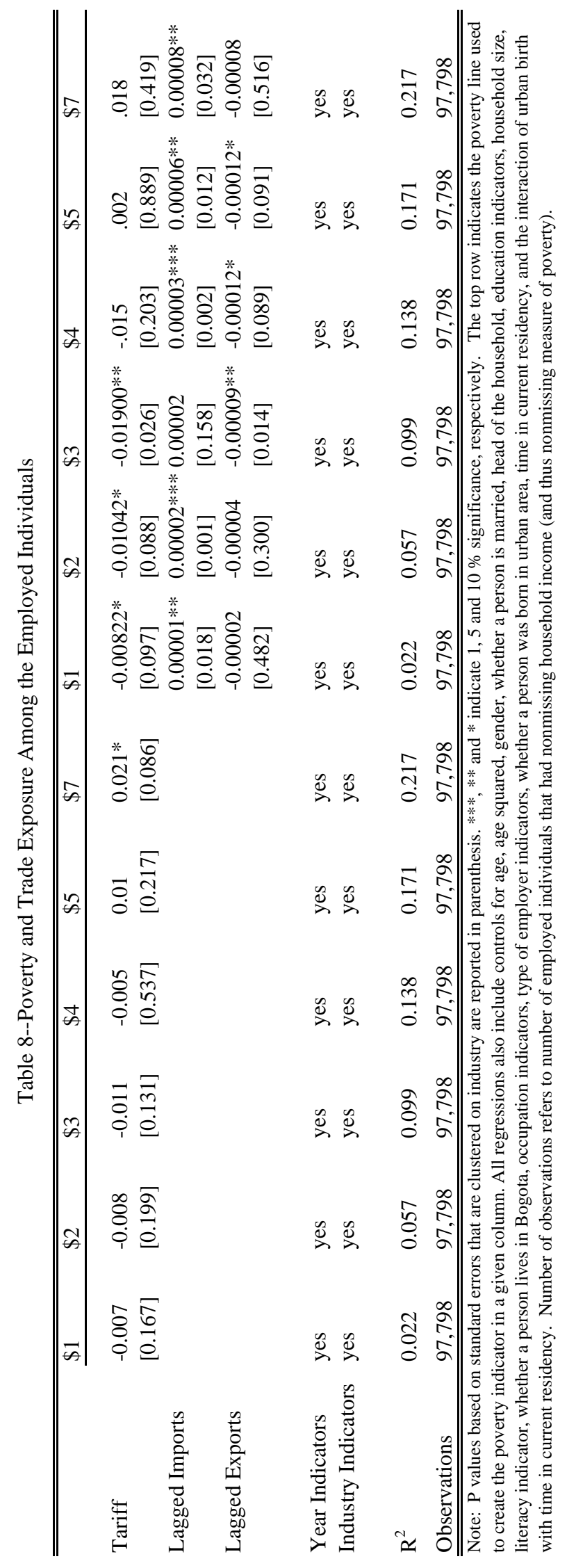


Appendix Table A.1: Correlation of Per Capita Household Income Measures Based on Different Adult Equivalency Scales

\begin{tabular}{lrrrrrrrrrr}
\hline \hline & $\alpha=1$, & $\alpha=0.75$, & $\alpha=0.5$, & $\alpha=1$, & $\alpha=0.75$, & $\alpha=0.5$, & $\alpha=1$, & $\alpha=0.75$, & $\alpha=0.5$, & \\
& $\theta=1$ & $\theta=1$ & $\theta=1$ & $\theta=.75$ & $\theta=.75$ & $\theta=.75$ & $\theta=.5$ & $\theta=.5$ & $\theta=.5$ & OECD \\
$\alpha=1, \theta=1$ & 1.00 & & & & & & & & & \\
$\alpha=0.75, \theta=1$ & 1.00 & 1.00 & & & & & & & & \\
$\alpha=0.5, \theta=1$ & .99 & 1.00 & 1.00 & & & & & & & \\
$\alpha=1, \theta=.75$ & .98 & .99 & .99 & 1.00 & & & & & & \\
$\alpha=0.75, \theta=.75$ & .98 & .98 & .99 & 1.00 & 1.00 & & & & & \\
$\alpha=0.5, \theta=.75$ & .97 & .98 & .98 & 1.00 & 1.00 & 1.00 & & & & \\
$\alpha=1, \theta=.5$ & .93 & .94 & .94 & .98 & .99 & .99 & 1.00 & & & \\
$\alpha=0.75, \theta=.5$ & .93 & .94 & .94 & .98 & .98 & .99 & 1.00 & 1.00 & & \\
$\alpha=0.5, \theta=.5$ & .92 & .93 & .94 & .98 & .98 & .99 & 1.00 & 1.00 & 1.00 & \\
OECD & .99 & .99 & .99 & 1.00 & 1.00 & 1.00 & .97 & .97 & .97 & 1.00 \\
\hline \hline
\end{tabular}


Appendix Table A.2: Sensitivity of Headcount Ratios to Adult-Equivalency Scales

$\begin{array}{llllllll}1984 & 1986 & 1988 & 1990 & 1992 & 1994 & 1996 & 1998\end{array}$

$\$ 1$ per day poverty line

$\begin{array}{rrrrrrrrrr}\alpha & \theta & & & & & & & \\ 1 & 1 & .025 & .025 & .018 & .014 & .018 & .011 & .022 & .028 \\ 0.75 & 1 & .021 & .023 & .016 & .012 & .015 & .010 & .020 & .024 \\ 0.5 & 1 & .019 & .020 & .013 & .011 & .013 & .009 & .018 & .022 \\ 1 & 0.75 & .016 & .018 & .011 & .010 & .012 & .008 & .017 & .019 \\ 0.75 & 0.75 & .015 & .017 & .011 & .009 & .011 & .008 & .015 & .019 \\ 0.5 & 0.75 & .014 & .015 & .010 & .008 & .010 & .007 & .014 & .017 \\ 1 & 0.5 & .012 & .014 & .009 & .007 & .009 & .007 & .014 & .015 \\ 0.75 & 0.5 & .012 & .013 & .009 & .007 & .009 & .007 & .013 & .015 \\ 0.5 & 0.5 & .012 & .013 & .009 & .006 & .008 & .007 & .013 & .014 \\ \text { ECD } & & .017 & .018 & .011 & .010 & .011 & .008 & .017 & .020\end{array}$

\begin{tabular}{|c|c|c|c|c|c|c|c|c|c|}
\hline \multicolumn{10}{|c|}{$\$ 2$ per day poverty line } \\
\hline$\alpha$ & $\theta$ & & & & & & & & \\
\hline 1 & 1 & .069 & .067 & .057 & .051 & .058 & .037 & .055 & .073 \\
\hline 0.75 & 1 & .054 & .055 & .043 & .038 & .043 & .028 & .045 & .058 \\
\hline 0.5 & 1 & .041 & .042 & .034 & .026 & .035 & .020 & .038 & .048 \\
\hline 1 & 0.75 & .032 & .035 & .028 & .020 & .027 & .016 & .031 & .036 \\
\hline 0.75 & 0.75 & .029 & .031 & .023 & .017 & .024 & .014 & .027 & .033 \\
\hline 0.5 & 0.75 & .025 & .027 & .020 & .015 & .019 & .013 & .024 & .030 \\
\hline 1 & 0.5 & .021 & .023 & .016 & .013 & .015 & .011 & .021 & .025 \\
\hline 0.75 & 0.5 & .020 & .022 & .015 & .013 & .014 & .011 & .020 & .024 \\
\hline 0.5 & 0.5 & .018 & .020 & .013 & .012 & .013 & .010 & .019 & .023 \\
\hline OECD & & .034 & .035 & .028 & .020 & .027 & .016 & .031 & .038 \\
\hline
\end{tabular}


Appendix Table A.3a: Poverty and Household Head Characteristics for Households with Employed Head (\$1 and \$2 per day poverty line)

\begin{tabular}{|c|c|c|c|c|c|c|c|c|c|c|}
\hline & \multicolumn{5}{|c|}{ \$1 a day poverty line } & \multicolumn{5}{|c|}{ \$ \$2 a day poverty line } \\
\hline & (1) & (2) & (3) & (4) & (5) & $\overline{(1)}$ & (2) & (3) & (4) & (5) \\
\hline Agriculture and Hunting & $\begin{array}{l}-0.0018 \\
{[0.824]}\end{array}$ & $\begin{array}{l}-0.0006 \\
{[0.942]}\end{array}$ & $\begin{array}{l}0.004 \\
{[0.624]}\end{array}$ & $\begin{array}{l}0.0122 \\
{[0.140]}\end{array}$ & $\begin{array}{l}0.0122 \\
{[0.143]}\end{array}$ & $\begin{array}{l}-0.0293 * * \\
{[0.035]}\end{array}$ & $\begin{array}{l}-0.0269 * \\
{[0.054]}\end{array}$ & $\begin{array}{l}-0.0135 \\
{[0.301]}\end{array}$ & $\begin{array}{l}0.0008 \\
{[0.957]}\end{array}$ & $\begin{array}{l}-0.0007 \\
{[0.957]}\end{array}$ \\
\hline Forestry and logging & $\begin{array}{l}-0.0368 \\
{[0.500]}\end{array}$ & $\begin{array}{l}-0.0304 \\
{[0.577]}\end{array}$ & $\begin{array}{l}-0.0205 \\
{[0.700]}\end{array}$ & $\begin{array}{l}-0.0135 \\
{[0.804]}\end{array}$ & $\begin{array}{l}-0.0127 \\
{[0.814]}\end{array}$ & $\begin{array}{l}-0.1208 \\
{[0.189]}\end{array}$ & $\begin{array}{l}-0.1055 \\
{[0.250]}\end{array}$ & $\begin{array}{l}-0.0767 \\
{[0.371]}\end{array}$ & $\begin{array}{l}-0.0708 \\
{[0.436]}\end{array}$ & $\begin{array}{l}-0.0693 \\
{[0.446]}\end{array}$ \\
\hline Fishing & $\begin{array}{l}-0.0401 \\
{[0.503]}\end{array}$ & $\begin{array}{l}-0.0434 \\
{[0.467]}\end{array}$ & $\begin{array}{l}-0.0425 \\
{[0.465]}\end{array}$ & $\begin{array}{l}-0.0488 \\
{[0.411]}\end{array}$ & $\begin{array}{l}-0.0492 \\
{[0.407]}\end{array}$ & $\begin{array}{l}0.0689 \\
{[0.494]}\end{array}$ & $\begin{array}{l}0.0596 \\
{[0.553]}\end{array}$ & $\begin{array}{l}0.0629 \\
{[0.503]}\end{array}$ & $\begin{array}{l}0.0504 \\
{[0.613]}\end{array}$ & $\begin{array}{l}0.0479 \\
{[0.631]}\end{array}$ \\
\hline Coal Mining & $\begin{array}{l}-0.0269 \\
{[0.369]}\end{array}$ & $\begin{array}{l}-0.0179 \\
{[0.551]}\end{array}$ & $\begin{array}{l}-0.01 \\
{[0.734]}\end{array}$ & $\begin{array}{l}-0.0073 \\
{[0.807]}\end{array}$ & $\begin{array}{l}-0.0053 \\
{[0.859]}\end{array}$ & $\begin{array}{l}-0.0894 * \\
{[0.077]}\end{array}$ & $\begin{array}{l}-0.0676 \\
{[0.180]}\end{array}$ & $\begin{array}{l}-0.0451 \\
{[0.339]}\end{array}$ & $\begin{array}{l}-0.0474 \\
{[0.343]}\end{array}$ & $\begin{array}{l}-0.0419 \\
{[0.403]}\end{array}$ \\
\hline Petroleum and Natural Gas & $\begin{array}{l}-0.0209 \\
{[0.372]}\end{array}$ & $\begin{array}{l}-0.0162 \\
{[0.489]}\end{array}$ & $\begin{array}{l}-0.0034 \\
{[0.883]}\end{array}$ & $\begin{array}{l}-0.0018 \\
{[0.939]}\end{array}$ & $\begin{array}{l}-0.0014 \\
{[0.952]}\end{array}$ & $\begin{array}{l}-0.0710^{*} \\
{[0.072]}\end{array}$ & $\begin{array}{l}-0.0596 \\
{[0.130]}\end{array}$ & $\begin{array}{l}-0.0235 \\
{[0.523]}\end{array}$ & $\begin{array}{l}-0.0301 \\
{[0.442]}\end{array}$ & $\begin{array}{l}-0.0294 \\
{[0.452]}\end{array}$ \\
\hline Metal Ore Mining & $\begin{array}{l}-0.0251 \\
{[0.791]}\end{array}$ & $\begin{array}{l}-0.0283 \\
{[0.764]}\end{array}$ & $\begin{array}{l}-0.0017 \\
{[0.985]}\end{array}$ & $\begin{array}{l}0.0015 \\
{[0.988]}\end{array}$ & $\begin{array}{l}-0.0013 \\
{[0.989]}\end{array}$ & $\begin{array}{l}-0.0927 \\
{[0.561]}\end{array}$ & $\begin{array}{l}-0.1014 \\
{[0.523]}\end{array}$ & $\begin{array}{l}-0.0268 \\
{[0.857]}\end{array}$ & $\begin{array}{l}-0.0358 \\
{[0.820]}\end{array}$ & $\begin{array}{l}-0.0461 \\
{[0.770]}\end{array}$ \\
\hline Other Mining & $\begin{array}{l}0.0715^{* *} \\
{[0.020]}\end{array}$ & $\begin{array}{l}0.027 \\
{[0.392]}\end{array}$ & $\begin{array}{l}0.0173 \\
{[0.574]}\end{array}$ & $\begin{array}{l}0.0850^{* * * *} \\
{[0.005]}\end{array}$ & $\begin{array}{l}0.036 \\
{[0.251]}\end{array}$ & $\begin{array}{l}0.0435 \\
{[0.401]}\end{array}$ & $\begin{array}{l}0.0096 \\
{[0.856]}\end{array}$ & $\begin{array}{l}-0.0172 \\
{[0.730]}\end{array}$ & $\begin{array}{l}0.0724 \\
{[0.158]}\end{array}$ & $\begin{array}{l}0.0281 \\
{[0.593]}\end{array}$ \\
\hline Food & $\begin{array}{l}-0.0214^{* * * *} \\
{[0.001]}\end{array}$ & $\begin{array}{l}-0.0140 * * \\
{[0.029]}\end{array}$ & $\begin{array}{l}-0.0073 \\
{[0.246]}\end{array}$ & $\begin{array}{l}-0.0036 \\
{[0.578]}\end{array}$ & $\begin{array}{l}-0.0021 \\
{[0.745]}\end{array}$ & $\begin{array}{l}-0.0562 * * * \\
{[0.000]}\end{array}$ & $\begin{array}{l}-0.0384 * * * \\
{[0.000]}\end{array}$ & $\begin{array}{l}-0.0192 * \\
{[0.060]}\end{array}$ & $\begin{array}{l}-0.0181^{*} \\
{[0.094]}\end{array}$ & $\begin{array}{l}-0.014 \\
{[0.198]}\end{array}$ \\
\hline Textile, Apparel, Leather & $\begin{array}{l}-0.0209^{* * *} \\
{[0.000]}\end{array}$ & $\begin{array}{l}-0.0167 * * * \\
{[0.001]}\end{array}$ & $\begin{array}{l}-0.0125^{* *} \\
{[0.011]}\end{array}$ & $\begin{array}{l}-0.0084^{*} \\
{[0.095]}\end{array}$ & $\begin{array}{l}-0.0077 \\
{[0.130]}\end{array}$ & $\begin{array}{l}-0.0623^{* * *} \\
{[0.000]}\end{array}$ & $\begin{array}{l}-0.0532^{* * *} \\
{[0.000]}\end{array}$ & $\begin{array}{l}-0.0414^{* * *} \\
{[0.000]}\end{array}$ & $\begin{array}{l}-0.0355^{* * * *} \\
{[0.000]}\end{array}$ & $\begin{array}{l}-0.0348^{* * *} \\
{[0.000]}\end{array}$ \\
\hline Wood & $\begin{array}{l}-0.0157^{*} \\
{[0.057]}\end{array}$ & $\begin{array}{l}-0.0152^{*} \\
{[0.067]}\end{array}$ & $\begin{array}{l}-0.0101 \\
{[0.213]}\end{array}$ & $\begin{array}{l}-0.005 \\
{[0.546]}\end{array}$ & $\begin{array}{l}-0.0052 \\
{[0.527]}\end{array}$ & $\begin{array}{l}-0.0459^{* * * *} \\
{[0.001]}\end{array}$ & $\begin{array}{l}-0.0448^{* * * *} \\
{[0.001]}\end{array}$ & $\begin{array}{l}-0.0302 * * \\
{[0.021]}\end{array}$ & $\begin{array}{l}-0.0229 * \\
{[0.098]}\end{array}$ & $\begin{array}{l}-0.0244^{*} \\
{[0.079]}\end{array}$ \\
\hline Paper & $\begin{array}{l}0.0013 \\
{[0.904]}\end{array}$ & $\begin{array}{l}0.0092 \\
{[0.413]}\end{array}$ & $\begin{array}{l}0.0158 \\
{[0.149]}\end{array}$ & $\begin{array}{l}0.0179 \\
{[0.110]}\end{array}$ & $\begin{array}{l}0.0196^{*} \\
{[0.080]}\end{array}$ & $\begin{array}{l}-0.0522 * * * \\
{[0.006]}\end{array}$ & $\begin{array}{l}-0.0332 * \\
{[0.079]}\end{array}$ & $\begin{array}{l}-0.0143 \\
{[0.419]}\end{array}$ & $\begin{array}{l}-0.0168 \\
{[0.371]}\end{array}$ & $\begin{array}{l}-0.0119 \\
{[0.526]}\end{array}$ \\
\hline Chemical & $\begin{array}{l}-0.0128 \\
{[0.151]}\end{array}$ & $\begin{array}{l}-0.0014 \\
{[0.874]}\end{array}$ & $\begin{array}{l}0.0044 \\
{[0.617]}\end{array}$ & $\begin{array}{l}0.006 \\
{[0.506]}\end{array}$ & $\begin{array}{l}0.0089 \\
{[0.327]}\end{array}$ & $\begin{array}{l}-0.0545^{* * *} \\
{[0.000]}\end{array}$ & $\begin{array}{l}-0.0268 * \\
{[0.079]}\end{array}$ & $\begin{array}{l}-0.0101 \\
{[0.479]}\end{array}$ & $\begin{array}{l}-0.0146 \\
{[0.330]}\end{array}$ & $\begin{array}{l}-0.0059 \\
{[0.698]}\end{array}$ \\
\hline Non-Metallic Mineral Products & $\begin{array}{l}-0.0168 \\
{[0.120]}\end{array}$ & $\begin{array}{l}-0.0074 \\
{[0.497]}\end{array}$ & $\begin{array}{l}-0.0056 \\
{[0.598]}\end{array}$ & $\begin{array}{l}0.0022 \\
{[0.837]}\end{array}$ & $\begin{array}{l}0.0044 \\
{[0.688]}\end{array}$ & $\begin{array}{l}-0.0344^{*} \\
{[0.059]}\end{array}$ & $\begin{array}{l}-0.0112 \\
{[0.543]}\end{array}$ & $\begin{array}{l}-0.0057 \\
{[0.740]}\end{array}$ & $\begin{array}{l}0.0064 \\
{[0.726]}\end{array}$ & $\begin{array}{l}0.013 \\
{[0.478]}\end{array}$ \\
\hline Basic Metal Industry & $\begin{array}{l}-0.0278 \\
{[0.172]}\end{array}$ & $\begin{array}{l}-0.0197 \\
{[0.331]}\end{array}$ & $\begin{array}{l}-0.0129 \\
{[0.516]}\end{array}$ & $\begin{array}{l}-0.0107 \\
{[0.596]}\end{array}$ & $\begin{array}{l}-0.009 \\
{[0.658]}\end{array}$ & $\begin{array}{l}-0.0684^{* *} \\
{[0.046]}\end{array}$ & $\begin{array}{l}-0.0489 \\
{[0.152]}\end{array}$ & $\begin{array}{l}-0.0293 \\
{[0.359]}\end{array}$ & $\begin{array}{l}-0.0319 \\
{[0.346]}\end{array}$ & $\begin{array}{l}-0.0269 \\
{[0.428]}\end{array}$ \\
\hline Machinery and Equipment & $\begin{array}{l}-0.0187 * * * \\
{[0.008]}\end{array}$ & $\begin{array}{l}-0.011 \\
{[0.122]}\end{array}$ & $\begin{array}{l}-0.0029 \\
{[0.673]}\end{array}$ & $\begin{array}{l}-0.0012 \\
{[0.865]}\end{array}$ & $\begin{array}{l}0.0004 \\
{[0.954]}\end{array}$ & $\begin{array}{l}-0.0664 * * * \\
{[0.000]}\end{array}$ & $\begin{array}{l}-0.0479 * * * \\
{[0.000]}\end{array}$ & $\begin{array}{l}-0.0249 * * \\
{[0.026]}\end{array}$ & $\begin{array}{l}-0.0290 * * \\
{[0.015]}\end{array}$ & $\begin{array}{l}-0.0245^{* *} \\
{[0.041]}\end{array}$ \\
\hline Other Manufacturing & $\begin{array}{l}-0.0123 \\
{[0.441]}\end{array}$ & $\begin{array}{l}-0.0112 \\
{[0.480]}\end{array}$ & $\begin{array}{l}-0.0088 \\
{[0.573]}\end{array}$ & $\begin{array}{l}-0.0098 \\
{[0.536]}\end{array}$ & $\begin{array}{l}-0.0095 \\
{[0.547]}\end{array}$ & $\begin{array}{l}-0.0517^{*} \\
{[0.054]}\end{array}$ & $\begin{array}{l}-0.0497 * \\
{[0.063]}\end{array}$ & $\begin{array}{l}-0.0425^{*} \\
{[0.090]}\end{array}$ & $\begin{array}{l}-0.0464^{*} \\
{[0.081]}\end{array}$ & $\begin{array}{l}-0.0462 * \\
{[0.082]}\end{array}$ \\
\hline Electricity, Gas, Steam & $\begin{array}{l}-0.0225 \\
{[0.130]}\end{array}$ & $\begin{array}{l}-0.0113 \\
{[0.449]}\end{array}$ & $\begin{array}{l}-0.0042 \\
{[0.774]}\end{array}$ & $\begin{array}{l}-0.0026 \\
{[0.863]}\end{array}$ & $\begin{array}{l}0.0001 \\
{[0.996]}\end{array}$ & $\begin{array}{l}-0.0602 * * \\
{[0.016]}\end{array}$ & $\begin{array}{l}-0.0327 \\
{[0.191]}\end{array}$ & $\begin{array}{l}-0.0124 \\
{[0.596]}\end{array}$ & $\begin{array}{l}-0.0176 \\
{[0.479]}\end{array}$ & $\begin{array}{l}-0.0096 \\
{[0.701]}\end{array}$ \\
\hline Water Works and Supply & $\begin{array}{l}-0.0286 \\
{[0.174]}\end{array}$ & $\begin{array}{l}-0.0169 \\
{[0.423]}\end{array}$ & $\begin{array}{l}-0.0062 \\
{[0.763]}\end{array}$ & $\begin{array}{l}-0.0068 \\
{[0.744]}\end{array}$ & $\begin{array}{l}-0.0042 \\
{[0.841]}\end{array}$ & $\begin{array}{l}-0.0415 \\
{[0.241]}\end{array}$ & $\begin{array}{l}-0.0129 \\
{[0.717]}\end{array}$ & $\begin{array}{l}0.0178 \\
{[0.592]}\end{array}$ & $\begin{array}{l}0.0049 \\
{[0.889]}\end{array}$ & $\begin{array}{l}0.013 \\
{[0.711]}\end{array}$ \\
\hline Construction & $\begin{array}{l}-0.0173 * * * \\
{[0.000]}\end{array}$ & $\begin{array}{l}-0.0166 * * * \\
{[0.001]}\end{array}$ & $\begin{array}{l}-0.0115^{* *} \\
{[0.014]}\end{array}$ & $\begin{array}{l}-0.0092 * \\
{[0.054]}\end{array}$ & $\begin{array}{l}-0.0093^{*} \\
{[0.052]}\end{array}$ & $\begin{array}{l}-0.0446 * * * \\
{[0.000]}\end{array}$ & $\begin{array}{l}-0.0444 * * * \\
{[0.000]}\end{array}$ & $\begin{array}{l}-0.0304^{* * * *} \\
{[0.000]}\end{array}$ & $\begin{array}{l}-0.0274 * * * \\
{[0.001]}\end{array}$ & $\begin{array}{l}-0.0296 * * * \\
{[0.000]}\end{array}$ \\
\hline Wholesale Trade & $\begin{array}{l}-0.0104 \\
{[0.496]}\end{array}$ & $\begin{array}{l}-0.0049 \\
{[0.750]}\end{array}$ & $\begin{array}{l}0.0038 \\
{[0.800]}\end{array}$ & $\begin{array}{l}0.0018 \\
{[0.907]}\end{array}$ & $\begin{array}{l}0.0029 \\
{[0.848]}\end{array}$ & $\begin{array}{l}-0.0586^{* *} \\
{[0.023]}\end{array}$ & $\begin{array}{l}-0.0453 * \\
{[0.078]}\end{array}$ & $\begin{array}{l}-0.0207 \\
{[0.388]}\end{array}$ & $\begin{array}{l}-0.0325 \\
{[0.202]}\end{array}$ & $\begin{array}{l}-0.0294 \\
{[0.249]}\end{array}$ \\
\hline Restaurants and Hotels & $\begin{array}{l}-0.0118^{*} \\
{[0.064]}\end{array}$ & $\begin{array}{l}-0.0106 * \\
{[0.097]}\end{array}$ & $\begin{array}{l}-0.0086 \\
{[0.169]}\end{array}$ & $\begin{array}{l}0.0001 \\
{[0.993]}\end{array}$ & $\begin{array}{l}-0.0002 \\
{[0.974]}\end{array}$ & $\begin{array}{l}-0.0334 * * * \\
{[0.002]}\end{array}$ & $\begin{array}{l}-0.0311^{* * * *} \\
{[0.004]}\end{array}$ & $\begin{array}{l}-0.0218^{* *} \\
{[0.031]}\end{array}$ & $\begin{array}{l}-0.0081 \\
{[0.454]}\end{array}$ & $\begin{array}{l}-0.0099 \\
{[0.358]}\end{array}$ \\
\hline Transport and Storage & $\begin{array}{l}-0.0100^{* *} \\
{[0.031]}\end{array}$ & $\begin{array}{l}-0.0079 * \\
{[0.089]}\end{array}$ & $\begin{array}{l}-0.0001 \\
{[0.983]}\end{array}$ & $\begin{array}{l}-0.0018 \\
{[0.702]}\end{array}$ & $\begin{array}{l}-0.0015 \\
{[0.747]}\end{array}$ & $\begin{array}{l}-0.0473^{* * *} \\
{[0.000]}\end{array}$ & $\begin{array}{l}-0.0427 * * * \\
{[0.000]}\end{array}$ & $\begin{array}{l}-0.0203 * * * \\
{[0.006]}\end{array}$ & $\begin{array}{l}-0.0297 * * * \\
{[0.000]}\end{array}$ & $\begin{array}{l}-0.0296 * * * \\
{[0.000]}\end{array}$ \\
\hline Communication & $\begin{array}{l}-0.0223 \\
{[0.191]}\end{array}$ & $\begin{array}{l}-0.0136 \\
{[0.426]}\end{array}$ & $\begin{array}{l}-0.0037 \\
{[0.824]}\end{array}$ & $\begin{array}{l}-0.0022 \\
{[0.897]}\end{array}$ & $\begin{array}{l}-0.0005 \\
{[0.978]}\end{array}$ & $\begin{array}{l}-0.0686^{* *} \\
{[0.017]}\end{array}$ & $\begin{array}{l}-0.0473 * \\
{[0.099]}\end{array}$ & $\begin{array}{l}-0.0193 \\
{[0.473]}\end{array}$ & $\begin{array}{l}-0.0256 \\
{[0.369]}\end{array}$ & $\begin{array}{l}-0.0205 \\
{[0.472]}\end{array}$ \\
\hline Financial Institutions & $\begin{array}{l}-0.0196 * * \\
{[0.032]}\end{array}$ & $\begin{array}{l}-0.0073 \\
{[0.434]}\end{array}$ & $\begin{array}{l}-0.0012 \\
{[0.894]}\end{array}$ & $\begin{array}{l}-0.0006 \\
{[0.948]}\end{array}$ & $\begin{array}{l}0.0024 \\
{[0.792]}\end{array}$ & $\begin{array}{l}-0.0609 * * * \\
{[0.000]}\end{array}$ & $\begin{array}{l}-0.0305 * \\
{[0.051]}\end{array}$ & $\begin{array}{l}-0.0133 \\
{[0.365]}\end{array}$ & $\begin{array}{l}-0.0203 \\
{[0.187]}\end{array}$ & $\begin{array}{l}-0.0107 \\
{[0.493]}\end{array}$ \\
\hline Insurance & $\begin{array}{l}-0.022 \\
{[0.297]}\end{array}$ & $\begin{array}{l}-0.0122 \\
{[0.567]}\end{array}$ & $\begin{array}{l}-0.0051 \\
{[0.807]}\end{array}$ & $\begin{array}{l}-0.0069 \\
{[0.740]}\end{array}$ & $\begin{array}{l}-0.0046 \\
{[0.827]}\end{array}$ & $\begin{array}{l}-0.0614 * \\
{[0.084]}\end{array}$ & $\begin{array}{l}-0.0373 \\
{[0.299]}\end{array}$ & $\begin{array}{l}-0.0168 \\
{[0.617]}\end{array}$ & $\begin{array}{l}-0.0292 \\
{[0.407]}\end{array}$ & $\begin{array}{l}-0.0218 \\
{[0.541]}\end{array}$ \\
\hline Real estate \& Business & $\begin{array}{l}-0.0211^{* * * *} \\
{[0.002]}\end{array}$ & $\begin{array}{l}-0.0157 * * \\
{[0.024]}\end{array}$ & $\begin{array}{l}-0.0101 \\
{[0.138]}\end{array}$ & $\begin{array}{l}-0.0116^{*} \\
{[0.092]}\end{array}$ & $\begin{array}{l}-0.0102 \\
{[0.140]}\end{array}$ & $\begin{array}{l}-0.0647 * * * \\
{[0.000]}\end{array}$ & $\begin{array}{l}-0.0519^{* * * *} \\
{[0.000]}\end{array}$ & $\begin{array}{l}-0.0359 * * * \\
{[0.001]}\end{array}$ & $\begin{array}{l}-0.0444^{* * * *} \\
{[0.000]}\end{array}$ & $\begin{array}{l}-0.0408^{* * * *} \\
{[0.000]}\end{array}$ \\
\hline Public Administration & $\begin{array}{l}-0.0237 * * * \\
{[0.000]}\end{array}$ & $\begin{array}{l}-0.0144^{* *} \\
{[0.020]}\end{array}$ & $\begin{array}{l}-0.0023 \\
{[0.699]}\end{array}$ & $\begin{array}{l}-0.0035 \\
{[0.566]}\end{array}$ & $\begin{array}{l}-0.0016 \\
{[0.797]}\end{array}$ & $\begin{array}{l}-0.0706^{* * *} \\
{[0.000]}\end{array}$ & $\begin{array}{l}-0.0479 * * * \\
{[0.000]}\end{array}$ & $\begin{array}{l}-0.0138 \\
{[0.156]}\end{array}$ & $\begin{array}{l}-0.0275^{* * *} \\
{[0.008]}\end{array}$ & $\begin{array}{l}-0.0218^{* *} \\
{[0.037]}\end{array}$ \\
\hline Sanity & $\begin{array}{l}-0.0299 \\
{[0.155]}\end{array}$ & $\begin{array}{l}-0.0174 \\
{[0.407]}\end{array}$ & $\begin{array}{l}-0.0066 \\
{[0.747]}\end{array}$ & $\begin{array}{l}-0.0083 \\
{[0.693]}\end{array}$ & $\begin{array}{l}-0.0053 \\
{[0.800]}\end{array}$ & $\begin{array}{l}-0.0955^{* * * *} \\
{[0.007]}\end{array}$ & $\begin{array}{l}-0.0650 * \\
{[0.066]}\end{array}$ & $\begin{array}{l}-0.0342 \\
{[0.302]}\end{array}$ & $\begin{array}{l}-0.0493 \\
{[0.160]}\end{array}$ & $\begin{array}{l}-0.0403 \\
{[0.252]}\end{array}$ \\
\hline Social and Community Services & $\begin{array}{l}-0.0216^{* * * *} \\
{[0.000]}\end{array}$ & $\begin{array}{l}-0.0123 * * \\
{[0.026]}\end{array}$ & $\begin{array}{l}-0.0045 \\
{[0.402]}\end{array}$ & $\begin{array}{l}-0.0029 \\
{[0.601]}\end{array}$ & $\begin{array}{l}-0.0009 \\
{[0.877]}\end{array}$ & $\begin{array}{l}-0.0609 * * * \\
{[0.000]}\end{array}$ & $\begin{array}{l}-0.0380^{* * * *} \\
{[0.000]}\end{array}$ & $\begin{array}{l}-0.0160 * \\
{[0.066]}\end{array}$ & $\begin{array}{l}-0.0208^{* *} \\
{[0.024]}\end{array}$ & $\begin{array}{l}-0.0147 \\
{[0.116]}\end{array}$ \\
\hline Recreation and Culture & $\begin{array}{l}-0.0099 \\
{[0.358]}\end{array}$ & $\begin{array}{l}-0.0046 \\
{[0.674]}\end{array}$ & $\begin{array}{l}-0.0006 \\
{[0.958]}\end{array}$ & $\begin{array}{l}0.0058 \\
{[0.591]}\end{array}$ & $\begin{array}{l}0.0068 \\
{[0.528]}\end{array}$ & $\begin{array}{l}-0.0475^{* * *} \\
{[0.009]}\end{array}$ & $\begin{array}{l}-0.0348 * \\
{[0.057]}\end{array}$ & $\begin{array}{l}-0.0232 \\
{[0.175]}\end{array}$ & $\begin{array}{l}-0.0138 \\
{[0.445]}\end{array}$ & $\begin{array}{l}-0.0115 \\
{[0.528]}\end{array}$ \\
\hline Household and Personal Services & $\begin{array}{l}0.0049 \\
{[0.269]}\end{array}$ & $\begin{array}{l}0.0037 \\
{[0.400]}\end{array}$ & $\begin{array}{l}-0.0002 \\
{[0.965]}\end{array}$ & $\begin{array}{l}0.0091 * * \\
{[0.040]}\end{array}$ & $\begin{array}{l}0.0086^{*} \\
{[0.054]}\end{array}$ & $\begin{array}{l}0.004 \\
{[0.593]}\end{array}$ & $\begin{array}{l}0.0004 \\
{[0.956]}\end{array}$ & $\begin{array}{l}-0.0104 \\
{[0.140]}\end{array}$ & $\begin{array}{l}0.0130^{*} \\
{[0.080]}\end{array}$ & $\begin{array}{l}0.0103 \\
{[0.167]}\end{array}$ \\
\hline International Bodies & $\begin{array}{l}-0.0243 \\
{[0.752]}\end{array}$ & $\begin{array}{l}-0.0095 \\
{[0.902]}\end{array}$ & $\begin{array}{l}0.0026 \\
{[0.972]}\end{array}$ & $\begin{array}{l}-0.0011 \\
{[0.989]}\end{array}$ & $\begin{array}{l}0.0025 \\
{[0.974]}\end{array}$ & $\begin{array}{l}-0.0585 \\
{[0.653]}\end{array}$ & $\begin{array}{l}-0.0219 \\
{[0.866]}\end{array}$ & $\begin{array}{l}0.0129 \\
{[0.915]}\end{array}$ & $\begin{array}{l}-0.0087 \\
{[0.946]}\end{array}$ & $\begin{array}{l}0.0026 \\
{[0.984]}\end{array}$ \\
\hline Family worker & & & & $\begin{array}{l}0.0814 * * \\
{[0.042]}\end{array}$ & $\begin{array}{l}0.0785^{* *} \\
{[0.050]}\end{array}$ & & & & $\begin{array}{l}0.2146 * * * \\
{[0.001]}\end{array}$ & $\begin{array}{l}0.2047^{* * *} \\
{[0.002]}\end{array}$ \\
\hline Self-employed & & & & $\begin{array}{l}0.0392^{* * *} \\
{[0.000]}\end{array}$ & $\begin{array}{l}0.0365^{* * *} \\
{[0.000]}\end{array}$ & & & & $\begin{array}{l}0.0837^{* * * *} \\
{[0.000]}\end{array}$ & $\begin{array}{l}0.0746^{* * *} \\
{[0.000]}\end{array}$ \\
\hline Informal & & $\begin{array}{l}0.0197 * * * \\
{[0.000]}\end{array}$ & $\begin{array}{l}0.0091^{* * * *} \\
{[0.001]}\end{array}$ & & $\begin{array}{l}0.0068^{* *} \\
{[0.019]}\end{array}$ & & $\begin{array}{l}0.0492 * * * \\
{[0.000]}\end{array}$ & $\begin{array}{l}0.0198^{* * * *} \\
{[0.000]}\end{array}$ & & $\begin{array}{l}0.0229 * * * \\
{[0.000]}\end{array}$ \\
\hline Paid $b$ & & & $\begin{array}{l}0.0723 * * * \\
{[0.000]}\end{array}$ & & & & & $\begin{array}{l}0.2030^{* * *} \\
{[0.000]}\end{array}$ & & \\
\hline $\begin{array}{l}\mathrm{R}^{2} \\
\text { Observations }\end{array}$ & $\begin{array}{l}.017 \\
13,035\end{array}$ & $\begin{array}{l}.020 \\
12,943\end{array}$ & $\begin{array}{l}.063 \\
12,932\end{array}$ & $\begin{array}{l}.031 \\
13,035\end{array}$ & $\begin{array}{l}.031 \\
12,943\end{array}$ & $\begin{array}{l}.058 \\
13,035\end{array}$ & $\begin{array}{l}.066 \\
12,943\end{array}$ & $\begin{array}{l}.179 \\
12,932\end{array}$ & $\begin{array}{l}.080 \\
13,035\end{array}$ & $\begin{array}{l}.082 \\
12,943\end{array}$ \\
\hline
\end{tabular}


Appendix Table A.3b: Poverty and Household Head Characteristics for Households with Employed Heads (\$5 and \$7 per day poverty line)

\begin{tabular}{|c|c|c|c|c|c|c|c|c|c|c|}
\hline & \multicolumn{5}{|c|}{ \$5 a day poverty line } & \multicolumn{5}{|c|}{ \$7 a day poverty line } \\
\hline & $\overline{(1)}$ & (2) & (3) & (4) & (5) & (1) & (2) & (3) & (4) & (5) \\
\hline Agriculture and Hunting & $\begin{array}{l}-0.0066 \\
{[0.805]}\end{array}$ & $\begin{array}{l}-0.0098 \\
{[0.714]}\end{array}$ & $\begin{array}{l}0.0154 \\
{[0.540]}\end{array}$ & $\begin{array}{l}0.0299 \\
{[0.262]}\end{array}$ & $\begin{array}{l}0.0218 \\
{[0.417]}\end{array}$ & $\begin{array}{l}-0.0293 \\
{[0.279]}\end{array}$ & $\begin{array}{l}-0.0309 \\
{[0.256]}\end{array}$ & $\begin{array}{l}-0.009 \\
{[0.730]}\end{array}$ & $\begin{array}{l}-0.0001 \\
{[0.998]}\end{array}$ & $\begin{array}{l}-0.0072 \\
{[0.792]}\end{array}$ \\
\hline Forestry and logging & $\begin{array}{l}0.0221 \\
{[0.900]}\end{array}$ & $\begin{array}{l}0.04 \\
{[0.820]}\end{array}$ & $\begin{array}{l}0.0947 \\
{[0.566]}\end{array}$ & $\begin{array}{l}0.0828 \\
{[0.636]}\end{array}$ & $\begin{array}{l}0.0838 \\
{[0.633]}\end{array}$ & $\begin{array}{l}-0.1113 \\
{[0.534]}\end{array}$ & $\begin{array}{l}-0.0941 \\
{[0.599]}\end{array}$ & $\begin{array}{l}-0.0472 \\
{[0.783]}\end{array}$ & $\begin{array}{l}-0.0626 \\
{[0.726]}\end{array}$ & $\begin{array}{l}-0.0613 \\
{[0.731]}\end{array}$ \\
\hline Fishing & $\begin{array}{l}-0.0888 \\
{[0.645]}\end{array}$ & $\begin{array}{l}-0.1008 \\
{[0.601]}\end{array}$ & $\begin{array}{l}-0.0951 \\
{[0.599]}\end{array}$ & $\begin{array}{l}-0.1113 \\
{[0.562]}\end{array}$ & $\begin{array}{l}-0.1149 \\
{[0.549]}\end{array}$ & $\begin{array}{l}-0.016 \\
{[0.935]}\end{array}$ & $\begin{array}{l}-0.0273 \\
{[0.889]}\end{array}$ & $\begin{array}{l}-0.0219 \\
{[0.907]}\end{array}$ & $\begin{array}{l}-0.0339 \\
{[0.862]}\end{array}$ & $\begin{array}{l}-0.0378 \\
{[0.847]}\end{array}$ \\
\hline Coal Mining & $\begin{array}{l}-0.1778^{*} \\
{[0.066]}\end{array}$ & $\begin{array}{l}-0.1518 \\
{[0.116]}\end{array}$ & $\begin{array}{l}-0.1092 \\
{[0.228]}\end{array}$ & $\begin{array}{l}-0.1268 \\
{[0.188]}\end{array}$ & $\begin{array}{l}-0.1207 \\
{[0.211]}\end{array}$ & $\begin{array}{l}-0.065 \\
{[0.509]}\end{array}$ & $\begin{array}{l}-0.0397 \\
{[0.686]}\end{array}$ & $\begin{array}{l}-0.0031 \\
{[0.973]}\end{array}$ & $\begin{array}{l}-0.0241 \\
{[0.806]}\end{array}$ & $\begin{array}{l}-0.0164 \\
{[0.867]}\end{array}$ \\
\hline Petroleum and Natural Gas & $\begin{array}{l}-0.1637^{* *} \\
{[0.030]}\end{array}$ & $\begin{array}{l}-0.1499 * * \\
{[0.047]}\end{array}$ & $\begin{array}{l}-0.081 \\
{[0.253]}\end{array}$ & $\begin{array}{l}-0.114 \\
{[0.130]}\end{array}$ & $\begin{array}{l}-0.1133 \\
{[0.133]}\end{array}$ & $\begin{array}{l}-0.1876^{* *} \\
{[0.015]}\end{array}$ & $\begin{array}{l}-0.1742^{* *} \\
{[0.023]}\end{array}$ & $\begin{array}{l}-0.1153 \\
{[0.117]}\end{array}$ & $\begin{array}{l}-0.1477 * \\
{[0.054]}\end{array}$ & $\begin{array}{l}-0.1468 * \\
{[0.056]}\end{array}$ \\
\hline Metal Ore Mining & $\begin{array}{l}-0.4671 \\
{[0.125]}\end{array}$ & $\begin{array}{l}-0.4772 \\
{[0.117]}\end{array}$ & $\begin{array}{l}-0.3349 \\
{[0.241]}\end{array}$ & $\begin{array}{l}-0.398 \\
{[0.190]}\end{array}$ & $\begin{array}{l}-0.4103 \\
{[0.176]}\end{array}$ & $\begin{array}{l}-0.1367 \\
{[0.659]}\end{array}$ & $\begin{array}{l}-0.1471 \\
{[0.635]}\end{array}$ & $\begin{array}{l}-0.0259 \\
{[0.931]}\end{array}$ & $\begin{array}{l}-0.0813 \\
{[0.793]}\end{array}$ & $\begin{array}{l}-0.097 \\
{[0.754]}\end{array}$ \\
\hline Other Mining & $\begin{array}{l}0.3441^{* * *} \\
{[0.001]}\end{array}$ & $\begin{array}{l}0.3538^{* * *} \\
{[0.001]}\end{array}$ & $\begin{array}{l}0.3020^{* * *} \\
{[0.002]}\end{array}$ & $\begin{array}{l}0.3792 * * * \\
{[0.000]}\end{array}$ & $\begin{array}{l}0.3763^{* * *} \\
{[0.000]}\end{array}$ & $\begin{array}{l}0.1780^{*} \\
{[0.078]}\end{array}$ & $\begin{array}{l}0.1875^{*} \\
{[0.070]}\end{array}$ & $\begin{array}{l}0.1442 \\
{[0.146]}\end{array}$ & $\begin{array}{l}0.2062^{* *} \\
{[0.041]}\end{array}$ & $\begin{array}{l}0.2043^{* *} \\
{[0.048]}\end{array}$ \\
\hline Food & $\begin{array}{l}-0.0730^{* * *} \\
{[0.000]}\end{array}$ & $\begin{array}{l}-0.0519^{* *} \\
{[0.013]}\end{array}$ & $\begin{array}{l}-0.0152 \\
{[0.435]}\end{array}$ & $\begin{array}{l}-0.0267 \\
{[0.200]}\end{array}$ & $\begin{array}{l}-0.0223 \\
{[0.287]}\end{array}$ & $\begin{array}{l}-0.0393 * \\
{[0.059]}\end{array}$ & $\begin{array}{l}-0.0213 \\
{[0.315]}\end{array}$ & $\begin{array}{l}0.0102 \\
{[0.614]}\end{array}$ & $\begin{array}{l}-0.0022 \\
{[0.916]}\end{array}$ & $\begin{array}{l}0.0008 \\
{[0.969]}\end{array}$ \\
\hline Textile, Apparel, Leather & $\begin{array}{l}-0.0496 * * * \\
{[0.002]}\end{array}$ & $\begin{array}{l}-0.0369 * * \\
{[0.023]}\end{array}$ & $\begin{array}{l}-0.0143 \\
{[0.347]}\end{array}$ & $\begin{array}{l}-0.0171 \\
{[0.296]}\end{array}$ & $\begin{array}{l}-0.0146 \\
{[0.373]}\end{array}$ & $\begin{array}{l}0.0127 \\
{[0.438]}\end{array}$ & $\begin{array}{l}0.0257 \\
{[0.120]}\end{array}$ & $\begin{array}{l}0.0452 * * * \\
{[0.004]}\end{array}$ & $\begin{array}{l}0.0389 * * \\
{[0.020]}\end{array}$ & $\begin{array}{l}0.0424 * * \\
{[0.011]}\end{array}$ \\
\hline Wood & $\begin{array}{l}0.0137 \\
{[0.607]}\end{array}$ & $\begin{array}{l}0.0168 \\
{[0.530]}\end{array}$ & $\begin{array}{l}0.0445^{*} \\
{[0.076]}\end{array}$ & $\begin{array}{l}0.0417 \\
{[0.117]}\end{array}$ & $\begin{array}{l}0.0414 \\
{[0.122]}\end{array}$ & $\begin{array}{l}0.0124 \\
{[0.647]}\end{array}$ & $\begin{array}{l}0.0139 \\
{[0.608]}\end{array}$ & $\begin{array}{l}0.0379 \\
{[0.146]}\end{array}$ & $\begin{array}{l}0.0349 \\
{[0.199]}\end{array}$ & $\begin{array}{l}0.0324 \\
{[0.235]}\end{array}$ \\
\hline Paper & $\begin{array}{l}-0.1134^{* * *} \\
{[0.002]}\end{array}$ & $\begin{array}{l}-0.0905^{* *} \\
{[0.013]}\end{array}$ & $\begin{array}{l}-0.0545 \\
{[0.109]}\end{array}$ & $\begin{array}{l}-0.0704 * \\
{[0.052]}\end{array}$ & $\begin{array}{l}-0.0647 * \\
{[0.074]}\end{array}$ & $\begin{array}{l}-0.1126 * * * \\
{[0.002]}\end{array}$ & $\begin{array}{l}-0.0903 * * \\
{[0.014]}\end{array}$ & $\begin{array}{l}-0.0593^{*} \\
{[0.093]}\end{array}$ & $\begin{array}{l}-0.0781^{* *} \\
{[0.034]}\end{array}$ & $\begin{array}{l}-0.0710^{*} \\
{[0.055]}\end{array}$ \\
\hline Chemical & $\begin{array}{l}-0.0580^{* *} \\
{[0.043]}\end{array}$ & $\begin{array}{l}-0.0209 \\
{[0.474]}\end{array}$ & $\begin{array}{l}0.0078 \\
{[0.775]}\end{array}$ & $\begin{array}{l}-0.0095 \\
{[0.743]}\end{array}$ & $\begin{array}{l}0.0043 \\
{[0.882]}\end{array}$ & $\begin{array}{l}-0.0511^{*} \\
{[0.080]}\end{array}$ & $\begin{array}{l}-0.0133 \\
{[0.655]}\end{array}$ & $\begin{array}{l}0.0119 \\
{[0.677]}\end{array}$ & $\begin{array}{l}-0.0124 \\
{[0.674]}\end{array}$ & $\begin{array}{l}0.0054 \\
{[0.856]}\end{array}$ \\
\hline Non-Metallic Mineral Products & $\begin{array}{l}0.0383 \\
{[0.272]}\end{array}$ & $\begin{array}{l}0.0698 * * \\
{[0.048]}\end{array}$ & $\begin{array}{l}0.0799 * * \\
{[0.016]}\end{array}$ & $\begin{array}{l}0.0879 * * \\
{[0.012]}\end{array}$ & $\begin{array}{l}0.0990^{* * *} \\
{[0.005]}\end{array}$ & $\begin{array}{l}0.0896^{* *} \\
{[0.012]}\end{array}$ & $\begin{array}{l}0.1156^{* * * *} \\
{[0.001]}\end{array}$ & $\begin{array}{l}0.1246^{* * * *} \\
{[0.000]}\end{array}$ & $\begin{array}{l}0.1293^{* * * *} \\
{[0.000]}\end{array}$ & $\begin{array}{l}0.1374^{* * *} \\
{[0.000]}\end{array}$ \\
\hline Basic Metal Industry & $\begin{array}{l}0.0073 \\
{[0.912]}\end{array}$ & $\begin{array}{l}0.0306 \\
{[0.640]}\end{array}$ & $\begin{array}{l}0.0679 \\
{[0.269]}\end{array}$ & $\begin{array}{l}0.0516 \\
{[0.430]}\end{array}$ & $\begin{array}{l}0.0573 \\
{[0.381]}\end{array}$ & $\begin{array}{l}0.0034 \\
{[0.959]}\end{array}$ & $\begin{array}{l}0.026 \\
{[0.696]}\end{array}$ & $\begin{array}{l}0.058 \\
{[0.363]}\end{array}$ & $\begin{array}{l}0.0389 \\
{[0.558]}\end{array}$ & $\begin{array}{l}0.0459 \\
{[0.490]}\end{array}$ \\
\hline Machinery and Equipment & $\begin{array}{l}-0.0612^{* * *} \\
{[0.007]}\end{array}$ & $\begin{array}{l}-0.0382 * \\
{[0.096]}\end{array}$ & $\begin{array}{l}0.0055 \\
{[0.800]}\end{array}$ & $\begin{array}{l}-0.0158 \\
{[0.490]}\end{array}$ & $\begin{array}{l}-0.01 \\
{[0.666]}\end{array}$ & $\begin{array}{l}-0.02 \\
{[0.386]}\end{array}$ & $\begin{array}{l}0.0019 \\
{[0.934]}\end{array}$ & $\begin{array}{l}0.0394 * \\
{[0.079]}\end{array}$ & $\begin{array}{l}0.0164 \\
{[0.482]}\end{array}$ & $\begin{array}{l}0.0231 \\
{[0.327]}\end{array}$ \\
\hline Other Manufacturing & $\begin{array}{l}-0.0646 \\
{[0.209]}\end{array}$ & $\begin{array}{l}-0.0621 \\
{[0.227]}\end{array}$ & $\begin{array}{l}-0.0484 \\
{[0.315]}\end{array}$ & $\begin{array}{l}-0.0581 \\
{[0.257]}\end{array}$ & $\begin{array}{l}-0.0578 \\
{[0.259]}\end{array}$ & $\begin{array}{l}-0.0432 \\
{[0.410]}\end{array}$ & $\begin{array}{l}-0.0406 \\
{[0.437]}\end{array}$ & $\begin{array}{l}-0.0285 \\
{[0.569]}\end{array}$ & $\begin{array}{l}-0.0379 \\
{[0.468]}\end{array}$ & $\begin{array}{l}-0.0373 \\
{[0.474]}\end{array}$ \\
\hline Electricity, Gas, Steam & $\begin{array}{l}-0.0854^{*} \\
{[0.074]}\end{array}$ & $\begin{array}{l}-0.0523 \\
{[0.276]}\end{array}$ & $\begin{array}{l}-0.0138 \\
{[0.760]}\end{array}$ & $\begin{array}{l}-0.0337 \\
{[0.481]}\end{array}$ & $\begin{array}{l}-0.0243 \\
{[0.612]}\end{array}$ & $\begin{array}{l}-0.0351 \\
{[0.471]}\end{array}$ & $\begin{array}{l}-0.0031 \\
{[0.950]}\end{array}$ & $\begin{array}{l}0.0301 \\
{[0.520]}\end{array}$ & $\begin{array}{l}0.0064 \\
{[0.895]}\end{array}$ & $\begin{array}{l}0.0179 \\
{[0.715]}\end{array}$ \\
\hline Water Works and Supply & $\begin{array}{l}-0.0603 \\
{[0.374]}\end{array}$ & $\begin{array}{l}-0.0257 \\
{[0.704]}\end{array}$ & $\begin{array}{l}0.0328 \\
{[0.607]}\end{array}$ & $\begin{array}{l}-0.0038 \\
{[0.955]}\end{array}$ & $\begin{array}{l}0.0055 \\
{[0.935]}\end{array}$ & $\begin{array}{l}-0.0324 \\
{[0.638]}\end{array}$ & $\begin{array}{l}0.001 \\
{[0.989]}\end{array}$ & $\begin{array}{l}0.051 \\
{[0.440]}\end{array}$ & $\begin{array}{l}0.0128 \\
{[0.853]}\end{array}$ & $\begin{array}{l}0.0244 \\
{[0.724]}\end{array}$ \\
\hline Construction & $\begin{array}{l}0.0096 \\
{[0.530]}\end{array}$ & $\begin{array}{l}0.0084 \\
{[0.585]}\end{array}$ & $\begin{array}{l}0.0351^{* *} \\
{[0.015]}\end{array}$ & $\begin{array}{l}0.0306^{* *} \\
{[0.047]}\end{array}$ & $\begin{array}{l}0.0263^{*} \\
{[0.089]}\end{array}$ & $\begin{array}{l}0.0559^{* * *} \\
{[0.000]}\end{array}$ & $\begin{array}{l}0.0563^{* * * *} \\
{[0.000]}\end{array}$ & $\begin{array}{l}0.0801^{* * *} \\
{[0.000]}\end{array}$ & $\begin{array}{l}0.0726 * * * \\
{[0.000]}\end{array}$ & $\begin{array}{l}0.0696 * * * \\
{[0.000]}\end{array}$ \\
\hline Wholesale Trade & $\begin{array}{l}-0.1121^{* *} \\
{[0.023]}\end{array}$ & $\begin{array}{l}-0.0960 * \\
{[0.051]}\end{array}$ & $\begin{array}{l}-0.0492 \\
{[0.287]}\end{array}$ & $\begin{array}{l}-0.0805 \\
{[0.101]}\end{array}$ & $\begin{array}{l}-0.0768 \\
{[0.118]}\end{array}$ & $\begin{array}{l}-0.0941 * \\
{[0.060]}\end{array}$ & $\begin{array}{l}-0.0784 \\
{[0.118]}\end{array}$ & $\begin{array}{l}-0.0382 \\
{[0.426]}\end{array}$ & $\begin{array}{l}-0.0688 \\
{[0.170]}\end{array}$ & $\begin{array}{l}-0.064 \\
{[0.201]}\end{array}$ \\
\hline Restaurants and Hotels & $\begin{array}{l}-0.0196 \\
{[0.343]}\end{array}$ & $\begin{array}{l}-0.016 \\
{[0.439]}\end{array}$ & $\begin{array}{l}0.003 \\
{[0.879]}\end{array}$ & $\begin{array}{l}0.0112 \\
{[0.589]}\end{array}$ & $\begin{array}{l}0.0096 \\
{[0.644]}\end{array}$ & $\begin{array}{l}0.0059 \\
{[0.778]}\end{array}$ & $\begin{array}{l}0.009 \\
{[0.668]}\end{array}$ & $\begin{array}{l}0.026 \\
{[0.197]}\end{array}$ & $\begin{array}{l}0.0305 \\
{[0.149]}\end{array}$ & $\begin{array}{l}0.0281 \\
{[0.186]}\end{array}$ \\
\hline Transport and Storage & $\begin{array}{l}-0.0652^{* * *} \\
{[0.000]}\end{array}$ & $\begin{array}{l}-0.0607 * * * \\
{[0.000]}\end{array}$ & $\begin{array}{l}-0.0179 \\
{[0.204]}\end{array}$ & $\begin{array}{l}-0.0437 * * * \\
{[0.004]}\end{array}$ & $\begin{array}{l}-0.0447 * * * \\
{[0.003]}\end{array}$ & $\begin{array}{l}-0.0398^{* * *} \\
{[0.009]}\end{array}$ & $\begin{array}{l}-0.0354 * * \\
{[0.021]}\end{array}$ & $\begin{array}{l}0.0013 \\
{[0.928]}\end{array}$ & $\begin{array}{l}-0.0225 \\
{[0.141]}\end{array}$ & $\begin{array}{l}-0.0234 \\
{[0.127]}\end{array}$ \\
\hline Communication & $\begin{array}{l}-0.1759^{* * *} \\
{[0.001]}\end{array}$ & $\begin{array}{l}-0.1501^{* * * *} \\
{[0.006]}\end{array}$ & $\begin{array}{l}-0.0966 * \\
{[0.061]}\end{array}$ & $\begin{array}{l}-0.1237 * * \\
{[0.024]}\end{array}$ & $\begin{array}{l}-0.1178^{* *} \\
{[0.032]}\end{array}$ & $\begin{array}{l}-0.1018 * \\
{[0.069]}\end{array}$ & $\begin{array}{l}-0.0768 \\
{[0.170]}\end{array}$ & $\begin{array}{l}-0.031 \\
{[0.563]}\end{array}$ & $\begin{array}{l}-0.06 \\
{[0.284]}\end{array}$ & $\begin{array}{l}-0.0526 \\
{[0.348]}\end{array}$ \\
\hline Financial Institutions & $\begin{array}{l}-0.1451^{* * *} \\
{[0.000]}\end{array}$ & $\begin{array}{l}-0.1063^{* * *} \\
{[0.000]}\end{array}$ & $\begin{array}{l}-0.0735^{* * * *} \\
{[0.009]}\end{array}$ & $\begin{array}{l}-0.0959 * * * \\
{[0.001]}\end{array}$ & $\begin{array}{l}-0.0823^{* * * *} \\
{[0.006]}\end{array}$ & $\begin{array}{l}-0.1083^{* * * *} \\
{[0.000]}\end{array}$ & $\begin{array}{l}-0.0686 * * \\
{[0.025]}\end{array}$ & $\begin{array}{l}-0.0404 \\
{[0.168]}\end{array}$ & $\begin{array}{l}-0.0688^{* *} \\
{[0.023]}\end{array}$ & $\begin{array}{l}-0.0506^{*} \\
{[0.098]}\end{array}$ \\
\hline Insurance & $\begin{array}{l}-0.1111 \\
{[0.102]}\end{array}$ & $\begin{array}{l}-0.0758 \\
{[0.271]}\end{array}$ & $\begin{array}{l}-0.0368 \\
{[0.569]}\end{array}$ & $\begin{array}{l}-0.0719 \\
{[0.288]}\end{array}$ & $\begin{array}{l}-0.0571 \\
{[0.405]}\end{array}$ & $\begin{array}{l}-0.1744^{* *} \\
{[0.012]}\end{array}$ & $\begin{array}{l}-0.1370^{*} \\
{[0.050]}\end{array}$ & $\begin{array}{l}-0.1035 \\
{[0.123]}\end{array}$ & $\begin{array}{l}-0.1431^{* *} \\
{[0.038]}\end{array}$ & $\begin{array}{l}-0.1230 * \\
{[0.079]}\end{array}$ \\
\hline Real estate \& Business & $\begin{array}{l}-0.0192 \\
{[0.387]}\end{array}$ & $\begin{array}{l}-0.0048 \\
{[0.831]}\end{array}$ & $\begin{array}{l}0.0255 \\
{[0.226]}\end{array}$ & $\begin{array}{l}0.0053 \\
{[0.810]}\end{array}$ & $\begin{array}{l}0.0086 \\
{[0.701]}\end{array}$ & $\begin{array}{l}0.0233 \\
{[0.304]}\end{array}$ & $\begin{array}{l}0.0351 \\
{[0.125]}\end{array}$ & $\begin{array}{l}0.0612^{* * *} \\
{[0.005]}\end{array}$ & $\begin{array}{l}0.0430^{*} \\
{[0.058]}\end{array}$ & $\begin{array}{l}0.0451^{* *} \\
{[0.048]}\end{array}$ \\
\hline Public Administration & $\begin{array}{l}-0.1120^{* * *} \\
{[0.000]}\end{array}$ & $\begin{array}{l}-0.0846^{* * * *} \\
{[0.000]}\end{array}$ & $\begin{array}{l}-0.0195 \\
{[0.299]}\end{array}$ & $\begin{array}{l}-0.0596 * * * \\
{[0.003]}\end{array}$ & $\begin{array}{l}-0.0530^{* * *} \\
{[0.009]}\end{array}$ & $\begin{array}{l}-0.0241 \\
{[0.224]}\end{array}$ & $\begin{array}{l}0.0012 \\
{[0.953]}\end{array}$ & $\begin{array}{l}0.0568^{* * *} \\
{[0.004]}\end{array}$ & $\begin{array}{l}0.0179 \\
{[0.380]}\end{array}$ & $\begin{array}{l}0.0249 \\
{[0.226]}\end{array}$ \\
\hline Sanity & $\begin{array}{l}0.0429 \\
{[0.527]}\end{array}$ & $\begin{array}{l}0.0795 \\
{[0.242]}\end{array}$ & $\begin{array}{l}0.1384 * * \\
{[0.030]}\end{array}$ & $\begin{array}{l}0.099 \\
{[0.143]}\end{array}$ & $\begin{array}{l}0.1094 \\
{[0.106]}\end{array}$ & $\begin{array}{l}0.1289^{*} \\
{[0.062]}\end{array}$ & $\begin{array}{l}0.1644 * * \\
{[0.017]}\end{array}$ & $\begin{array}{l}0.2147^{* * * *} \\
{[0.001]}\end{array}$ & $\begin{array}{l}0.1739^{* *} \\
{[0.012]}\end{array}$ & $\begin{array}{l}0.1868 * * * \\
{[0.007]}\end{array}$ \\
\hline Social and Community Services & $\begin{array}{l}-0.0750^{* * * *} \\
{[0.000]}\end{array}$ & $\begin{array}{l}-0.0479 * * * \\
{[0.007]}\end{array}$ & $\begin{array}{l}-0.0059 \\
{[0.723]}\end{array}$ & $\begin{array}{l}-0.0263 \\
{[0.139]}\end{array}$ & $\begin{array}{l}-0.0197 \\
{[0.273]}\end{array}$ & $\begin{array}{l}-0.0632^{* * * *} \\
{[0.000]}\end{array}$ & $\begin{array}{l}-0.0373^{* *} \\
{[0.039]}\end{array}$ & $\begin{array}{l}-0.0013 \\
{[0.938]}\end{array}$ & $\begin{array}{l}-0.0241 \\
{[0.182]}\end{array}$ & $\begin{array}{l}-0.0162 \\
{[0.376]}\end{array}$ \\
\hline Recreation and Culture & $\begin{array}{l}-0.0596^{*} \\
{[0.087]}\end{array}$ & $\begin{array}{l}-0.0407 \\
{[0.246]}\end{array}$ & $\begin{array}{l}-0.0187 \\
{[0.571]}\end{array}$ & $\begin{array}{l}-0.0187 \\
{[0.592]}\end{array}$ & $\begin{array}{l}-0.0124 \\
{[0.723]}\end{array}$ & $\begin{array}{l}-0.0608^{*} \\
{[0.086]}\end{array}$ & $\begin{array}{l}-0.0403 \\
{[0.258]}\end{array}$ & $\begin{array}{l}-0.0212 \\
{[0.534]}\end{array}$ & $\begin{array}{l}-0.028 \\
{[0.431]}\end{array}$ & $\begin{array}{l}-0.0192 \\
{[0.592]}\end{array}$ \\
\hline Household and Personal Services & $\begin{array}{l}0.0681^{* * *} \\
{[0.000]}\end{array}$ & $\begin{array}{l}0.0638 * * * \\
{[0.000]}\end{array}$ & $\begin{array}{l}0.0429 * * * \\
{[0.001]}\end{array}$ & $\begin{array}{l}0.0790^{* * * *} \\
{[0.000]}\end{array}$ & $\begin{array}{l}0.0757 * * * \\
{[0.000]}\end{array}$ & $\begin{array}{l}0.0814^{* * *} \\
{[0.000]}\end{array}$ & $\begin{array}{l}0.0777 * * * \\
{[0.000]}\end{array}$ & $\begin{array}{l}0.0605^{* * *} \\
{[0.000]}\end{array}$ & $\begin{array}{l}0.0902 * * * \\
{[0.000]}\end{array}$ & $\begin{array}{l}0.0868^{* * *} \\
{[0.000]}\end{array}$ \\
\hline International Bodies & $\begin{array}{l}0.1997 \\
{[0.422]}\end{array}$ & $\begin{array}{l}0.2438 \\
{[0.326]}\end{array}$ & $\begin{array}{l}0.3106 \\
{[0.183]}\end{array}$ & $\begin{array}{l}0.2602 \\
{[0.294]}\end{array}$ & $\begin{array}{l}0.2734 \\
{[0.270]}\end{array}$ & $\begin{array}{l}0.1292 \\
{[0.610]}\end{array}$ & $\begin{array}{l}0.172 \\
{[0.497]}\end{array}$ & $\begin{array}{l}0.2289 \\
{[0.345]}\end{array}$ & $\begin{array}{l}0.1777 \\
{[0.482]}\end{array}$ & $\begin{array}{l}0.194 \\
{[0.442]}\end{array}$ \\
\hline Family worker & & & & $\begin{array}{l}0.2643 * * \\
{[0.041]}\end{array}$ & $\begin{array}{l}0.2521^{*} \\
{[0.052]}\end{array}$ & & & & $\begin{array}{l}0.2537 * \\
{[0.055]}\end{array}$ & $\begin{array}{l}0.2388^{*} \\
{[0.070]}\end{array}$ \\
\hline Self-employed & & & & $\begin{array}{l}0.1016 * * * \\
{[0.000]}\end{array}$ & $\begin{array}{l}0.0902^{* * *} \\
{[0.000]}\end{array}$ & & & & $\begin{array}{l}0.0814^{* * *} \\
{[0.000]}\end{array}$ & $\begin{array}{l}0.0674 * * * \\
{[0.000]}\end{array}$ \\
\hline Informal & & $\begin{array}{l}0.0590^{* * *} \\
{[0.000]}\end{array}$ & $\begin{array}{l}0.0026 \\
{[0.757]}\end{array}$ & & $\begin{array}{l}0.0273^{* * *} \\
{[0.004]}\end{array}$ & & $\begin{array}{l}0.0570^{* * * *} \\
{[0.000]}\end{array}$ & $\begin{array}{l}0.0092 \\
{[0.289]}\end{array}$ & & $\begin{array}{l}0.0332 * * * \\
{[0.001]}\end{array}$ \\
\hline Paid below minimum wage & & & $\begin{array}{l}0.3889 * * * \\
{[0.000]}\end{array}$ & & & & & $\begin{array}{l}0.3292^{* * *} \\
{[0.000]}\end{array}$ & & \\
\hline $\mathrm{R}^{2}$ & .192 & .196 & .292 & .200 & .201 & .233 & .236 & .299 & .238 & .239 \\
\hline Observations & 13,035 & 12,943 & 12,932 & 13,035 & 12,943 & 13,035 & 12,943 & 12,932 & 13,035 & 12,943 \\
\hline
\end{tabular}


Appendix Table A.3c: Poverty and Household Head Characteristics for Households with Employed Head (bottom 10 and 20\%)

\begin{tabular}{|c|c|c|c|c|c|c|c|c|c|c|}
\hline & \multicolumn{5}{|c|}{ bottom $10 \%$} & \multicolumn{5}{|c|}{ bottom $20 \%$} \\
\hline & (1) & (2) & (3) & (4) & (5) & $\overline{(1)}$ & (2) & (3) & (4) & (5) \\
\hline Agriculture and Hunting & $\begin{array}{l}-0.0335^{*} \\
{[0.053]}\end{array}$ & $\begin{array}{l}-0.0332 * \\
{[0.055]}\end{array}$ & $\begin{array}{l}-0.0148 \\
{[0.356]}\end{array}$ & $\begin{array}{l}0.0056 \\
{[0.745]}\end{array}$ & $\begin{array}{l}0.0005 \\
{[0.979]}\end{array}$ & $\begin{array}{l}-0.0137 \\
{[0.539]}\end{array}$ & $\begin{array}{l}-0.0187 \\
{[0.402]}\end{array}$ & $\begin{array}{l}0.0063 \\
{[0.759]}\end{array}$ & $\begin{array}{l}0.0278 \\
{[0.213]}\end{array}$ & $\begin{array}{l}0.0159 \\
{[0.478]}\end{array}$ \\
\hline Forestry and logging & $\begin{array}{l}-0.1807 \\
{[0.114]}\end{array}$ & $\begin{array}{l}-0.1604 \\
{[0.159]}\end{array}$ & $\begin{array}{l}-0.1209 \\
{[0.250]}\end{array}$ & $\begin{array}{l}-0.1157 \\
{[0.306]}\end{array}$ & $\begin{array}{l}-0.1138 \\
{[0.313]}\end{array}$ & $\begin{array}{l}0.1996 \\
{[0.177]}\end{array}$ & $\begin{array}{l}0.2223 \\
{[0.131]}\end{array}$ & $\begin{array}{l}0.2763 * * \\
{[0.040]}\end{array}$ & $\begin{array}{l}0.2686 * \\
{[0.067]}\end{array}$ & $\begin{array}{l}0.2703^{*} \\
{[0.065]}\end{array}$ \\
\hline Fishing & $\begin{array}{l}0.009 \\
{[0.943]}\end{array}$ & $\begin{array}{l}-0.0034 \\
{[0.978]}\end{array}$ & $\begin{array}{l}0.0013 \\
{[0.991]}\end{array}$ & $\begin{array}{l}-0.0149 \\
{[0.904]}\end{array}$ & $\begin{array}{l}-0.0184 \\
{[0.882]}\end{array}$ & $\begin{array}{l}0.0904 \\
{[0.576]}\end{array}$ & $\begin{array}{l}0.0758 \\
{[0.638]}\end{array}$ & $\begin{array}{l}0.0818 \\
{[0.578]}\end{array}$ & $\begin{array}{l}0.0649 \\
{[0.686]}\end{array}$ & $\begin{array}{l}0.0603 \\
{[0.707]}\end{array}$ \\
\hline Coal Mining & $\begin{array}{l}-0.0808 \\
{[0.198]}\end{array}$ & $\begin{array}{l}-0.0516 \\
{[0.410]}\end{array}$ & $\begin{array}{l}-0.0207 \\
{[0.720]}\end{array}$ & $\begin{array}{l}-0.0262 \\
{[0.673]}\end{array}$ & $\begin{array}{l}-0.0186 \\
{[0.765]}\end{array}$ & $\begin{array}{l}-0.1712^{* *} \\
{[0.035]}\end{array}$ & $\begin{array}{l}-0.1384 * \\
{[0.087]}\end{array}$ & $\begin{array}{l}-0.0963 \\
{[0.192]}\end{array}$ & $\begin{array}{l}-0.1131 \\
{[0.160]}\end{array}$ & $\begin{array}{l}-0.1043 \\
{[0.195]}\end{array}$ \\
\hline Petroleum and Natural Gas & $\begin{array}{l}-0.1043^{* *} \\
{[0.034]}\end{array}$ & $\begin{array}{l}-0.0888 * \\
{[0.069]}\end{array}$ & $\begin{array}{l}-0.0392 \\
{[0.385]}\end{array}$ & $\begin{array}{l}-0.051 \\
{[0.293]}\end{array}$ & $\begin{array}{l}-0.0499 \\
{[0.304]}\end{array}$ & $\begin{array}{l}-0.1138 * \\
{[0.073]}\end{array}$ & $\begin{array}{l}-0.0965 \\
{[0.127]}\end{array}$ & $\begin{array}{l}-0.0286 \\
{[0.620]}\end{array}$ & $\begin{array}{l}-0.0572 \\
{[0.363]}\end{array}$ & $\begin{array}{l}-0.0564 \\
{[0.370]}\end{array}$ \\
\hline Metal Ore Mining & $\begin{array}{l}-0.1607 \\
{[0.417]}\end{array}$ & $\begin{array}{l}-0.1719 \\
{[0.383]}\end{array}$ & $\begin{array}{l}-0.0701 \\
{[0.700]}\end{array}$ & $\begin{array}{l}-0.0867 \\
{[0.658]}\end{array}$ & $\begin{array}{l}-0.1008 \\
{[0.606]}\end{array}$ & $\begin{array}{l}-0.2751 \\
{[0.282]}\end{array}$ & $\begin{array}{l}-0.2884 \\
{[0.258]}\end{array}$ & $\begin{array}{l}-0.1488 \\
{[0.523]}\end{array}$ & $\begin{array}{l}-0.1965 \\
{[0.438]}\end{array}$ & $\begin{array}{l}-0.2151 \\
{[0.396]}\end{array}$ \\
\hline Other Mining & $\begin{array}{l}0.0902 \\
{[0.162]}\end{array}$ & $\begin{array}{l}0.067 \\
{[0.309]}\end{array}$ & $\begin{array}{l}0.0304 \\
{[0.617]}\end{array}$ & $\begin{array}{l}0.1278^{* *} \\
{[0.045]}\end{array}$ & $\begin{array}{l}0.0909 \\
{[0.164]}\end{array}$ & $\begin{array}{l}0.1778^{* *} \\
{[0.033]}\end{array}$ & $\begin{array}{l}0.1694 * * \\
{[0.047]}\end{array}$ & $\begin{array}{l}0.1188 \\
{[0.127]}\end{array}$ & $\begin{array}{l}0.2177^{* * * *} \\
{[0.008]}\end{array}$ & $\begin{array}{l}0.1940^{* *} \\
{[0.022]}\end{array}$ \\
\hline Food & $\begin{array}{l}-0.0638^{* * * *} \\
{[0.000]}\end{array}$ & $\begin{array}{l}-0.0399 * * * \\
{[0.003]}\end{array}$ & $\begin{array}{l}-0.0133 \\
{[0.283]}\end{array}$ & $\begin{array}{l}-0.0143 \\
{[0.288]}\end{array}$ & $\begin{array}{l}-0.0085 \\
{[0.529]}\end{array}$ & $\begin{array}{l}-0.0758^{* * * *} \\
{[0.000]}\end{array}$ & $\begin{array}{l}-0.0485^{* * * *} \\
{[0.005]}\end{array}$ & $\begin{array}{l}-0.0123 \\
{[0.440]}\end{array}$ & $\begin{array}{l}-0.0231 \\
{[0.184]}\end{array}$ & $\begin{array}{l}-0.0161 \\
{[0.358]}\end{array}$ \\
\hline Textile, Apparel, Leather & $\begin{array}{l}-0.0731^{* * *} \\
{[0.000]}\end{array}$ & $\begin{array}{l}-0.0604^{* * * *} \\
{[0.000]}\end{array}$ & $\begin{array}{l}-0.0439 * * * \\
{[0.000]}\end{array}$ & $\begin{array}{l}-0.0381 * * * \\
{[0.000]}\end{array}$ & $\begin{array}{l}-0.0367 * * * \\
{[0.001]}\end{array}$ & $\begin{array}{l}-0.0896^{* * *} \\
{[0.000]}\end{array}$ & $\begin{array}{l}-0.0750^{* * *} \\
{[0.000]}\end{array}$ & $\begin{array}{l}-0.0527^{* * *} \\
{[0.000]}\end{array}$ & $\begin{array}{l}-0.0526^{* * * *} \\
{[0.000]}\end{array}$ & $\begin{array}{l}-0.0506^{* * *} \\
{[0.000]}\end{array}$ \\
\hline Wood & $\begin{array}{l}-0.0549 * * * \\
{[0.002]}\end{array}$ & $\begin{array}{l}-0.0530^{* * * *} \\
{[0.002]}\end{array}$ & $\begin{array}{l}-0.0328^{* *} \\
{[0.040]}\end{array}$ & $\begin{array}{l}-0.0249 \\
{[0.147]}\end{array}$ & $\begin{array}{l}-0.0268 \\
{[0.121]}\end{array}$ & $\begin{array}{l}-0.0725^{* * * *} \\
{[0.001]}\end{array}$ & $\begin{array}{l}-0.0728^{* * * *} \\
{[0.001]}\end{array}$ & $\begin{array}{l}-0.0454^{* *} \\
{[0.027]}\end{array}$ & $\begin{array}{l}-0.0406^{*} \\
{[0.068]}\end{array}$ & $\begin{array}{l}-0.0458^{* *} \\
{[0.041]}\end{array}$ \\
\hline Paper & $\begin{array}{l}-0.0821^{* * *} \\
{[0.000]}\end{array}$ & $\begin{array}{l}-0.0565 * * \\
{[0.016]}\end{array}$ & $\begin{array}{l}-0.0304 \\
{[0.161]}\end{array}$ & $\begin{array}{l}-0.036 \\
{[0.123]}\end{array}$ & $\begin{array}{l}-0.0291 \\
{[0.213]}\end{array}$ & $\begin{array}{l}-0.1294 * * * \\
{[0.000]}\end{array}$ & $\begin{array}{l}-0.1007 * * * \\
{[0.001]}\end{array}$ & $\begin{array}{l}-0.0651^{* *} \\
{[0.019]}\end{array}$ & $\begin{array}{l}-0.0804 * * * \\
{[0.008]}\end{array}$ & $\begin{array}{l}-0.0724 * * \\
{[0.017]}\end{array}$ \\
\hline Chemical & $\begin{array}{l}-0.0574 * * * \\
{[0.002]}\end{array}$ & $\begin{array}{l}-0.0199 \\
{[0.293]}\end{array}$ & $\begin{array}{l}0.0032 \\
{[0.853]}\end{array}$ & $\begin{array}{l}-0.0058 \\
{[0.755]}\end{array}$ & $\begin{array}{l}0.0067 \\
{[0.724]}\end{array}$ & $\begin{array}{l}-0.0628 * * * \\
{[0.009]}\end{array}$ & $\begin{array}{l}-0.0194 \\
{[0.427]}\end{array}$ & $\begin{array}{l}0.0082 \\
{[0.714]}\end{array}$ & $\begin{array}{l}-0.0077 \\
{[0.749]}\end{array}$ & $\begin{array}{l}0.0082 \\
{[0.738]}\end{array}$ \\
\hline Non-Metallic Mineral Products & $\begin{array}{l}-0.0454^{* *} \\
{[0.046]}\end{array}$ & $\begin{array}{l}-0.014 \\
{[0.540]}\end{array}$ & $\begin{array}{l}-0.0064 \\
{[0.762]}\end{array}$ & $\begin{array}{l}0.0077 \\
{[0.733]}\end{array}$ & $\begin{array}{l}0.0171 \\
{[0.453]}\end{array}$ & $\begin{array}{l}-0.0615^{* *} \\
{[0.036]}\end{array}$ & $\begin{array}{l}-0.0254 \\
{[0.389]}\end{array}$ & $\begin{array}{l}-0.0153 \\
{[0.570]}\end{array}$ & $\begin{array}{l}-0.0051 \\
{[0.861]}\end{array}$ & $\begin{array}{l}0.0066 \\
{[0.823]}\end{array}$ \\
\hline Basic Metal Industry & $\begin{array}{l}-0.1153^{* * *} \\
{[0.007]}\end{array}$ & $\begin{array}{l}-0.0894 * * \\
{[0.035]}\end{array}$ & $\begin{array}{l}-0.0624 \\
{[0.111]}\end{array}$ & $\begin{array}{l}-0.0679 \\
{[0.107]}\end{array}$ & $\begin{array}{l}-0.061 \\
{[0.147]}\end{array}$ & $\begin{array}{l}-0.038 \\
{[0.490]}\end{array}$ & $\begin{array}{l}-0.0088 \\
{[0.873]}\end{array}$ & $\begin{array}{l}0.028 \\
{[0.576]}\end{array}$ & $\begin{array}{l}0.0124 \\
{[0.820]}\end{array}$ & $\begin{array}{l}0.0204 \\
{[0.708]}\end{array}$ \\
\hline Machinery and Equipment & $\begin{array}{l}-0.0806^{* * *} \\
{[0.000]}\end{array}$ & $\begin{array}{l}-0.0580^{* * * *} \\
{[0.000]}\end{array}$ & $\begin{array}{l}-0.0264 * \\
{[0.054]}\end{array}$ & $\begin{array}{l}-0.0320 * * \\
{[0.030]}\end{array}$ & $\begin{array}{l}-0.0280^{*} \\
{[0.060]}\end{array}$ & $\begin{array}{l}-0.0781^{* * *} \\
{[0.000]}\end{array}$ & $\begin{array}{l}-0.0514 * * * \\
{[0.007]}\end{array}$ & $\begin{array}{l}-0.0083 \\
{[0.635]}\end{array}$ & $\begin{array}{l}-0.0264 \\
{[0.167]}\end{array}$ & $\begin{array}{l}-0.0205 \\
{[0.288]}\end{array}$ \\
\hline Other Manufacturing & $\begin{array}{l}-0.0466 \\
{[0.164]}\end{array}$ & $\begin{array}{l}-0.0437 \\
{[0.189]}\end{array}$ & $\begin{array}{l}-0.0336 \\
{[0.274]}\end{array}$ & $\begin{array}{l}-0.0395 \\
{[0.231]}\end{array}$ & $\begin{array}{l}-0.039 \\
{[0.236]}\end{array}$ & $\begin{array}{l}-0.1001^{* *} \\
{[0.020]}\end{array}$ & $\begin{array}{l}-0.0970 * * \\
{[0.024]}\end{array}$ & $\begin{array}{l}-0.0833^{* *} \\
{[0.034]}\end{array}$ & $\begin{array}{l}-0.0926^{* *} \\
{[0.030]}\end{array}$ & $\begin{array}{l}-0.0923^{* *} \\
{[0.031]}\end{array}$ \\
\hline Electricity, Gas, Steam & $\begin{array}{l}-0.0821^{* * *} \\
{[0.008]}\end{array}$ & $\begin{array}{l}-0.0451 \\
{[0.147]}\end{array}$ & $\begin{array}{l}-0.0172 \\
{[0.549]}\end{array}$ & $\begin{array}{l}-0.0267 \\
{[0.386]}\end{array}$ & $\begin{array}{l}-0.0154 \\
{[0.619]}\end{array}$ & $\begin{array}{l}-0.0716^{*} \\
{[0.074]}\end{array}$ & $\begin{array}{l}-0.03 \\
{[0.455]}\end{array}$ & $\begin{array}{l}0.008 \\
{[0.826]}\end{array}$ & $\begin{array}{l}-0.0128 \\
{[0.749]}\end{array}$ & $\begin{array}{l}0.0007 \\
{[0.986]}\end{array}$ \\
\hline Water Works and Supply & $\begin{array}{l}-0.0602 \\
{[0.172]}\end{array}$ & $\begin{array}{l}-0.0217 \\
{[0.622]}\end{array}$ & $\begin{array}{l}0.0205 \\
{[0.613]}\end{array}$ & $\begin{array}{l}0.0003 \\
{[0.995]}\end{array}$ & $\begin{array}{l}0.0116 \\
{[0.791]}\end{array}$ & $\begin{array}{l}-0.0805 \\
{[0.157]}\end{array}$ & $\begin{array}{l}-0.0371 \\
{[0.513]}\end{array}$ & $\begin{array}{l}0.0206 \\
{[0.691]}\end{array}$ & $\begin{array}{l}-0.0163 \\
{[0.773]}\end{array}$ & $\begin{array}{l}-0.0029 \\
{[0.960]}\end{array}$ \\
\hline Construction & $\begin{array}{l}-0.0516^{* * *} \\
{[0.000]}\end{array}$ & $\begin{array}{l}-0.0516^{* * * *} \\
{[0.000]}\end{array}$ & $\begin{array}{l}-0.0329 * * * \\
{[0.000]}\end{array}$ & $\begin{array}{l}-0.0293 * * * \\
{[0.003]}\end{array}$ & $\begin{array}{l}-0.0328 * * * \\
{[0.001]}\end{array}$ & $\begin{array}{l}-0.0329^{* *} \\
{[0.011]}\end{array}$ & $\begin{array}{l}-0.0322 * * \\
{[0.012]}\end{array}$ & $\begin{array}{l}-0.0057 \\
{[0.629]}\end{array}$ & $\begin{array}{l}-0.0091 \\
{[0.478]}\end{array}$ & $\begin{array}{l}-0.0126 \\
{[0.327]}\end{array}$ \\
\hline Wholesale Trade & $\begin{array}{l}-0.0767^{* *} \\
{[0.017]}\end{array}$ & $\begin{array}{l}-0.0586^{*} \\
{[0.066]}\end{array}$ & $\begin{array}{l}-0.0247 \\
{[0.401]}\end{array}$ & $\begin{array}{l}-0.0428 \\
{[0.176]}\end{array}$ & $\begin{array}{l}-0.0381 \\
{[0.228]}\end{array}$ & $\begin{array}{l}-0.1043^{* *} \\
{[0.012]}\end{array}$ & $\begin{array}{l}-0.0840 * * \\
{[0.042]}\end{array}$ & $\begin{array}{l}-0.0378 \\
{[0.315]}\end{array}$ & $\begin{array}{l}-0.0683 * \\
{[0.096]}\end{array}$ & $\begin{array}{l}-0.063 \\
{[0.125]}\end{array}$ \\
\hline Restaurants and Hotels & $\begin{array}{l}-0.0256^{*} \\
{[0.057]}\end{array}$ & $\begin{array}{l}-0.0223 * \\
{[0.095]}\end{array}$ & $\begin{array}{l}-0.0084 \\
{[0.495]}\end{array}$ & $\begin{array}{l}0.0072 \\
{[0.590]}\end{array}$ & $\begin{array}{l}0.0047 \\
{[0.725]}\end{array}$ & $\begin{array}{l}-0.0357^{* *} \\
{[0.039]}\end{array}$ & $\begin{array}{l}-0.0321 * \\
{[0.064]}\end{array}$ & $\begin{array}{l}-0.0125 \\
{[0.431]}\end{array}$ & $\begin{array}{l}-0.0007 \\
{[0.968]}\end{array}$ & $\begin{array}{l}-0.004 \\
{[0.816]}\end{array}$ \\
\hline Transport and Storage & $\begin{array}{l}-0.0535^{* * *} \\
{[0.000]}\end{array}$ & $\begin{array}{l}-0.0471^{* * * *} \\
{[0.000]}\end{array}$ & $\begin{array}{l}-0.0161 * \\
{[0.073]}\end{array}$ & $\begin{array}{l}-0.0305 * * * \\
{[0.002]}\end{array}$ & $\begin{array}{l}-0.0301^{* * * *} \\
{[0.002]}\end{array}$ & $\begin{array}{l}-0.0739 * * * \\
{[0.000]}\end{array}$ & $\begin{array}{l}-0.0671 * * * \\
{[0.000]}\end{array}$ & $\begin{array}{l}-0.0249 * * \\
{[0.031]}\end{array}$ & $\begin{array}{l}-0.0494 * * * \\
{[0.000]}\end{array}$ & $\begin{array}{l}-0.0497 * * * \\
{[0.000]}\end{array}$ \\
\hline Communication & $\begin{array}{l}-0.0986 * * * \\
{[0.006]}\end{array}$ & $\begin{array}{l}-0.0699 * * \\
{[0.050]}\end{array}$ & $\begin{array}{l}-0.0313 \\
{[0.342]}\end{array}$ & $\begin{array}{l}-0.0427 \\
{[0.227]}\end{array}$ & $\begin{array}{l}-0.0355 \\
{[0.316]}\end{array}$ & $\begin{array}{l}-0.1203^{* * *} \\
{[0.009]}\end{array}$ & $\begin{array}{l}-0.0879 * \\
{[0.056]}\end{array}$ & $\begin{array}{l}-0.0352 \\
{[0.403]}\end{array}$ & $\begin{array}{l}-0.0609 \\
{[0.184]}\end{array}$ & $\begin{array}{l}-0.0525 \\
{[0.253]}\end{array}$ \\
\hline Financial Institutions & $\begin{array}{l}-0.0801^{* * *} \\
{[0.000]}\end{array}$ & $\begin{array}{l}-0.0388 * * \\
{[0.046]}\end{array}$ & $\begin{array}{l}-0.0149 \\
{[0.405]}\end{array}$ & $\begin{array}{l}-0.0273 \\
{[0.152]}\end{array}$ & $\begin{array}{l}-0.0133 \\
{[0.493]}\end{array}$ & $\begin{array}{l}-0.1236 * * * \\
{[0.000]}\end{array}$ & $\begin{array}{l}-0.0766 * * * \\
{[0.002]}\end{array}$ & $\begin{array}{l}-0.0442^{*} \\
{[0.054]}\end{array}$ & $\begin{array}{l}-0.0676 * * * \\
{[0.006]}\end{array}$ & $\begin{array}{l}-0.0503^{* *} \\
{[0.045]}\end{array}$ \\
\hline Insurance & $\begin{array}{l}-0.0828 * \\
{[0.061]}\end{array}$ & $\begin{array}{l}-0.0497 \\
{[0.265]}\end{array}$ & $\begin{array}{l}-0.0214 \\
{[0.603]}\end{array}$ & $\begin{array}{l}-0.0409 \\
{[0.348]}\end{array}$ & $\begin{array}{l}-0.0298 \\
{[0.500]}\end{array}$ & $\begin{array}{l}-0.1292^{* *} \\
{[0.023]}\end{array}$ & $\begin{array}{l}-0.091 \\
{[0.114]}\end{array}$ & $\begin{array}{l}-0.0524 \\
{[0.319]}\end{array}$ & $\begin{array}{l}-0.0847 \\
{[0.135]}\end{array}$ & $\begin{array}{l}-0.0705 \\
{[0.219]}\end{array}$ \\
\hline Real estate \& Business & $\begin{array}{l}-0.0754^{* * * *} \\
{[0.000]}\end{array}$ & $\begin{array}{l}-0.0580^{* * * *} \\
{[0.000]}\end{array}$ & $\begin{array}{l}-0.0359 * * * \\
{[0.008]}\end{array}$ & $\begin{array}{l}-0.0491 * * * \\
{[0.001]}\end{array}$ & $\begin{array}{l}-0.0437^{* * * *} \\
{[0.003]}\end{array}$ & $\begin{array}{l}-0.0737 * * * \\
{[0.000]}\end{array}$ & $\begin{array}{l}-0.0533^{* * * *} \\
{[0.005]}\end{array}$ & $\begin{array}{l}-0.0233 \\
{[0.176]}\end{array}$ & $\begin{array}{l}-0.0458 * * \\
{[0.014]}\end{array}$ & $\begin{array}{l}-0.0386^{* *} \\
{[0.040]}\end{array}$ \\
\hline Public Administration & $\begin{array}{l}-0.0999 * * * \\
{[0.000]}\end{array}$ & $\begin{array}{l}-0.0694^{* * * *} \\
{[0.000]}\end{array}$ & $\begin{array}{l}-0.0225^{*} \\
{[0.059]}\end{array}$ & $\begin{array}{l}-0.0439 * * * \\
{[0.001]}\end{array}$ & $\begin{array}{l}-0.0359 * * * \\
{[0.006]}\end{array}$ & $\begin{array}{l}-0.1242^{* * *} \\
{[0.000]}\end{array}$ & $\begin{array}{l}-0.0899 * * * \\
{[0.000]}\end{array}$ & $\begin{array}{l}-0.0258^{*} \\
{[0.091]}\end{array}$ & $\begin{array}{l}-0.0647^{* * *} \\
{[0.000]}\end{array}$ & $\begin{array}{l}-0.0553^{* * *} \\
{[0.001]}\end{array}$ \\
\hline Sanity & $\begin{array}{l}-0.1182 * * * \\
{[0.007]}\end{array}$ & $\begin{array}{l}-0.0775 * \\
{[0.078]}\end{array}$ & $\begin{array}{l}-0.0351 \\
{[0.387]}\end{array}$ & $\begin{array}{l}-0.0581 \\
{[0.183]}\end{array}$ & $\begin{array}{l}-0.0457 \\
{[0.295]}\end{array}$ & $\begin{array}{l}-0.0509 \\
{[0.371]}\end{array}$ & $\begin{array}{l}-0.005 \\
{[0.930]}\end{array}$ & $\begin{array}{l}0.0531 \\
{[0.306]}\end{array}$ & $\begin{array}{l}0.013 \\
{[0.819]}\end{array}$ & $\begin{array}{l}0.0278 \\
{[0.623]}\end{array}$ \\
\hline Social and Community Services & $\begin{array}{l}-0.0738^{* * * *} \\
{[0.000]}\end{array}$ & $\begin{array}{l}-0.0428 * * * \\
{[0.000]}\end{array}$ & $\begin{array}{l}-0.0124 \\
{[0.245]}\end{array}$ & $\begin{array}{l}-0.0216 * \\
{[0.059]}\end{array}$ & $\begin{array}{l}-0.0128 \\
{[0.269]}\end{array}$ & $\begin{array}{l}-0.0842^{* * * *} \\
{[0.000]}\end{array}$ & $\begin{array}{l}-0.0491 * * * \\
{[0.001]}\end{array}$ & $\begin{array}{l}-0.0077 \\
{[0.573]}\end{array}$ & $\begin{array}{l}-0.0287^{*} \\
{[0.053]}\end{array}$ & $\begin{array}{l}-0.0182 \\
{[0.227]}\end{array}$ \\
\hline Recreation and Culture & $\begin{array}{l}-0.0587 * * * \\
{[0.010]}\end{array}$ & $\begin{array}{l}-0.0414 * \\
{[0.068]}\end{array}$ & $\begin{array}{l}-0.0253 \\
{[0.228]}\end{array}$ & $\begin{array}{l}-0.0149 \\
{[0.508]}\end{array}$ & $\begin{array}{l}-0.0113 \\
{[0.616]}\end{array}$ & $\begin{array}{l}-0.0690^{* *} \\
{[0.018]}\end{array}$ & $\begin{array}{l}-0.0486 * \\
{[0.098]}\end{array}$ & $\begin{array}{l}-0.0268 \\
{[0.317]}\end{array}$ & $\begin{array}{l}-0.0225 \\
{[0.441]}\end{array}$ & $\begin{array}{l}-0.0177 \\
{[0.547]}\end{array}$ \\
\hline Household and Personal Services & $\begin{array}{l}0.0154^{*} \\
{[0.099]}\end{array}$ & $\begin{array}{l}0.0107 \\
{[0.249]}\end{array}$ & $\begin{array}{l}-0.0037 \\
{[0.665]}\end{array}$ & $\begin{array}{l}0.0272 * * * \\
{[0.003]}\end{array}$ & $\begin{array}{l}0.0236^{* *} \\
{[0.011]}\end{array}$ & $\begin{array}{l}0.0527^{* * *} \\
{[0.000]}\end{array}$ & $\begin{array}{l}0.0469 * * * \\
{[0.000]}\end{array}$ & $\begin{array}{l}0.0267 * * \\
{[0.015]}\end{array}$ & $\begin{array}{l}0.0651^{* * * *} \\
{[0.000]}\end{array}$ & $\begin{array}{l}0.0601^{* * *} \\
{[0.000]}\end{array}$ \\
\hline International Bodies & $\begin{array}{l}-0.0716 \\
{[0.658]}\end{array}$ & $\begin{array}{l}-0.0224 \\
{[0.890]}\end{array}$ & $\begin{array}{l}0.0257 \\
{[0.863]}\end{array}$ & $\begin{array}{l}-0.007 \\
{[0.965]}\end{array}$ & $\begin{array}{l}0.009 \\
{[0.955]}\end{array}$ & $\begin{array}{l}-0.0959 \\
{[0.646]}\end{array}$ & $\begin{array}{l}-0.0401 \\
{[0.847]}\end{array}$ & $\begin{array}{l}0.0258 \\
{[0.892]}\end{array}$ & $\begin{array}{l}-0.0271 \\
{[0.896]}\end{array}$ & $\begin{array}{l}-0.0077 \\
{[0.970]}\end{array}$ \\
\hline Family worker & & & & $\begin{array}{l}0.3476^{* * * *} \\
{[0.000]}\end{array}$ & $\begin{array}{l}0.3338^{* * *} \\
{[0.000]}\end{array}$ & & & & $\begin{array}{l}0.3113^{* * * *} \\
{[0.004]}\end{array}$ & $\begin{array}{l}0.2933^{* * *} \\
{[0.007]}\end{array}$ \\
\hline Self-employed & & & & $\begin{array}{l}0.1086^{* * * *} \\
{[0.000]}\end{array}$ & $\begin{array}{l}0.0958^{* * *} \\
{[0.000]}\end{array}$ & & & & $\begin{array}{l}0.1156^{* * *} \\
{[0.000]}\end{array}$ & $\begin{array}{l}0.0989 * * * \\
{[0.000]}\end{array}$ \\
\hline Informal & & $\begin{array}{l}0.0656 * * * \\
{[0.000]}\end{array}$ & $\begin{array}{l}0.0253^{* * *} \\
{[0.000]}\end{array}$ & & $\begin{array}{l}0.0318^{* * *} \\
{[0.000]}\end{array}$ & & $\begin{array}{l}0.0744^{* * * *} \\
{[0.000]}\end{array}$ & $\begin{array}{l}0.0189 * * * \\
{[0.006]}\end{array}$ & & $\begin{array}{l}0.0396 * * * \\
{[0.000]}\end{array}$ \\
\hline $\mathrm{Pa}$ & & & $\begin{array}{l}0.2779 * * * \\
{[0.000]}\end{array}$ & & & & & $\begin{array}{l}0.3822 * * * \\
{[0.000]}\end{array}$ & & \\
\hline n & .082 & .092 & .225 & .106 & .108 & .129 & .137 & .279 & .144 & $\begin{array}{l}.146 \\
12.943\end{array}$ \\
\hline Observations & 13,035 & 12,943 & 12,932 & 13,035 & 12,943 & 13,035 & 12,943 & 12,932 & 13,035 & 12,943 \\
\hline
\end{tabular}

